\title{
Reconnaissance of the
}

\section{Geology and Ground}

Water of the Khorat

\section{Plateau, Thailand}

By P. E. LAMOREAUX, JUMCHET CHARALJAVANAPHET, NITIPAT JALICHAN, PHONG PHAN NA CHIENGMAI, DIN BUNNAG, ADUL THAVISRI, and CHUMPHON RAKPRATHUM

GEOLOGICAL SURVEY WATER-SUPPLY PAPER 1429

Prepared in cooperation with the Royal Department of Mines, Ministry of Industry; Royal Irrigation Department, Ministry of Agriculture; and the Department of Health, Ministry of Public

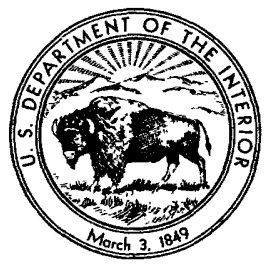
Health; and under the auspices of the United States Operations Mission to Thailand 


\title{
UNITED STATES DEPARTMENT OF THE INTERIOR
}

FRED A. SEATON, Secretary

\author{
GEOLOGIGAL SURVEY
}

Thomas B. Nola n, Director 


\section{CONTENTS}

Abstract

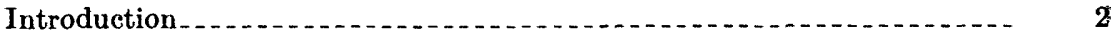

Purpose and scope

Location and extent . . . .

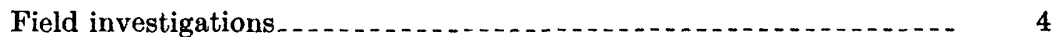

Previous investigations.........

Acknowledgments . . . . . 6

Geography, by Adul Thavisri. 6

Political division

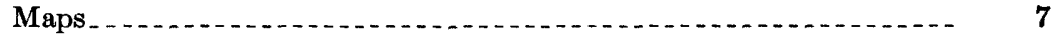

Topography and drainage.

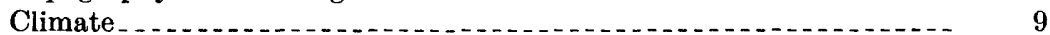

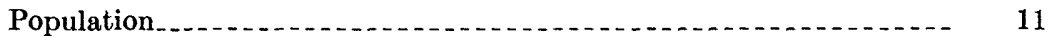

Transportation. . . . . . 12

Geology, by Nitipat Jalichan, Din Bunnag, and P. E. LaMoreaux . . . . 12

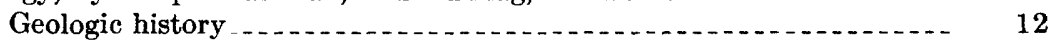

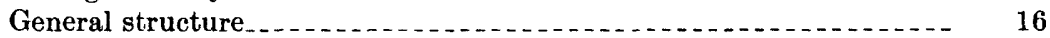

Khorat and Sakon Nakhon basins . . .

Phu Phan range.......... 16

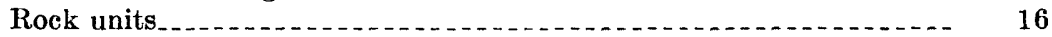

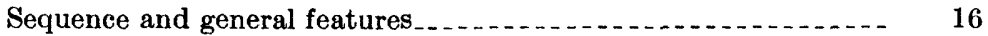

Kanchanaburi series(Silurian?, Devonian?, and early Carboniferous)_ $\quad 18$

Rat Buri limestone (Carboniferous? and Permian) $\ldots . . . . . . . . .18$

Khorat series (Triassic) _. . . .

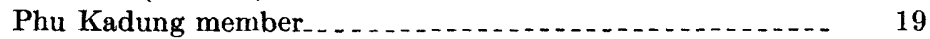

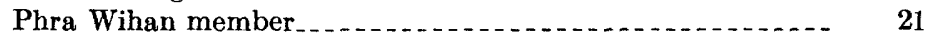

Phu Phan member..................................... 23

Beds of Jurassic and Cretaceous (?) age ................. 24

Tertiary igneous rocks. . . . . .

Quaternary terrace deposits and alluvium ................... 27

Ground water, by P. E. LaMoreaux, Jumchet Charaljavanaphet, and

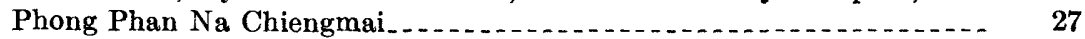

Source and occurrence

Water table

Artesian conditions. . . .

Recharge............... 30

Recovery of ground water. 36

Dug wells . . .

Bored wells .....

Drilled wells . .

Springs. .............

$\begin{array}{ll}\text { Potential recovery of ground water in the Khorat Plateau. . . . . . } & 37\end{array}$

Water from soil and weathered bedrock . . .

Water from alluvium . . .

Water from dipping sandstone beds . . 
Ground water, by P. E. LaMoreaux, Jumchet Charaljavanaphet, and Phong Phan Na Chiengmai-Continued

Quality of water.... 40

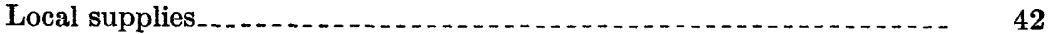

Khon Kaen.................. 43

Udon Thani............ 43

Nong Khai _....... 44

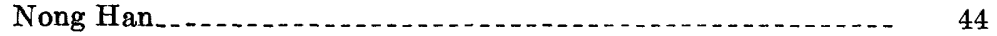

Sakon Nakhon

Amphoes Nakhon Phanom, Mukdahan, and That Phanom _... 45

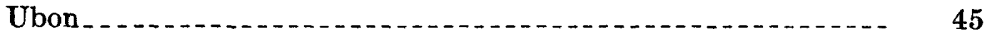

Road from Ubon to Ban Phai.

Mahasarakham

Roi Et. .

Sisaket._. 47

Surin

Buriram ................... 48

Ubon to Khorat.

Summary

Selected references...

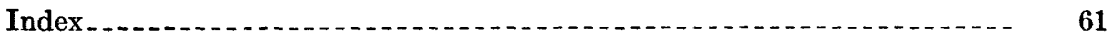

\section{ILLUSTRATIONS}

[Plates 1 to 4 are in pocket]

Plate 1. Diagrammatic sketch of the physiographic provinces of Thailand.

2. Map of the Khorat Plateau showing location of wells.

3. Outline maps of municipalities in the Khorat Plateau showing location of wells.

4. Geologic reconnaissance map of the Khorat Plateau.

5. A, Khorat escarpment from kilometer 45 on Pakthongchai-

Page Kabinburi road. $B$, Rat Buri limestone exposed at Pha Nok Khao on Khon Kaen-Loei road .............. facing 10

6. Phu Kadung member of Khorat series exposed on Nong Bua Lamphu road west of Udon Thani................ facing 11

7. A, Phra Wihan member of the Khorat series exposed near kilometer 40 on the Udon Thani-Loei road. B, Phu Phan member of the Khorat series exposed near kilometer 55 on the Khorat-Kabinburi road _...

8. Royal well at Wat That Phanom ................. facing 27

9. $A$, Well at Wat Makham Thao near Khorat, bored by the Royal Department of Health. $B$, Screen used in construction of shallow bored wells. 
FIgure 1. Index map of Thailand showing changwats (counties) in the Page Khorat Plateau. . . . .

2. Graphs showing average monthly rainfall at Ubon, Sisaket, Roi Et, Khon Kaen, and Kalasin

3. Graphs showing average monthly rainfall for Bua Yai, Surin, Khorat, Nakhon Phanom, Nong Khai, and Udon Thani and average monthly evaporation at Khorat and Udon Thani--

4. Generalized geologic section in Khorat Plateau from Phanom Dang Raek escarpment through Khorat to Nakhon

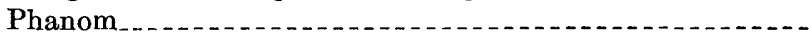

5. Generalized geologic section at Phu Kadung

6. Generalized geologic section at Phra Wihan

7. Schematic diagram showing artesian and water-table condi-

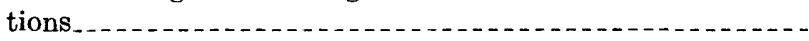

8. Map showing outcrop of Triassic rocks and distribution of rainfall during January in the Khorat Plateau. . . . . . . . . .

9. Map showing distribution of rainfall during April in the Khorat

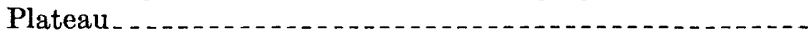

10. Map showing distribution of rainfall during July in the Khorat

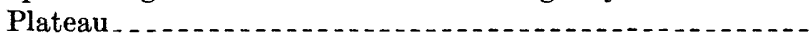

11. Map showing distribution of rainfall during October in the Khorat Plateau

\section{TABLES}

TABLE 1. Generalized geologic table of rocks in the Khorat Plateau and their probable water-bearing characteristics.......-..-.

2. Records of wells in the Khorat Plateau 


\title{
REGONNAISSANGE OF THE GEOLOGY AND GROUND WATER OF THE KHORAT PLATEAU, THAILAND
}

\author{
By P. E. LaMoreaux, Jumghet Charaljavanaphet, Nitipat \\ Jalighon, Phong Phan Na Chiengmai, Din Bunnag, Adul \\ Thavisri, and Chumphon Rakprathum
}

\begin{abstract}
ABS'TRACT
Fieldwork for a geologic reconnaissance and ground-water investigation to determine the ground-water resources of the Khorat Plateau, with especial reference to the development of supplies of ground water for public and domestic use and the location of potentlal sources of water for proposed industrial and irrigation use, was made from October 27 to November 20, 1954.

The Khorat Plateau, one of the principal physiographic features of Thailand, is a shallow basin-shaped area tilted slightly to the southeast. It is bounded on the north and east by the Mae Nam Khong (Mekong River), on the west by the Thiu Khao Phetchabun, and on the south by the outward-facing Phanom Dang Raek escarpment. In general, the central part of the plateau is a monotonous plain broken by gently rolling hills; the altitude is about 150 meters, but in some places along the Phanom Dang Raek escarpment the altitude is nearly
\end{abstract} 700 meters above sea level.

The plateau is made up mainly of sandstone and shale beds of Triassic age underlain by shale, sandstone, and limestone of Paleozoic age and overlain by sandstone, sandy shale, and sand of Jurassic age and possibly by some beds of Cretaceous age. The sedimentary rocks in the southern part of the plateau near Surin, Sisaket, and Buriram are interbedded with and intruded by basalt flows and dikes probably of Tertiary age. Deposits of alluvial silt, clay, sand, and gravel of Quaternary age occur throughout the area beneath flood plains, stream channels, and terraces.

The Khorat Plateau ls divided into three structural features: the Phu Phan range of hills, created by a series of gentle folds in rocks of Triassic age near the end of the Triassic period, and the Sakon Nakhon basin and the Khorat basin, depressions formed on opposite sides of the range.

Three potential sources of ground water in the area are from the soil and bedrock throughout the area, which will supply water adequate for domestic needs to shallow dug, bored, or drilled wells generally not exceeding 100 feet in depth; alluvial deposits of sand and gravel near permanent streams in the area, which will supply water adequate for domestic, municipal, and limited industrial and agricultural needs to shallow dug or drilled wells generally not exceeding 100 feet in depth; and dipping sandstone beds, which will supply water under artesian pressure to drilled wells exceeding 100 feet in depth.

Along with future exploration for ground-water resources and their development, there is need for a systematic study of ground water and a program for promulgating reports to aid future development of ground-water supplies in the area. 


\section{INTRODUCTION}

\section{PURPOSE AND SCOPE}

The welfare of the rural, village, and industrial segments of the population of the Khorat Plateau in northeastern Thailand (see fig. 1) could be greatly enhanced by the development of an adequate supply

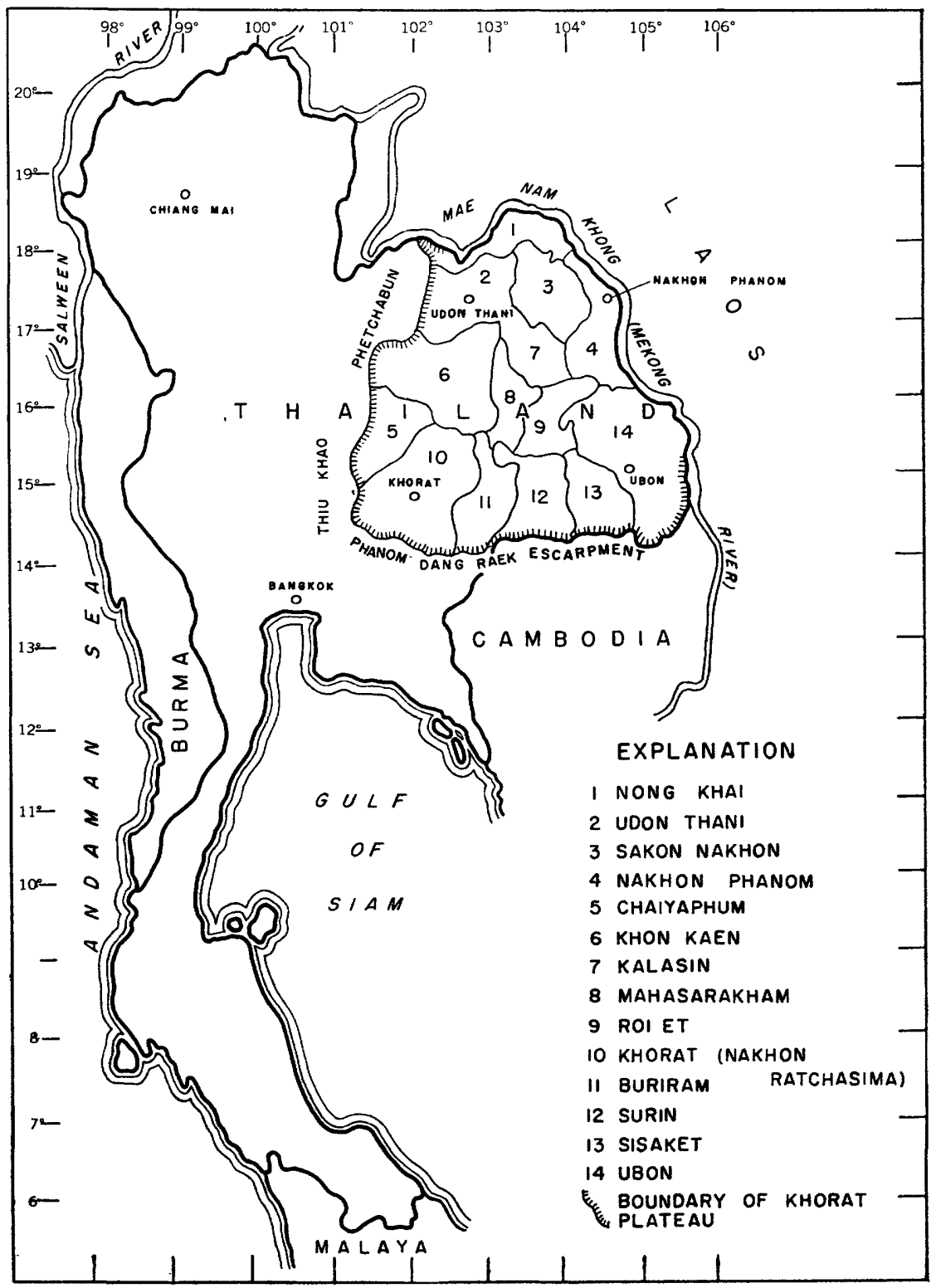

Froure 1.-Index map of Thalland showing changwats (counties) in the Khorat Plateau. 
of potable water for domestic use and additional water for stock. Greater stability of the agricultural economy of the area would result if water for irrigation also were available during the "dry" period from November until late April. Additional water for irrigation would allow more efficient use of suitable marginal farm lands which now are either ineffectually used or lying idle for lack of water. Proposed and existing private and government-sponsored industrial developments in the area, and the installations of the railroad along its right-of-way, require new or supplemental water supplies. Additional water is needed also for military use.

Problems of health and sanitation are an important aspect of watersupply development. At each large village, information was requested from the local public-health authorities on the average age at death, childbirth fatality rate, and predominant diseases. The principal reported diseases are malaria, tuberculosis, influenza, and intestinal diseases. Of these, the chronic intestinal infections are directly related to water supply. At present, the principal sources of water in the area are klongs (canals), ponds, either natural or artificial, and dug and bored wells.

Different phases of these water problems and needs were recognized by several Thai government agencies and coordinating officers of the United States Operations Mission (USOM), and initial planning was done toward the development of supplies of ground water for rural, village, and railroad use and for irrigation. In this planning the need became evident for coordination of manpower and equipment, economic administration, and systematic and complete collection and distribution of information about ground water.

A reconnaissance of the geology and ground-water resources of the Khorat Plateau, the results of which are given in this report, was undertaken on behalf of the following agencies of the Royal Government of Thailand: Ministry of Industry, Geological Survey of the Royal Department of Mines; Ministry of Agriculture, Royal Irrigation Department; Ministry of Interior, Municipal and Public Works Department; Ministry of Public Health, Department of Public Health; and the Thai State Railways Organization. Coordinating with these Thai agencies are the offices of Industry, Public Health, and Agriculture of the United States Operations Mission to Thailand (USOM). A conference in June 1954 of Scientific Technical and Economic Mission, STEM (USOM after July 1, 1954), and Thai officials with T. E. Eakin of the United States Geological Survey resulted in the assignment of P. E. LaMoreaux for a 3-month period to collect and review available geologic and hydrologic data, make a reconnaissance study of the geology and ground water of the Khorat Plateau, begin training a team comprising three Thai geologists, one 
Thai irrigation engineer, and one Thai sanitary engineer in the basic methods of ground-water investigation, and plan the organization necessary for a continuing program of collecting and recording basic ground-water data to aid test drilling and development of supplies of ground water in the area.

This report is to be published in a Thai edition as well as in this English edition. Because it will be the first report of its kind to be published in Thailand, it contains a slightly longer discussion of the fundamentals of ground-water hydrology than would normally be considered necessary in a report of its scope.

\section{LOCATION AND EXTENT}

The Kingdom of Thailand, on the Indochina peninsula of southeast Asia, is bounded on the north by the Shan State and Laos, which in turn are bounded on the north by China. West of Thailand are Burma and the Andaman Sea; on the south, the Gulf of Siam and the Federation of Malaya; on the southeast Cambodia; and on the east, Laos (see fig. 1).

The area of Thailand is about 513,500 square kilometers. Its maximum length is 1,600 kilometers and its maximum width, 770 kilometers. It extends from $6^{\circ}$ to $20^{\circ}$ north latitude and from $98^{\circ}$ to $106^{\circ}$ west longitude.

Thailand may be divided physiographically into five provinces: the Northwest Highlands, the Chao Phraya Plain, the Chanthaburi, the Peninsula, and the Khorat Plateau. This report covers the Khorat Plateau, in the northeastern part of the country (see fig. 1, pl. 1).

The Khorat Plateau comprises an area of about 155,000 square kilometers or 60,000 square miles. It is a relatively flat, saucershaped upland having an average altitude of about 150 meters. The plateau is gently undulating in the interior; however, it is bounded on the southeast, south, and west by a steep, outward-facing escarpment. The northern and eastern boundary is the Mae Nam Khong which separates Thailand from Laos. The plateau is about 450 kilometers from east to west and also from north to south (see fig. 1, pl. 1).

\section{FIELD INVESTIGATIONS}

With the arrival of P. E. LaMoreaux in Bangkok, October 14, 1954, a field party was organized that included the following personnel in addition to LaMoreaux: Jumchet Charaljavanaphet, Phong Phan $\mathrm{Na}$ Chiengmai, and Din Bunnag, geologists of the Geological Survey of Thailand; Adul Thavisri, irrigation engineer of the Royal Irrigation Department; and Chumphon Rakprathum, sanitary engineer of the Department of Public Health. The party traveled more than 
6,000 kilometers on the principal and secondary roads in the area, collected data on 158 representative water wells and springs, and revisited most of the geologic exposures studied during an earlier reconnaissance (Jalichan and Bunnag, 1954) of the area. Fieldwork was completed on November 20, 1954.

A reconnaissance of the geology of the area by Nitipat Jalichan and Din Bunnag was made from March 14 to May 22, 1953, as a part of a cooperative program between the Geological Survey of Thailand and STEM. The geology as described by Jalichan and Bunnag is the basis for the geology in this report, and Din Bunnag was assigned to the field party to aid in the review of the geology of the area and to help in the collection of supplemental data.

\section{PREVIOUS INVESTIGATIONS}

Early geologic work in Thailand by foreigners consisted chiefly of studies relating to mineral exploration. Some of the earlier studies, like that of Halt Hallet (1890), were directed at finding the most economical railroad routes. The results of an earlier reconnaissance geologic study in the Khorat Plateau are given in a report, available only in manuscript form, by Wallace Lee, an American geologist, which is entitled "A reconnaissance geological report of the Khorat region" (1923).

The Geological Survey of the Royal Department of Mines was organized in 1941 but did not become completely active until after World War II, in 1946. Geological investigations have resulted in several reports on geology and mineral resources, some published and others in manuscript form. These reports have been used as references for this report. An excellent reference was compiled by four geologists of the Thai Geological Survey who teamed with three geologists of the U. S. Geological Survey to produce the report "Geologic reconnaissance of the mineral deposits of Thailand" (Brown, Buravas, Charaljavanaphet, Jalichandra, Johnston, Sresthaputra, and Taylor, 1951). That report included considerable information on the Khorat Plateau. Since 1951 two reconnaissance geologic reports on the area have been prepared and are in manuscript form (Jalichan and Bunnag, 1954, and Kaewphaithoon and Viraburus, 1953).

The first report on ground water in the area, "Underground watera possible solution to the water-supply problem in northeastern Thailand," was given by Jalichan at the Science Conference in Bangkok in 1953. The possibility of obtaining artesian water from the dipping sandstone beds in the plateau was noted.

Other important sources of data for this report are the logs of two wells that were drilled at Khorat by the Public Works Department, logs of wells at Khorat and Bua Yai drilled by the Thai Railways 
Organization, and the many records of shallow wells bored by the Department of Health.

\section{ACKNOWLEDGMENTS}

The splendid progress in organization, fieldwork, and completion of this report is evidence of the fine cooperation in spirit and action of all personnel participating in this study. Many members of the four Thai departments and USOM provided immediate specific assistance upon request and thereby expedited the final results.

Specific acknowledgment is given to His Excellency Lt. Gen. Banyat Devahastin, Minister of Industry; to Director-General Pathom Gajaseni of the Royal Department of Mines, and to Vija Sethaput, Chief Geologist, Geological Survey of Thailand, who provided funds and equipment from the Geological Survey and made available three geologists, Jumchet Charaljavanaphet, Phong Phan Na Chiengmai, and Din Bunnag, and transportation; to His Excellency Field Marshal Phin Chunhavan, Minister of Agriculture, and Director-General Xujati Kambhu of the Royal Irrigation Department, who supplied an irrigation engineer, Adul Thavisri, and a car, a driver, and living quarters at many localities in the plateau were supplied; to His Excellency Lt. Gen. Prayoon Pamon Montri, Minister of Public Health, and Udom Kanishtharat, head of the Division of Sanitation, who made available a sanitary engineer, Chumphon Rakprathum, and supplied transportation at Surin, Sisaket, Buriram, Khorat, Khon Kaen, Udon Thani and Ubon, and reports of wells drilled by the Department of Health; to His Excellency Vice Admiral Luang Sunavin Vivadh, R. T. N., Minister of Interior, and Damrong Cholvijarana, Chief of Water Supply, who made available municipal maps and reports of wells drilled by the Municipal and Public Works Department; to His Excellency General Luang C. R. Seriroengrithi, General Manager of the State Railways of Thailand, and Luang Visol Vidhekal, Chief of Drilling, who made available logs of wells drilled at Khorat and Bua Yai.

Excellent cooperation was received also from Director E. O. Sessions of USOM, who, through his officers-Warrens, of Agriculture; Brand, of Health; Bisgood, of Industry; and Cale, of Education; and their staffs-made pertinent file data readily available, helped in arranging contacts, provided typing service, and in many other ways expedited the work.

\section{GEOGRAPHY}

By Adul Thavishi

\section{POLITICAL DIVISION}

Thailand has been a constitutional monarchy since 1932. The capital (Krung Thep) and principal administrative headquarters of the country are in Bangkok. 
Thailand has been divided into 70 changwats, or counties, each under the control of a commissioner (Kha Luang Pracham) who is appointed by and is directly responsible to the Minister of Interior (see fig. 1). Each changwat is subdivided into amphoes, or districts, each under the district officer (nai amphoe) who is assisted by one or more assistant district officers (palat amphoe) according to the extent of the district. If an amphoe is quite small, it is called king amphoe (subdistrict) or simply king, and has a palat amphoe as head.

The amphoe or king amphoe is subdivided into tambons, or villages, which are under an official called kamnan, and the tambon is made up of mubans, or hamlets, each headed by the senior of the village, called the phuyai ban. The duties of the phuyai ban are to report any case of crime to the kamnan and to furnish all possible facilities to the villagers as well as to strangers. Thus the phuyai ban and kamnan are influential men from whom geologists may seek assistance while doing fieldwork.

\section{MAPS}

The maps issued in the Thai language by the Royal Survey Department are of two scales, $1: 50,000$ and $1: 200,000$. The $1: 50,000$-scale map shows an area of about 135,000 square kilometers, including the central plain and part of the Khorat Plateau. There are 405 10-minute quadrangle sheets at $1: 50,000$, each showing about 333 square kilometers. The 1:200,000-scale maps are complete. On this scale there are 74 sheets, each covering a 1-degree quadrangle, or about 12,100 square kilometers.

A general map having a scale of $1: 2,500,000$ by Robert L. Pendleton, "Provisional map of the soils and surface rocks of the Kingdom of Thailand," was published by the Cadastral Survey Office, Bangkok, Thailand, in 1949; and another map, "Carte generale de l'Indochine Francaise," scale 1:2,000,000, was printed by the Army Map Service, U. S. Corps of Engineers, in 1954.

There are also the aeronautical charts of the United States Air Force, on a scale of $1: 1,000,000$, printed in English. Thailand is shown on charts of the following names and numbers: Irrawaddy River (556), Gulf of Tonkin (617), Gulf of Martaban (677), We Island (800), and Penang Island (859).

The Northeastern project map, with a scale of 1:500,000, prepared by the Royal Irrigation Department, includes the entire northeastern region and shows the irrigated areas and also the highways, both completed and under construction. Wells studied for this report were plotted on a modification of this map (see pl. 2). The city maps in plate 3 are modifications of the city maps of the Municipal and Public Works Department. 
TOPOGRAPHY AND DRAINAGE

The Khorat Plateau, comprising 155,000 square kilometers, is one of the main physiographic features of Thailand. It is named for the town of Khorat (Nakhon Ratchasima), the second largest settlement on the plateau. The plateau is a shallow basin or bowl-shaped area tilted slightly to the southeast. Its central part is a monotonous plain broken by gently rolling hills; its northern part consists of a crescentic strip of swampy lowland along the Mae Nam Khong. This river bounds the plateau on the north and east. The plateau is bounded on the west by the Thiu Khao Phetchabun and on the south by the outward-facing Phanom Dang Raek escarpment (see fig. 1, pl. 1).

The altitude of the western border of the plateau is about 200 meters above sea level. Along the Mae Nam Khong on the north and east the altitude is generally less than 150 meters. To the south the escarpment averages about 500 meters above mean sea level; however, altitudes extend up to 700 meters in places. Owing to the geologic structure of the area, the perimeter of the plateau to the west, south, and southeast is a steep outward-facing escarpment from which the land surface and the underlying rock formations slope gently inward to the center of the plateau. Resistant rock layers cropping out around the edge of the plateau form a cuesta-type topography (see pl. 5A). The surface of the plateau is essentially a gently rolling plain. Throughout the plateau there are scattered ridges, the most prominent along the western margin of the plateau and just south of Sakon Nakhon.

Large areas of the interior of the plateau are flooded during the wet season as a result of poor drainage; however, during the dry season, the lack of rainfall and high evaporation cause the area to be classed as semiarid during part of the year. The Mae Nam Mun and Nam Chi and their tributaries drain most of the plateau. They rise along the west rim, flow across the area, and enter the Mae Nam Khong near Ubon. The general slope of the Mae Nam Mun is very gentle across the central plateau; however, it steepens near Phibun, flows across rapids caused by dipping sandstone layers, and discharges into the Mae Nam Khong. The Nam Kam, which rises in Changwat Sakon Nakhon, flows northeast into the Mae Nam Khong, draining the northeast corner of the plateau. The Nam Kam is the outlet of the Nong Lahan depression, which contains the largest fresh-water lake in Thailand. The lake has an area of about 170 square kilometers during the rainy season but shrinks to a fraction of this size during the dry season. The Nam Songkhram constitutes a minor drainage system on the plateau (see pl. 2). 
It is evident from aerial photographs and topographic maps that the Mae Nam Khong has changed its course back and forth across much of the plateau. Many of these ancient meanders may be recognized from the air by their topographic expression and vegetation. In some meanders there are deposits of sand, clay, and gravel. These areas are heavily cultivated and characterized by rich soil, and in places by swamps. Elsewhere, the bedrock forms low ridges or cuestas, where the soil is less fertile, more sandy, and less conducive to rice cultivation. The ridge and sandy uplands are covered by large stands of scrubby woods.

In the southern part of the plateau, southeast of Buriram and southwest of Surin, the gently rolling surface is interrupted by elongated ridges formed by basaltic dikes and flows which lend variety to the countryside.

\section{CLIMATE}

The climate of the Khorat Plateau is characterized by precipitation that is light to moderate as compared with that in the northern, central, and southern parts of the country. Throughout Thailand, except in the peninsula, there is a rainy season during the southwest monsoon from May to early October, and a dry season from November to May, with abundant sunshine and a high rate of evaporation.

The plateau receives persistent rains during the southwestern monsoon from May to October. The average annual precipitation (determined by the Royal Naval Weather Department) is about $1,440 \mathrm{~mm}$ at Khorat, 1,300 $\mathrm{mm}$ at Khon Kaen, and $1,470 \mathrm{~mm}$ at Ubon. The average monthly precipitation is shown in figures 2 and 3 . Evaporation data are available for only two stations in the plateau; they show that evaporation exceeds precipitation during the period October through April at the weather stations at Udon Thani and Khorat. More than half the precipitation falls during the rice-growing season from June through September when noisture is needed most. From March until the middle of June temperatures generally range from $28^{\circ}$ to $32^{\circ} \mathrm{C}\left(82^{\circ}\right.$ to $\left.90^{\circ} \mathrm{F}\right)$.

The heat of the day, during this period, is relieved somewhat by wind movement, and the nights are fairly cool. Following the rainy season and until late February, the temperatures generally range from $18^{\circ}$ to $26^{\circ} \mathrm{C}\left(64^{\circ}\right.$ to $\left.79^{\circ} \mathrm{F}\right)$.

The area has an annual rainfall adequate to support much additional agricultural, industrial, and nunicipal development. Unfortunately, rainfall occurs during only part of the year, the rest of the year being rather dry. Adequate knowledge of annual streamflow, precipitation, temperature, and evaporation rates are needed to aid in control, storage, and development of surface-water supplies. 

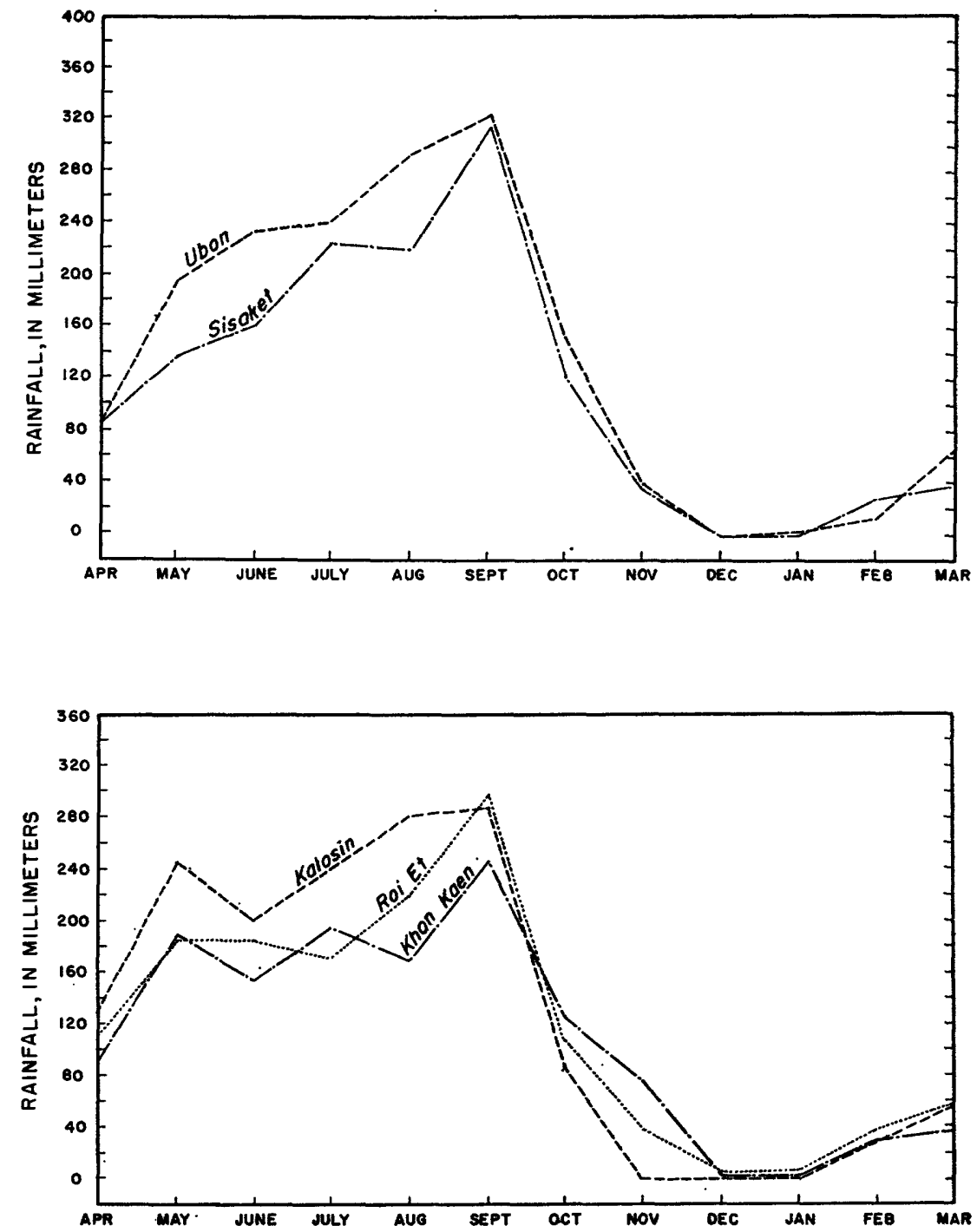

Floure 2.-Graphs showing average monthly rainiall at Ubon, Sisaket, Roi Et, Khon Kaen, and Kalasin.

Ground water in northeastern Thailand is derived almost wholly from rains that fall during the wet season, May to October. Some flooding occurs, and drainage of large tracts of flat land during this period becomes a problem. There are no detailed records of streamflow in northeastern Thailand; however, the Royal Irrigation Department in 1953 established stream gages at main stations along the principal streams of the region. These data will be of value to future water-supply projects. 


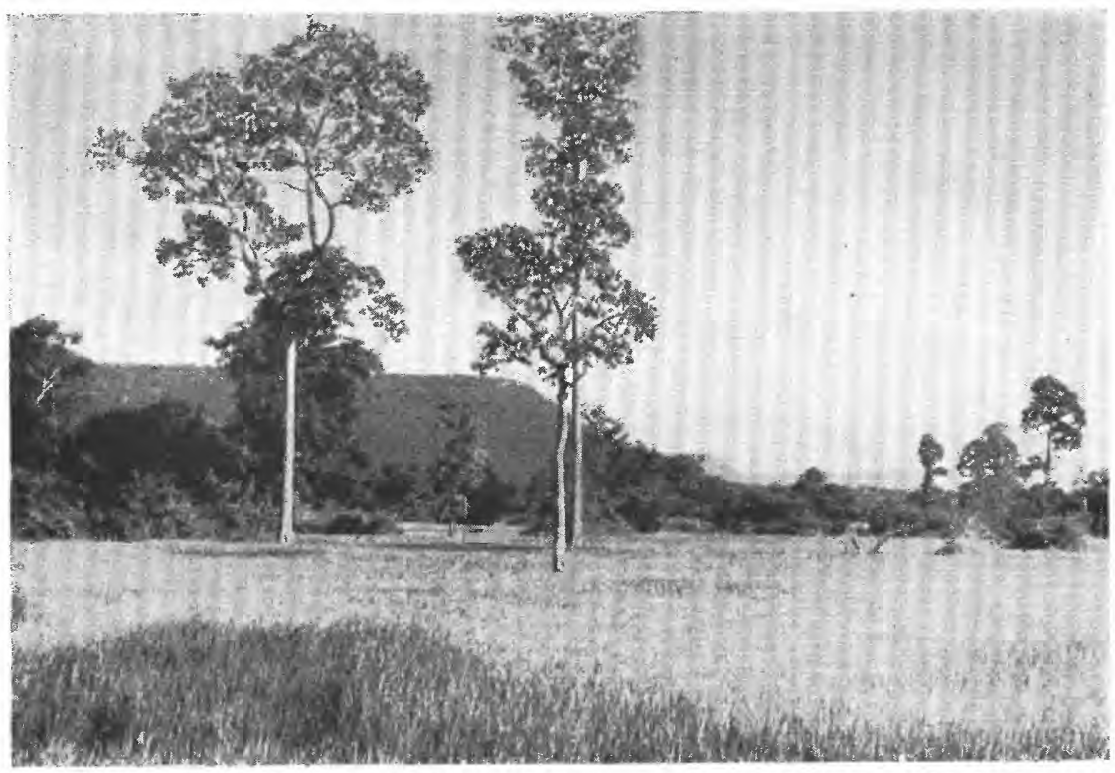

A. KHORAT ESCARPMENT FROM KILOMETER 45 ON PAKTHONGCHAI-KABINBERI ROAD.

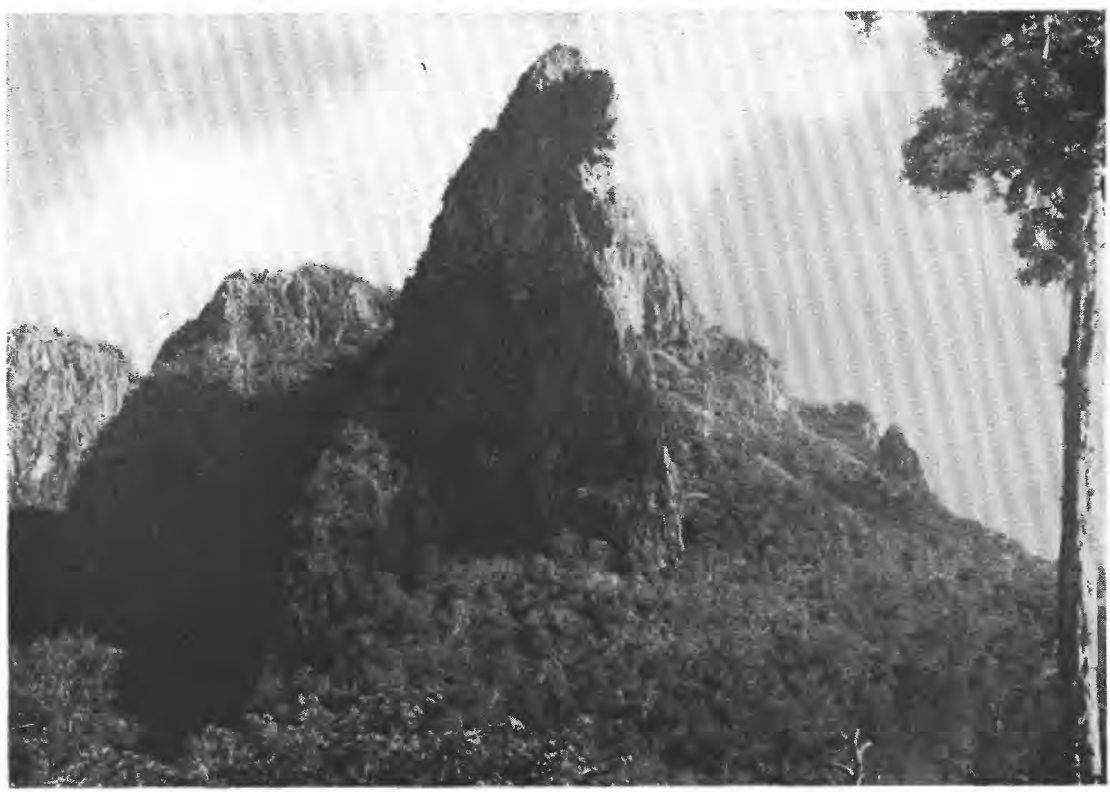

B. RAT BURI LIMESTONE EXPOSED AT PHA NOK KHAO ON KHON KAEN-LOEI ROAD. 


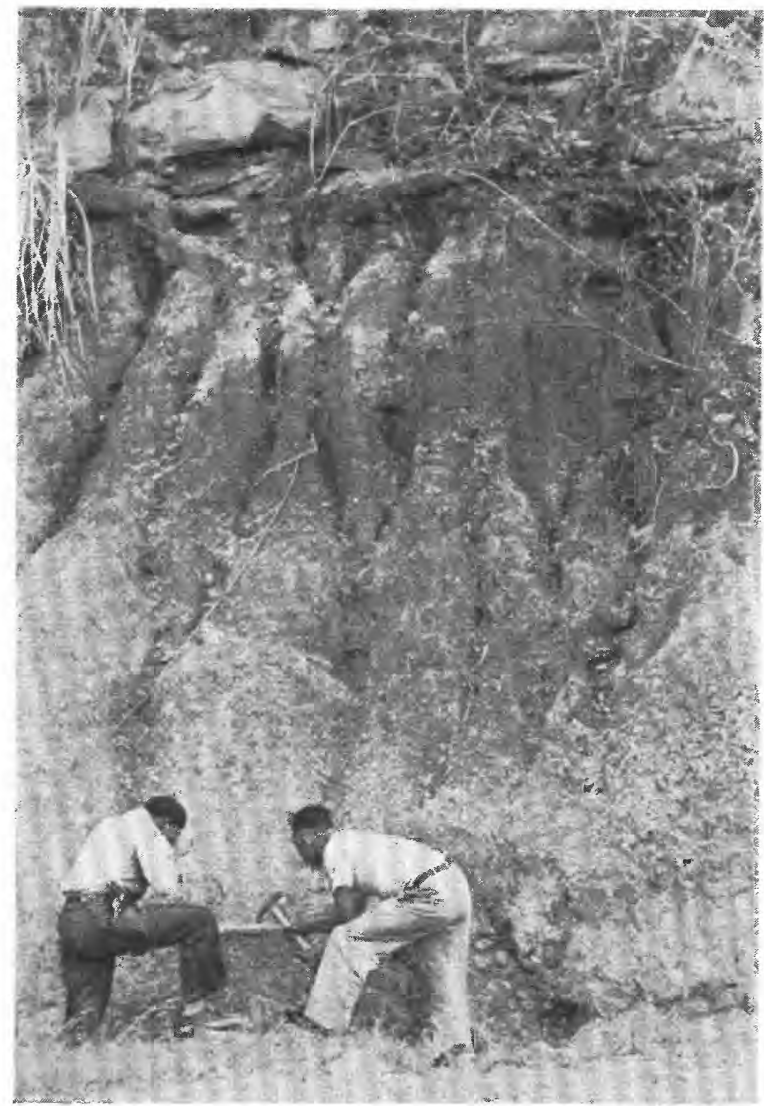

PHU KADUNG MEMBER OF KHORAT SERIES EXPOSED ON NONG BUA LAMPHU ROAD WEST OF UDON THANI. 

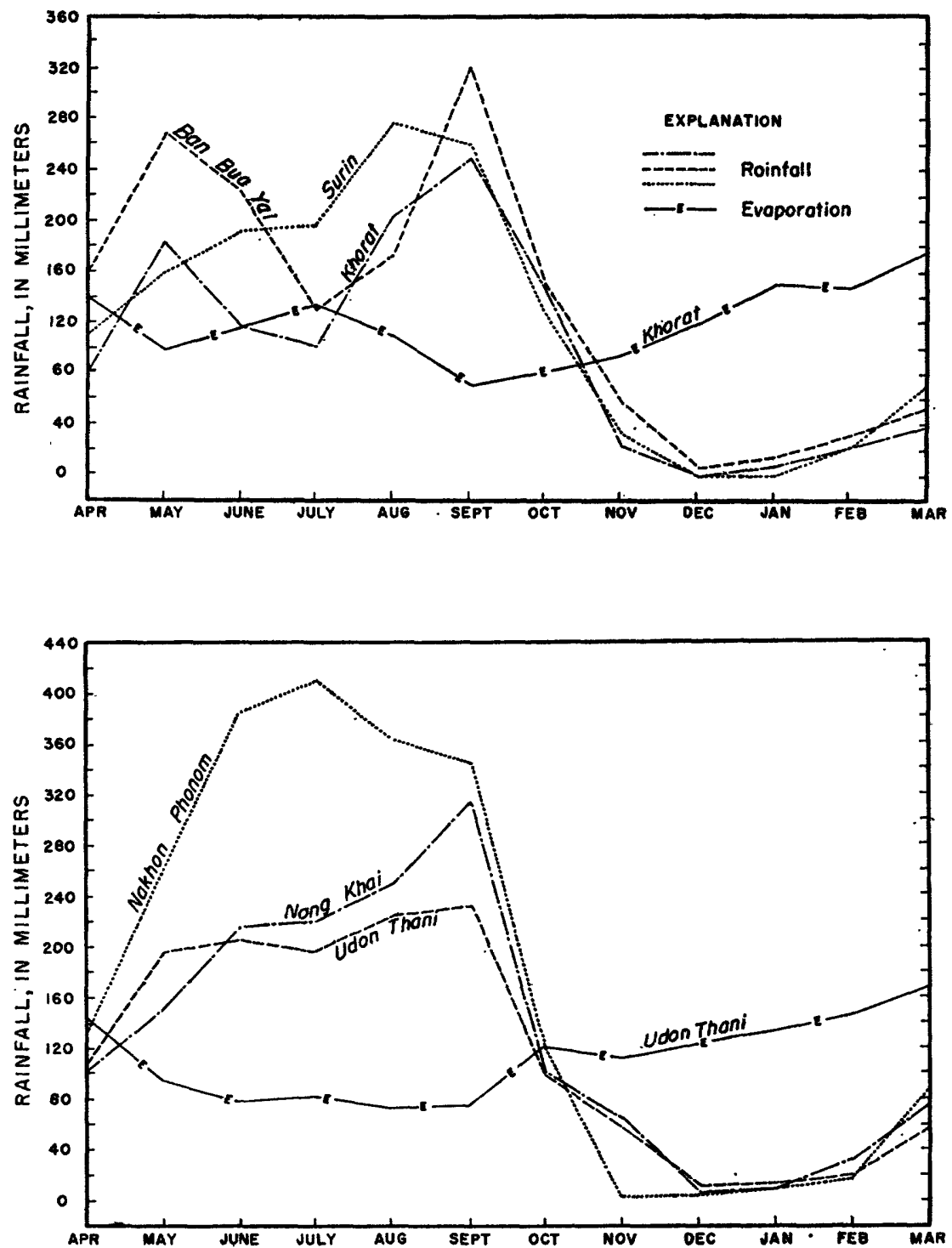

FiguRF; 3.- Graphs showing average monthly rainfall at Bua Yai, Surin, Khorat, Nakhon Phanom, Nong Khai, and Udon Thani and average monthly evaporation at Khorat and Udon Thani. Evaporation data from Royal Meteorological Department, Thai Navy (1938-48). Rainfall data from Royal Irrigation Department, Ministry of Agriculture (1906-1952).

\section{POPULATION}

According to the 1947 census by the Ministry of Interior, the population of the Khorat Plateau was about 6,210,000. The average population density was 37 per square kilometer, as compared with 66 
in central Thailand. The largest towns are Ubon, Khorat, and Khon Kaen.

The area includes 14 changwats, the largest of which is Ubon with a population of 862,200 . The other changwats and their populations are: Khorat, 737,200; Khon Kaen, 603,400; Udon Thani, 395,800; Sakon Nakhon, 280,300; Roi Et, 547,200; Mahasarakham, 396,900; Surin, 446,400; Sisaket, 461,300; Chaiyaphum, 291,598; Buriram, 350,500 ; Nong Khai, 144,500; Nakhon Phanom, 313,800; and Kalasin, 315,000 (see fig. 1).

There are 97 amphoes, 915 tambons, and 13,161 mubans in the area.

TRANSPORTATION

The Khorat Plateau is served by the State Railway of Thailand. Khorat is connected with Bangkok and is the junction from which an eastbound route connects Khorat with Ubon, through Buriram, Surin, and Sisaket, and a northbound route connects Khorat with Udon Thani, through Bua Yai, Phon, Ban Phai, and Khon Kaen.

Besides the railroad, there are roads joining almost all cities. The roads are not paved, except for a few kilometers within the limits of each city, but are kept passable most of the year by the Royal Highway Department. The principal villages of the Khorat Plateau are accessible throughout most of the year; however, during the rainy season road travel is very difficult. Occasionally even the Lop BuriKhorat, or access road to the plateau, is impassable because of washouts.

\section{GEOLOGY}

By Nitipat Jalichan, Din Bunnag, and P. E. LaMoreaux

\section{GEOLOGIC HISTORY}

Prior to Triassic time northeastern Thailand was part of a great land mass of folded rocks of Permian age and older. Erosion of this land mass reduced the area to a peneplain. In Triassic time, the area of the Khorat Plateau gradually subsided and possibly became in part a broad, nearly flat alluvial plain and in part a large, shallow sea in which a thick series of sediments accumulated (see table 1). The marine sedimentary rocks are predominantly red shale, but there are also beds of gray and tan medium-bedded to massive-bedded shale, fine sandy shale, and fine-grained sandstone. The reddish color of these rocks could be due to their origin in an area of reddish lateritic soils, or to oxidation of iron minerals deposited in the sediments. 
Climatic and depositional conditions must have been modified slightly in Middle Triassic time, and the older Triassic red beds were buried by tan, gray, green, and brown sandstone, sandy shale, and shale. These beds appear to grade upward progressively to lighter colors of tan and gray and from fine-grained to predominantly medium grained sandstone.

Depositional conditions gradually became more vigorous, and alluvial plains and shallow seas existed during deposition of beds of Late Triassic age in the area, for a series of medium- to coarse-grained tan, gray, and white arkosic crossbedded sandstone strata interbedded with some fine- and medium-grained sandstone and shale were deposited on the predominantly gray, tan, and green sandstone and shale.

Near the end of the Triassic period there was a change from a humid to a dry climate, with much wind action. Deposits of Jurassic age rest with apparent unconformity on deposits of Triassic age and consist predominantly of fine-grained sand and sandy shale and some thin beds of gypsum and salt. Crustal movement at the end of the Triassic period created the Phu Phan range of hills and two flanking shallow depressions, the Khorat and Sakon Nakhon basins. Water accumulated in these depressions and over thousands of years became increasingly salty. Increase in salinity as a result of confinement and periodical addition of water through sinking of the basin floor gave rise to salt and gypsum beds. These deposits were covered by clay and sand during a subsequent encroachment by the sea, or by alluvial deposits laid down over a broad plain near the sea.

Near the end of Jurassic time, the land was uplifted in three stages. Evidence of this is the three peneplained surfaces: The first plain forms the crest of the present Phu Kadung and Phu Phan ranges, and probably was formed in Cretaceous time; the second plain has a general surface elevation of about 180 meters and probably was formed in Miocene and Pliocene time; the third plain has a general surface elevation of about 140 meters and probably was formed in Pleistocene time. According to Wallace Lee (1927), there was yet another uplift of 75 meters, as evidenced by the drop in level of the Nam Mun at its entry into the Mae Nam Khong.

The late uplifts may have created faults in the rocks of Triassic and Jurassic age, through which basalt dikes and flows entered in the Surin, Buriram, and Sisaket areas. The vulcanism is believed to have been the last important geologic event in the northeastern region prior to the present cycle of erosion. 
14 GEOLOGY AND GROUND WATER, KHORAT PLATEAU, THAILAND

\begin{tabular}{|c|c|c|c|c|c|c|}
\hline 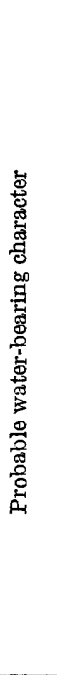 & 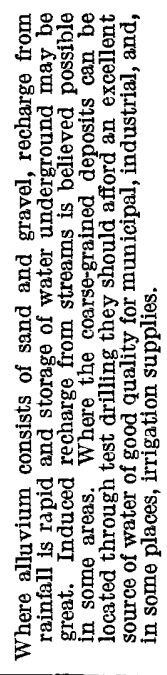 & 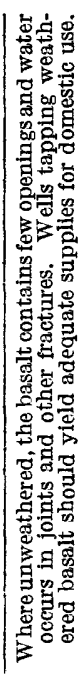 & 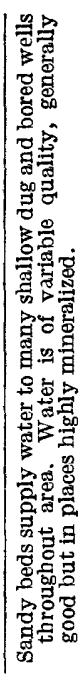 & 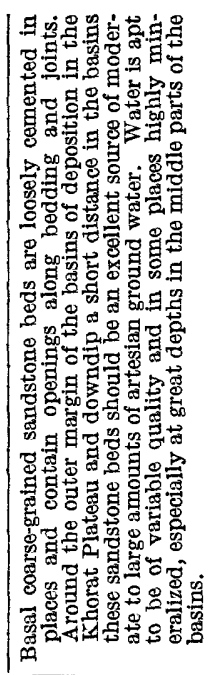 & 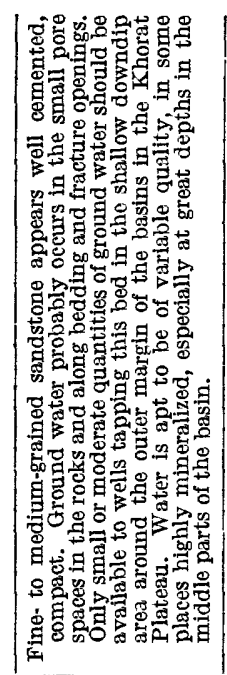 & 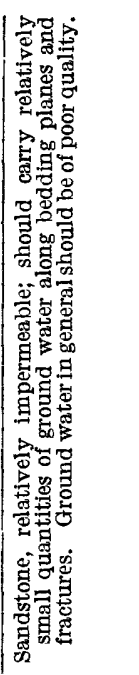 \\
\hline 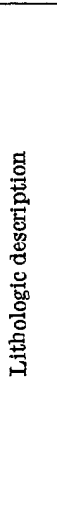 & 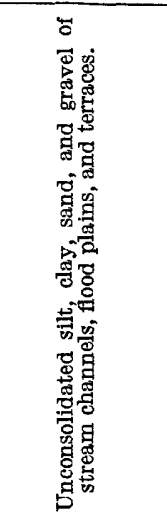 & 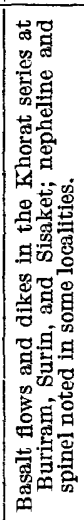 & 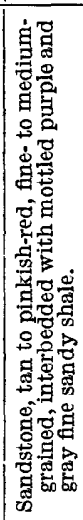 & 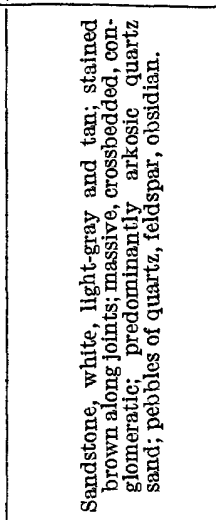 & 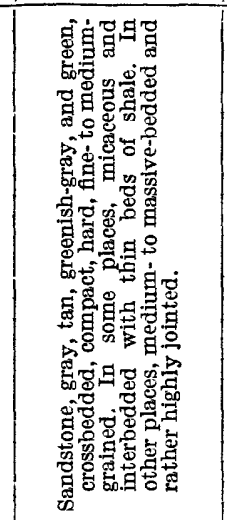 & 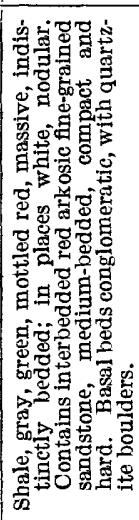 \\
\hline 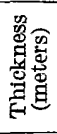 & 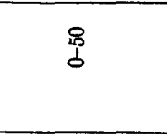 & $\widehat{\Theta}$ & 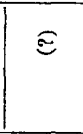 & ి్లి & $\begin{array}{l}8 \\
0 \\
0 \\
0 \\
0\end{array}$ & $\begin{array}{l}\mathscr{8} \\
\frac{\mathbb{T}}{4} \\
\stackrel{8}{4}\end{array}$ \\
\hline $\begin{array}{l}\text { 苜 } \\
\text { 莬 } \\
\end{array}$ & 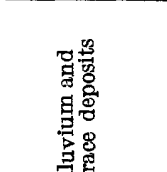 & 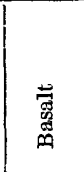 & 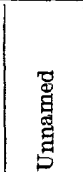 & 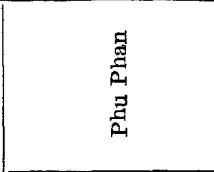 & 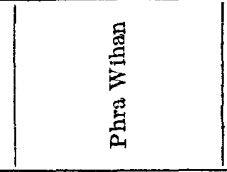 & 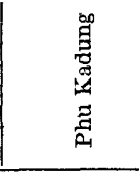 \\
\hline & & & & \multicolumn{3}{|c|}{ 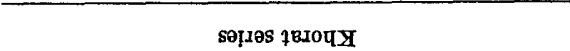 } \\
\hline 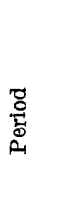 & 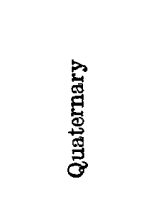 & 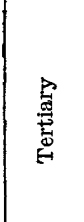 & 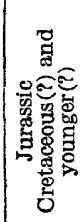 & \multicolumn{3}{|c|}{ 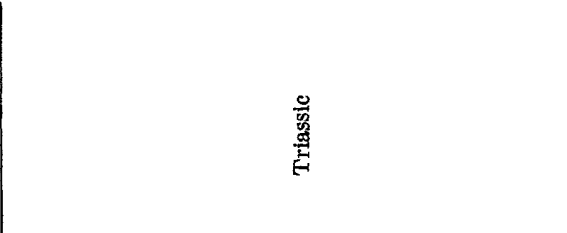 } \\
\hline
\end{tabular}




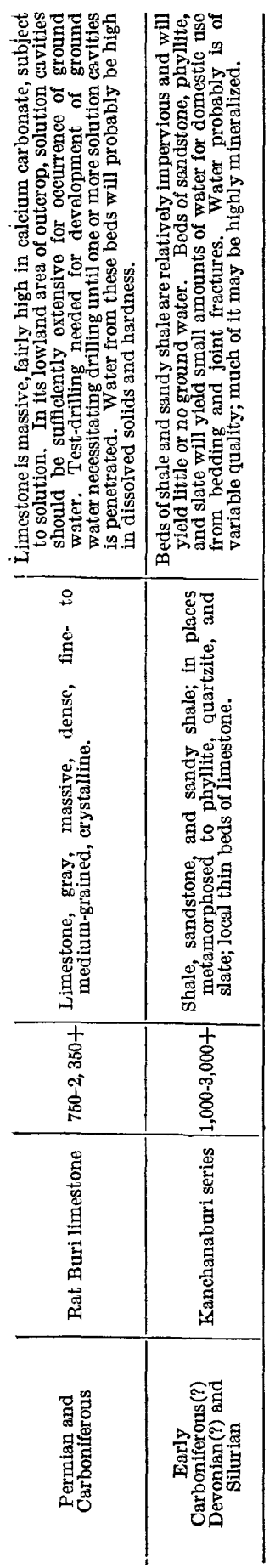




\section{GENERAL STRUCTURE}

Lee (1923, p. 40) reports that the Khorat Plateau occupies a unique position structurally at the center of a great series of concentric mountain folds that sweep southward from the end of the Himalaya. Mountains through Burma and the Malaya peninsula and curve eastward through Indonesia and northward to the Philippines.

In this report the Khorat Plateau is divided into three structural features: (1) the Khorat basin, (2) the Sakon Nakhon basin, and (3) the Phu Phan range (see fig. 4).

\section{KHORAT AND SAKON NAKHON BASINS}

About the end of Triassic time, the Phu Phan hills were formed as a series of gentle folds in rocks of Triassic age. Depressions formed on each side of the range and erosion removed sediments from the uplands and deposited them into slowly subsiding basins. The Khorat basin includes Changwats Khorat (Nakhon Ratchasima), Chaiyaphum, Buriram, Surin, Sisaket, Ubon, Roi Et, Mahasarakham, and Kalasin; the Sakon Nakhon basin includes Changwats Sakon Nakhon, Nong Khai, Udon Thani, Khon Kaen, and Nakhon Phanom (see pl. 2).

\section{PHU PHAN RANGE}

The Phu Phan range consists of at least three parallel folds striking roughly to the northwest (Lee, 1923). The folds begin near Phibun east of Changwat Ubon and extend through the northern part of Changwat Kalasin and the southern parts of Changwats Sakon Nakhon and Nakhon Phanom. The Phu Phan range extends at least as far northwest as Amphoe Waritchaphum in Changwat Sakon Nakhon. The structure is about 45 kilometers wide and evidence of its extent may be seen in rock exposures along the roads between Sahatkhan and Sakon Nakhon and between Roengnoktha and That Phanom (see pl. 4).

\section{ROCK UNITS}

SEQUENCE AND GENERAL FEATURES

In the Khorat Plateau there is a rather monotonous thick series of predominantly red, tan, gray, and brown fine-grained sandstone and shale beds, a major part of which have been assigned to the Triassic system. These beds are underlain by folded rocks of Paleozoic age: the shale and sandstone of the Kanchanaburi series and in some areas by the gray crystalline Rat Buri limestone. They are overlain by other beds of Triassic age.

Basalt, probably of Tertiary age, crops out in the southern part of the plateau near Surin, Sisaket, and Buriram. It occurs in small, isolated areas as dikes and flows. 


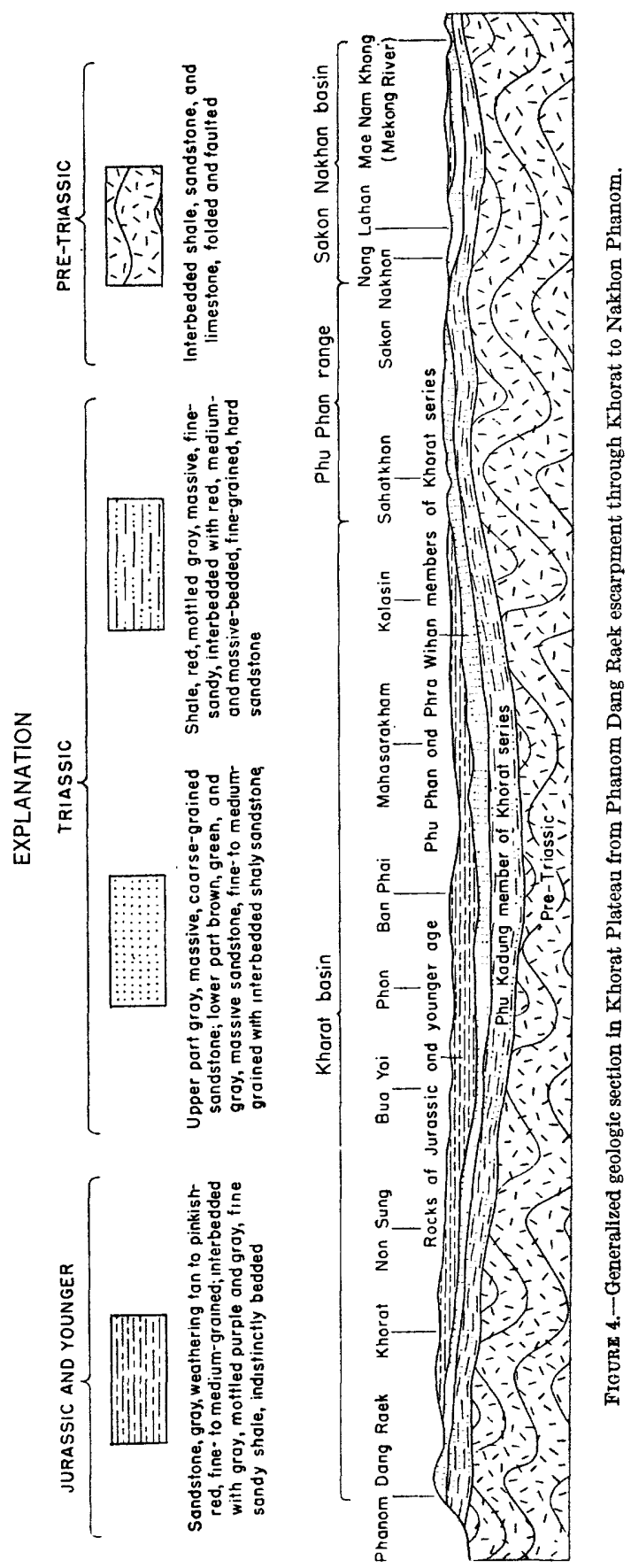


Deposits of Quaternary age consist of alluvial silt, clay, sand, and gravel in the flood plains, stream channels, and terraces. These beds, though present throughout the area, are not delineated in plate 4 and in figure 4 of this report.

\section{KANCHANABURI SERTES (SILURIAN?, DEVONIAN?, AND EARLY CARBONIFEROUS)}

Rocks of the Kanchanaburi series crop out along the base of the Khorat escarpment. These rocks are shale, sandstone, and sandy shale that in places contain a few beds of limestone. They have been complexly folded into steep folds trending roughly north-south. The force creating these folds did not cause extensive metamorphism throughout the series; however, in some areas the shale and sandstone have been converted to slate, quartzite, and phyllite.

The shale is massive, hard, and compact, and at some localities appears nodular. Where freshly exposed it is dark to light gray; where weathered it is commonly variegated or mottled red, light green, and gray. Sandstone and argillaceous sandstone are found interbedded with the shale in Changwat Loei. From west of Changwat Loei to Ban Phu Sawan along the Loei-Dan Sai highway, most of the exposed rocks are massive-bedded, indurated sandstone, with quartz grains in an argillaceous matrix and with pyrite as an accessory mineral. These rocks are also well exposed in the highway embankments between kilometers 148 and 153 on the Khon Kaen-Loei road.

\section{RAT BURI LIMESTONE (CARBONIFEROUS? AND PERMIAN)}

The Rat Buri limestone crops out along the northwestern side of the Khorat Plateau and consists of massive, crystalline, light-gray to gray limestone, in part dolomitic. The limestone for the most part has been folded and in some localities recrystallized to marble. In some areas Lee $(1923$, p. $3-4)$ reports beds of sandstone and shale interbedded with the limestone. Hogbom (1914, p. 1-16) records shale interbedded with the limestone along the west side of the Khorat Plateau.

The Rat Buri limestone lies unconformably on the Kanchanaburi series, and is overlain unconformably by sandstone of the Khorat series. The lower part of the Rat Buri limestone contains thin layers of chert nodules containing fossils of Permian age.

A good exposure of the Rat Buri limestone in the area of this study is at Pha Nok Khao, a limestone mountain bordering the highway from kilometer 105 to 126 on the road from Khon Kaen to Loei. Here the limestone crops out as a rugged, precipitous salient with nearly vertical walls (see pl. $5 B$ ). At Pha Nok Khao the limestone is massive, dark gray, dense, and crystalline. The limestone surfaces 
of the sides of the mountain have beautiful fluting from erosion by solution.

\section{KHORAT GERIES (TRIASSIC)}

Rocks of Triassic age are exposed in a large continuous circular pattern in most of the Khorat Plateau and in one isolated area along the Mae Nam Khong in the northeastern part of the area. Beds of Triassic age in the area are assigned to the Khorat series and consist of indurated shale, shaly sandstone, fine- to coarse-grained sandstone, and conglomerate. These beds in the Khorat Plateau are thought, by Lee $(1927$, p. 411$)$ to have a thickness of 1,200 meters.

The Khorat series is believed to have been formed in nearly flat alluvial plains or in relatively shallow seas under conditions not conducive to the preservation of fossils. One of the few localities where fossils are known to occur in the Khorat series is 8 kilometers south of Muang Chiang Rai near the northern border of Thailand. At this locality Wallace Lee made a collection in 1923, and forwarded the specimens to the U. S. Geological Survey. T. W. Stanton identified the specimens and assigned these beds to the Triassic system and probably to the Middle Triassic series (Brown, Buravas, Charaljavanaphet, Julichandra, Johnston, Sresthaputra and Taylor, 1951, p. 37). Petrified wood, lignite fragments, and carbonaceous shale were noted in some road-cut exposures studied for this report, and at Phu Kadung, near the base of the mountain, a sample of what appeared to be filled borings was collected from a sandy shale.

For this report the Kborat series has been divided into three members on the basis of lithology.

\section{PHU KADUNG MEMBER}

The Phu Kadung member is the oldest member of the Khorat series. It consists of a basal conglomerate of red shale containing boulders of quartzite from the Kanchanaburi series. The basal conglomerate is overlain by massive, fine- to coarse-grained, sandy, and micaceous purple shale, mottled gray and green. The shale is interbedded with compact fine-grained sandstone that is slabby in some places and of medium thickness to massive bedded in other places. This member lies unconformably on rocks of Paleozoic age. The Phu Kadung member is best exposed along the base of the Khorat escarpment at Phu Kadung, at Khao Phra Wihan, and at kilometer 276 on the Lop Buri-Khorat road. At these localities the member has a maximum thickness of 480 meters (see fig. 5).

The Phu Kadung member is exposed in fresh road cuts along the new highway from Udon Thani to Nong Bua Lamphu (see pl. 6), and 


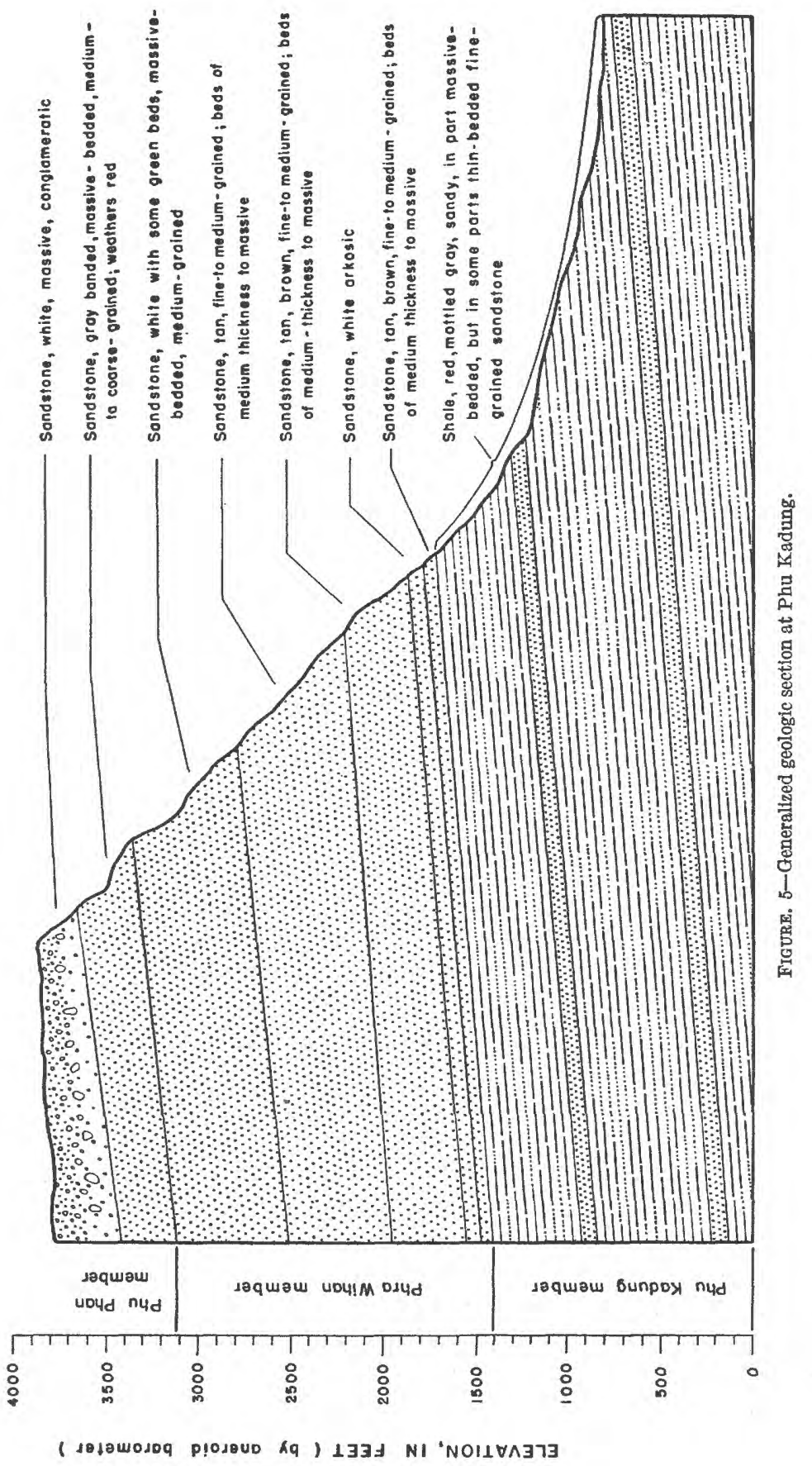


in exposures on the Khorat-Kabinburi road from kilometer 63 to 69.5 . Outcrops at these localities are described as follows:

Geologic sections on the Khorat-Kabinburi road

Kilometer 63:

Thickness (feet)

Sandstone, gray; weathers to tan, massive-bedded hard fine-grained quartz sand; slightly micaceous, quartzitic

$40+$

Sandstone, shaly, gray, weathers to fine- to medium-grained slightly micaceous quartz sand; weathers pinkish red along hexagonal blocks

Kilometer 65:

Shale, red, tough, fine-grained, sandy, mottled greenish-gray; weathers hackly to angular blocky and contains lime nodules along joint cracks

Kilometer 69.5:

Sandstone, gray; flaggy to medium thick bedded, very micaceous with reddish banding.

PHRA WIHAN MEMBER

The Phra Wihan member lies conformably on the Phu Kadung member and consists of sandstone, green, gray, tan, and white sandstone, predominantly of fine- to medium-grained quartz sand that is moderately well sorted and contains many scattered flakes of mica and some banding. Ripple marks, thin layers of lignite and petrified wood, and lime nodules occur in the upper 20 feet. The sandstone beds are predominantly of medium thickness, but there are some thin beds interbedded with a few tough shale and sandy shale beds.

The Phra Wihan member is well exposed along the eastern and southern escarpment of the Khorat Plateau. Excellent exposures may be seen in road cuts up the face of the escarpment from kilometer 289 to 295 on the Lop Buri-Khorat highway, near the top of Phu Kadung, at kilometer 40 on the new highway from Udon Thani to Loei (see pl. $7 A$ ), at Phra Wihan, and on the road south from Khorat to Kabinburi. This member is about 400 meters thick at Phra Wihan where it is exposed in an overhanging cliff (see fig. 6). Characteristic sections of the Phra Wihan member crop out along the Lop Buri-Khorat road and are described as follows:

Geologic sections of Phra Wihan member

Thickness $($ feet)

Kilometer 281.8: Sandstone, light-tan; weathers to massive, hard, finegrained, quartz sand, brown on surface; arkosic with scattered fine muscovite flakes and angular dark mineral grains. Some thin-bedded lightgray fine-grained sandstone beds near the base. Beds strike N. $20^{\circ} \mathrm{W}$., $\operatorname{dip} 52^{\circ} \mathrm{E}$

Kilometer 282: Sandstone, tan; weathers gray-brown; massive beds with pronounced crossbedding. Lime nodules weathered out and scattered along the top of the massive beds near top of Phra Wihan member...-

Kilometer 286: Sandstone, massive-bedded, hard, gray; weathers brown to red-brown; beds consist of predominantly coarse-grained and subangular quartz sand, in places conglomeratic and containing rounded indurated red shale pebbles as much as 2 inches in diameter. 


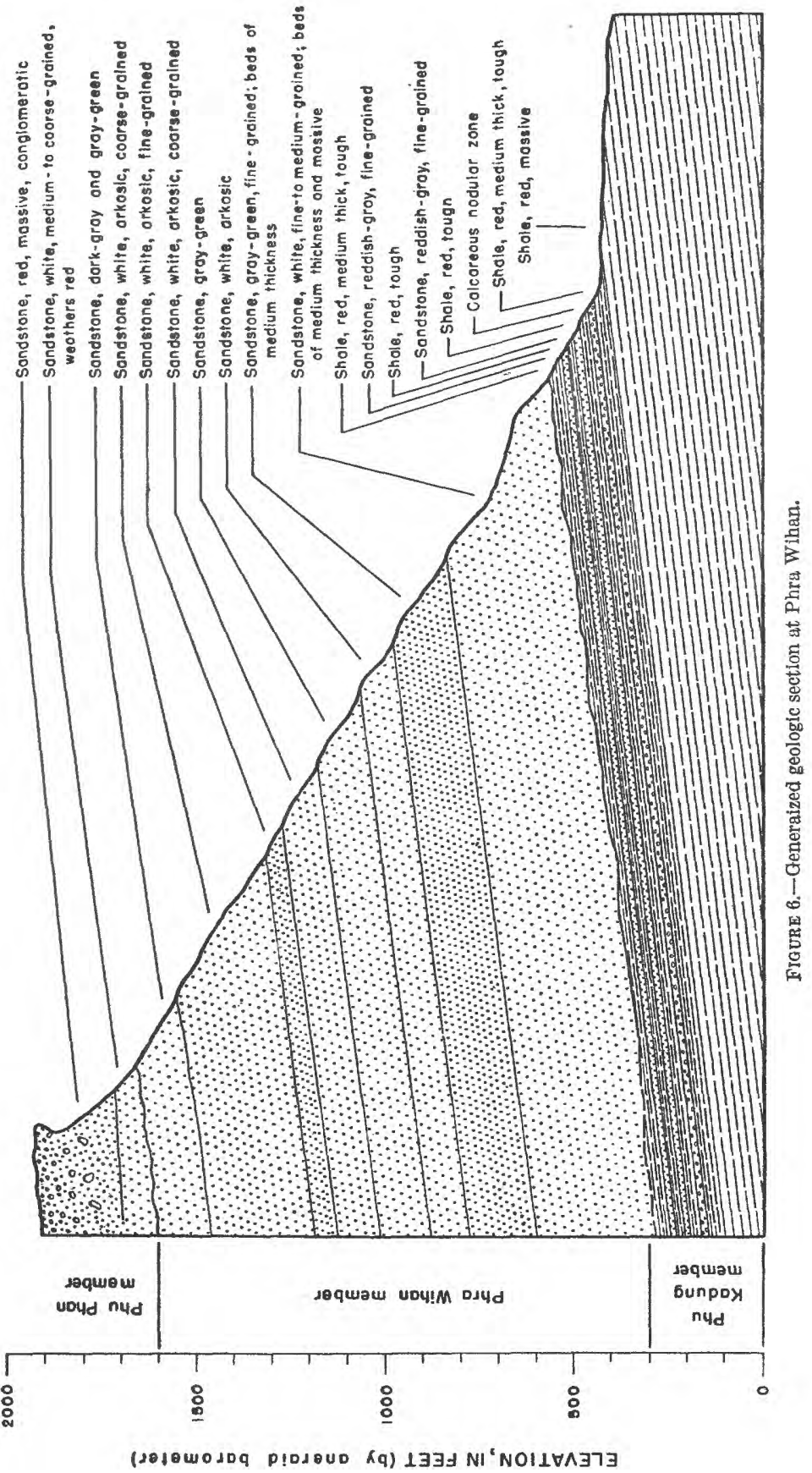




\section{PHO PHAN MKMBER}

The Phu Phan member consists of fine- to coarse-grained arkosic sandstone and conglomerate. The sandstone is subangular to subrounded quartz sand. It crops out and forms hills near the top of and around the margin of the escarpment of the Khorat Plateau. The member is predominantly coarse-grained or pebbly sandstone near its base and includes lenses of conglomerate with quartz, feldspar, and obsidian pebbles. It grades upward into medium- and finegrained sandstone that is crossbedded and at some localities is ripple marked. The beds are gray and tan, weathering light gray and white, and brown iron staining is common along jointing. The Phu Phan member is characteristically massively bedded; however, it contains some beds of medium thickness.

A chart showing comparative exposed thickness of the members of the Khorat series is as follows:

\begin{tabular}{|c|c|c|c|}
\hline \multirow{2}{*}{ Location of section } & \multicolumn{3}{|c|}{ Thickness (feet) 1} \\
\hline & $\begin{array}{c}\text { Phu Kadung } \\
\text { member }\end{array}$ & $\begin{array}{c}\text { Phra Wihan } \\
\text { member }\end{array}$ & $\underset{\text { member }}{\text { Phu Phan }}$ \\
\hline $\begin{array}{l}\text { Phu Kadung } \\
\text { Phra Wihan }\end{array}$ & $\begin{array}{l}21,400 \\
2300+\end{array}$ & $\begin{array}{l}1,700 \\
1,300\end{array}$ & $\begin{array}{l}650 \\
300\end{array}$ \\
\hline
\end{tabular}

1 Measured by aneroid barometer.

2 Partially covered.

Excellent exposures of the Phu Phan member may be seen at kilometer 296 on the Lop Buri-Khorat highway, in the exposures near the top of Phu Kadung mountain, at Phra Wihan, and at kilometers 42 and 55 south of Khorat on the Khorat-Kabinburi road (see pl. $7 B$ ). Two of these localities are described as follows:

Geologic section in road cut at kilometer 296 on Lop Buri-Khorat road

Khorat series:

Phu Phan member: Sandstone, grayish-tan; weathers to white, massive-bedded, crossbedded; predominantly croarse-grained quartz sand with much granular and pebbly quartz. Sand and pebbles are rounded to subrounded and composed predominantly of clear

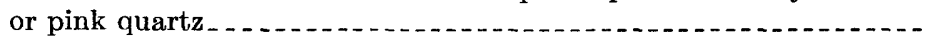

Phra Wihan member: Sandstone, tan to brown, massive, fine- to medium-grained, micaceous 
Geologic section at kilometer 36 on the road from That Phanom to Ubon

Khorat series:

Thickness (feet)

Phu Phan member:

Sandstone, light-gray, massive-bedded, crossbedded, coarsegrained to conglomeratic .................... 9

Sandstone, white, arkosic, coarse-grained . . . $\ldots \ldots \ldots \ldots \ldots$

Sandstone, tan to gray, massive-bedded, medium- to coarsegrained, pebbly

Phra Wihan member:

Sandstone, white and light-gray, massive-bedded, dense, finegrained; contains scattered lime nodules

Sandstone, tan, fine- to medium-grained; contains lime nodules; interbedded with red shaly sandstone

Sandstone, gray and red, banded, massive-bedded, fine- to medium-grained. Beds dip $10^{\circ} \mathrm{NW}$. and strike S. $50^{\circ} \mathrm{W} \ldots \ldots$.

\section{BEDS OF JURASSIC AND CRETACEOUS (?) AGE}

Sandstone, sandy shale, and mottled shale, the lower part probably of Jurassic age and the upper part an undetermined age, rest on beds of the Khorat series. Some of these sediments in the central part of the basin may be Cretaceous or younger.

From the edge of the Khorat escarpment on the Lop Buri-Khorat road eastward, beds of sandstone and shale are exposed from oldest. to youngest. At kilometer 296 the contact between the Phra Wihan and Phu Phan members is exposed; from this point toward the center of the basin the road crosses a series of westward-facing cuesta ridges that slope gently eastward. At the crest of nearly every ridge there are outcrops of fine- to medium-grained, medium-thick and massive-bedded gray sandstone that weathers to pinkish red. These ridges are at kilometers 298.6, 299, 300, 301, 302, 303, 304, 305, 306.5, $308,309,310,310.5$, and 312.5. The sandstone beds cropping out at the top of the ridge at kilometer 312.5 contain many nodules of calcium carbonate that have weathered out and are scattered along the land surface. From this ridge the road slopes down the dip of these beds to a low-relatively flat area underlain by dark soil at kilometer 317. Topography and soil characteristics in this lowland indicate a lithologic break that may be of stratigraphic significance in separating beds of Triassic and Jurassic age. From kilometer 332 to 333 the road crosses an escarpment where there is an exposure of fine-grained, reddish-pink sandstone at the top. This bed is well exposed in a series of shallow road cuts to the east where the road crosses a series of cuestas.

The contact between beds in the Khorat series and rocks of Jurassic age is not clearly defined in this area. Probably some of the sandstone beds exposed in the gently eastward sloping ridges east of the 
contact between the Phra Wihan and Phu Phan members of the Khorat series at kilometer 296 are of Jurassic age. Time was too limited during this reconnaissance to describe the outcrops in detail and determine their significance. A knowledge of the composition and structure of the beds in this area is needed.

In the central part of the Khorat basin there are few good exposures of bedrock, and to date only limited subsurface geologic information is available. There have been no deep test wells drilled in the Sakon Nakhon basin in the northern part of the plateau, and only four deep test wells were drilled in the Khorat basin. From these wells an indication of the type of sediments underlying the flat upland surface can be obtained. Composite logs were compiled from a partial set of samples and drillers' logs. Available geologic data on these wells are summarized as follows:

\section{Driller's log for test hole at railroad station at Khorat}

\begin{tabular}{|c|c|c|}
\hline & $\begin{array}{l}\text { Thickness } \\
\text { (feet) }\end{array}$ & $\begin{array}{l}\text { Depth } \\
(\text { feet })\end{array}$ \\
\hline lay _. & 2. 6 & 2.6 \\
\hline Clay, sandy, with concretions _. & 7.9 & 10. 5 \\
\hline Clay, yellow, with coarse sand & 22. 3 & 32. 8 \\
\hline Clay, yellow, with fine sand & 24. 0 & 56. 8 \\
\hline Clay, lateritic, with fine gravel. & 8. 6 & 65. 4 \\
\hline Clay, lateritic, with coarse sand_. & 14. 3 & 79. 7 \\
\hline Clay, red, indurated with small pebbles & 10. 5 & 90. 2 \\
\hline Clay, red, indurated with coarse pebbles & 12. 6 & 102. 8 \\
\hline Clay, red, indurated with few small pebbles & 9.1 & 111. 9 \\
\hline Clay, red, soft & 21. 7 & 133. 6 \\
\hline Clay, light-blue, soft & 13. 7 & 147. 3 \\
\hline Clay, light-blue, with rock fragments... & 73. 2 & 220. 5 \\
\hline Clay, greenish-gray & 27. 5 & 248. 0 \\
\hline Clay, greenish-gray, with weathered rock fragments & 10. 0 & 258. 0 \\
\hline Clay and laterite with some gravel & 48. 1 & 406. 1 \\
\hline th laterite and salt & 25. 3 & 431. 4 \\
\hline Salt, with hard clay & 38. 6 & 470. 1 \\
\hline Salt, with hard clay and dark-brown sandstone & 13. 9 & 483. 9 \\
\hline Clay, red, with dark-brown sandstone & 16. 7 & 500.6 \\
\hline
\end{tabular}

Driller's log for test hole at railroad station at Bua Yai

Sandy soil, yellow

Thickness (feet)

Depth 4. 8

Clay, lateritic, and white sand

1. 9

6. 7

Shale, red, sandy, with fine sandstone $\ldots \ldots \ldots . .203 .6$

210. 3

No report

85. 0

295. 3

Shale, red.

442. 9

738. 2

Clay 
Driller's log for test hole in military compound at Khorat

Sandy soil

Thickness (feet)

Laterite.

9. 8

Depth
(feet)

Clay, white

8. 6

14. 7

Clay, yellowish-white.

3. 3

Clay, plastic.

9. 5

Clay, sandy

6. 6

Clay, sandy, plastic

7. 9

Sand

30. 6

Sand, fine; no water

3. 3

Sand, fine, loose; (brackish water rose in test well to $16.4 \mathrm{ft}$ below land surface)

Laterite .

4. 198.4

6. $6 \quad 105.0$

Clay, gray

3. 3

108. 3

Clay, lateritic

Clay, lateritic, with pebbles

22. 9 131. 2

62. $4 \quad 193.6$

Clay, lateritic, with rock fragments

60. $7 \quad 254.3$

Clay, red, plastic (salt water rose in well to $13.1 \mathrm{ft}$ below land surface)

14. 1268.4

Clay, gray

59. 7 328. 1

Clay, gray, odor like petroleum gas

Clay, red (salt water rose in well to $4.9 \mathrm{ft}$ below land surface) ...

28. 8356.9

24. $7 \quad 381.6$

Driller's log for test hole in military compound at Khorat

\begin{tabular}{|c|c|c|}
\hline & $\begin{array}{c}\text { Thickness } \\
\text { (feet) }\end{array}$ & $\begin{array}{l}\text { Depth } \\
\text { (feet) }\end{array}$ \\
\hline Soil, red, sandy_ & 9. 8 & 9.8 \\
\hline Sand, red, with pebbles & 6. 9 & 16. 7 \\
\hline Sand & 19.7 & 36. 4 \\
\hline Clay, plastic & 14. 8 & 51. 2 \\
\hline Sand & 4. 9 & 56. 1 \\
\hline Clay, plastic & 4. 9 & 61.0 \\
\hline ellow ....... & 5. 9 & 66. 9 \\
\hline Clay, plastic & 2. 3 & 69. 2 \\
\hline Sand, yellow, with gravel & 8. 6 & 77. 8 \\
\hline plastic & 21. 5 & 99. 3 \\
\hline d gravel & 12. 9 & 112. 2 \\
\hline 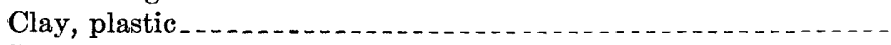 & 24. 6 & 136. 8 \\
\hline 品 & 14. 8 & 151. 6 \\
\hline - & 12. 7 & 164. 3 \\
\hline ( & 116. 2 & 280.5 \\
\hline Clay, white & 9.9 & 290.4 \\
\hline Rock & 8.8 & 299. 2 \\
\hline plastic, with rock fragments & 89. 7 & 388. 9 \\
\hline n & & 388.9 \\
\hline
\end{tabular}

\section{TERTIARY IGNEOUS ROCKS}

Basalt dikes and flows occur in isolated outcrops along the southern edge of the Khorat Plateau between the State Railway of Thailand and the Phanom Dang Raek escarpment. There are large flows southeast of Buriram, and southwest of Surin. The largest lava flow 


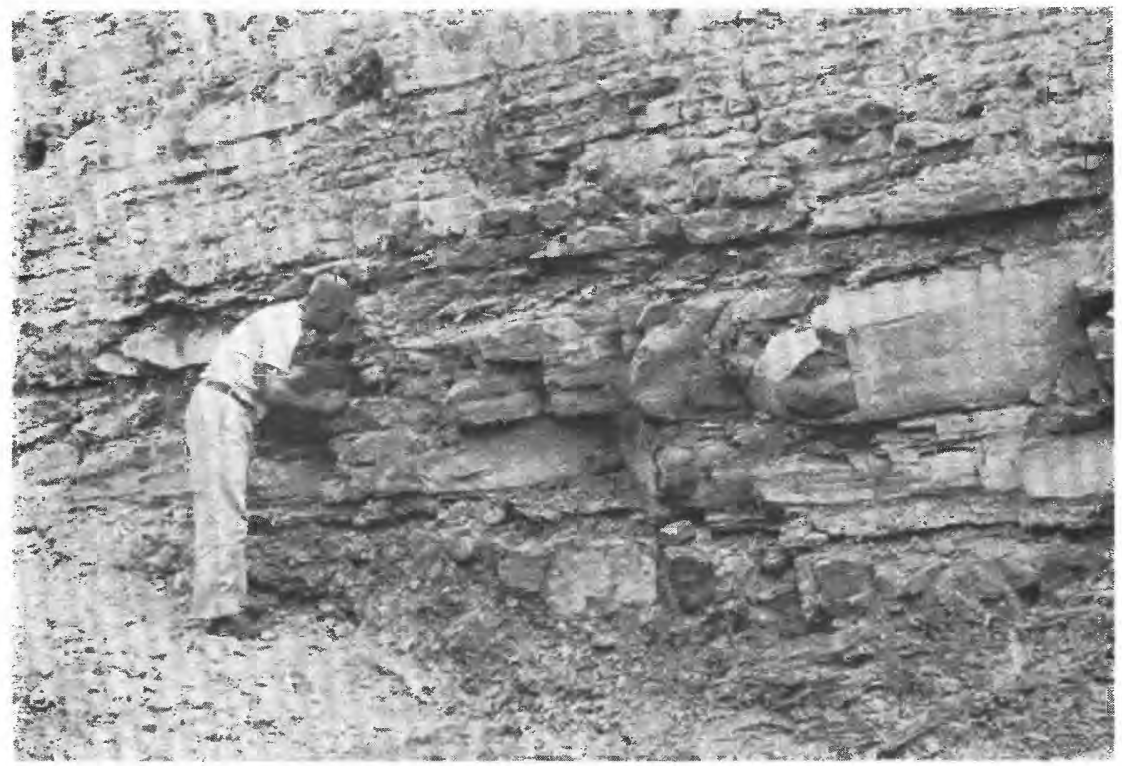

A. PHRA WIHAN MEMBER OF IHE KHORAT SERIES EXPOSED NEAR KILOMETER 40 ON THE UDON THANI-LOEI ROAD.

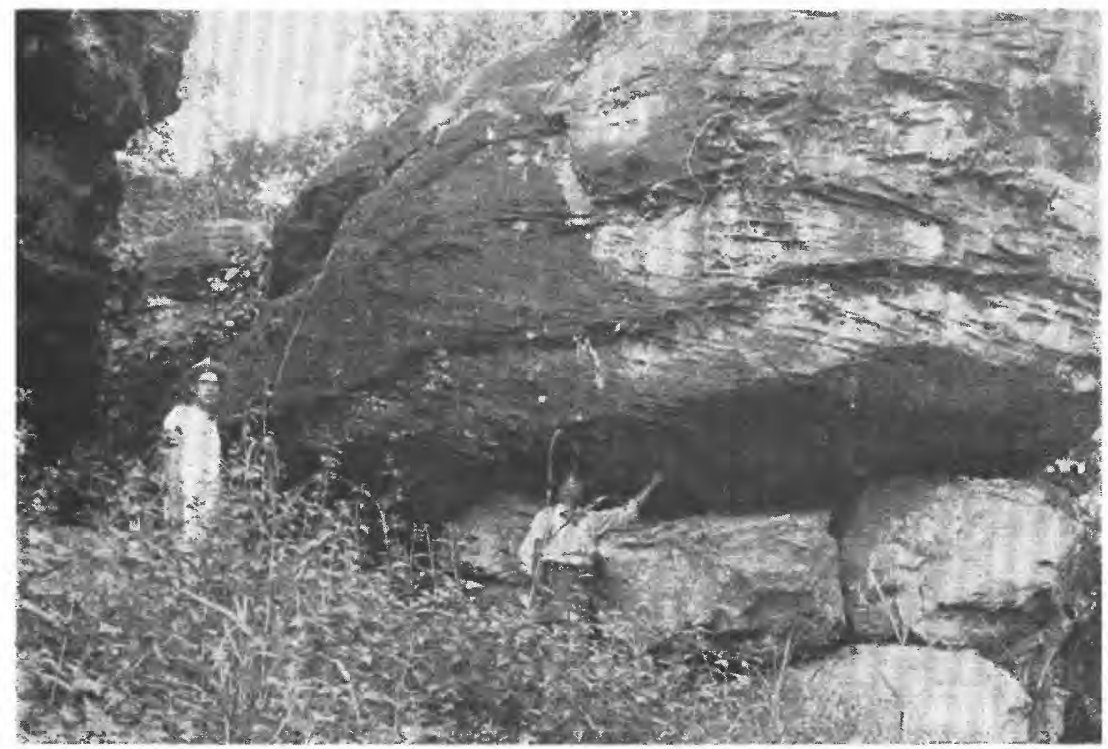

B. PHL PHAN MEMBER OF THE KHORAT SERIES EXPOSED NEAR KILOMETER 55 ON THE KHORAT-KABINBURI ROAD. 


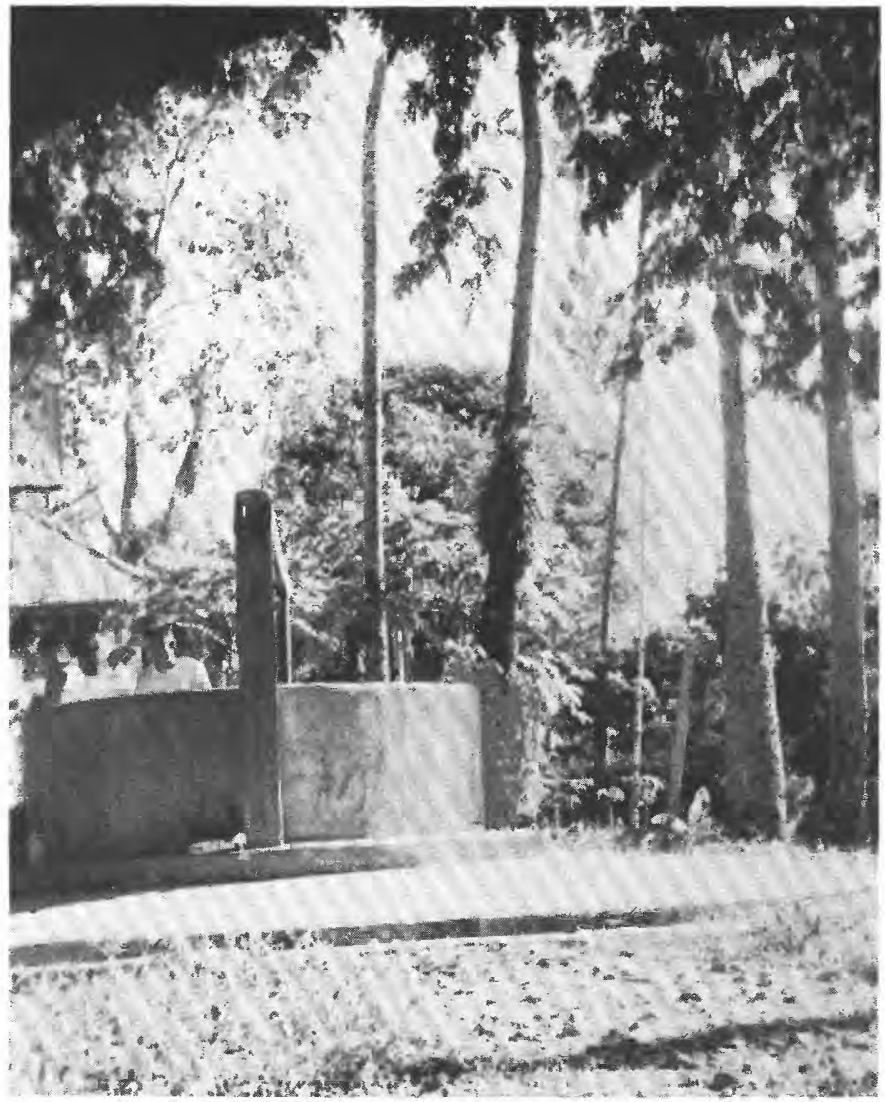

ROYAL WELL AT WAT THAT PHANOM.

Below concrete curbing, this dug well is lined with laterite brick. 
is about 5 kilometers southeast of Buriram in a northeastward-trending area that extends about 3 kilometers north of the railway. The flow about 20 kilometers southwest of Surin thickens from north to south and is not as extensive as the flow at Buriram. There are also outcrops of basalt southeast of Pradonchai, and northeast and northwest of Nam Om (Lee, 1923).

The basalt flows in the plateau are the final phase of igneous activities in the northeast region, and as they penetrated through the Khorat series, Jurassic sediments, and sediments of possible Cretaceous or younger age, they probably were extruded during the Tertiary.

\section{QUATERNARY TERRACE DEPOSITS AND ALLUVIUM}

Terrace deposits and alluvium occur adjacent to stream valleys and in some of the flat upland surfaces throughout the Khorat Plateau. These beds consist of lenticular clay, fine- and medium-grained sand, and small amounts of gravel. In some areas the beds comprise a thin veneer; in others, they may be as thick as 100 feet.

These beds were deposited by the ancient or present streams of the area as they meandered across the plateau. In general, they are fine grained; however, in a few areas adjacent to the Mae Nam Khong and to other large streams and rivers and in refilled channels of former streams, coarse sand and gravel were penetrated in wells. Shallow dug wells were reported to pass through lenses of sand and gravel at Ban Phai, Nong Khai, That Phanom, Nakhon Phanom, and Ubon.

Terrace or alluvial deposits observed in outcrops in interstream areas of the plateau were of fine-grained sand and silt and contained only small amounts of coarse-grained sand and gravel. Red or deepreddish-brown, vesicular laterite and lateritic conglomerate, composed chiefly of hydrated oxides of aluminum and iron, are associated with some terrace deposits. The laterite is often quarried in small blocks and used for construction material, including curbing for the dug wells of the area.

\section{GROUND WATER}

By P. E. Lamornaux, Jumchet Charaluavanaphet, and Phong Phan Na Chiengmai

\section{SOURCE AND OCCURRENCE}

The circulation of water from the sea to the atmosphere, to the earth's surface, and back to the sea by surface or underground routes, or directly to the atmosphere by evaporation and transpiration, is known as the hydrologic cycle. Water occurring beneath the water table, or ground water, is one phase of the complex movement of water in the hydrologic cycle. Water that falls on the land surface may be used by vegetation, it may evaporate, it may be carried away in surface streams and lakes, or it may seep into the soil and become 
subsurface water. Of the water seeping into the ground, a part is used to satisfy soil-moisture requirements, a part is held between the individual rock particles above the water table by molecular forces (capillarity) which counteract the force of gravity and hold or retard the movement of water, and a part ultimately seeps downward to the zone of saturation and fills the voids, cracks, and other openings in the rocks and becomes ground water. Water in this saturated zone moves slowly by gravity through the openings in the rocks down the slope of the water table, which is controlled by topography, type and geologic structure of the rocks, and the number, size, shape, and arrangement of the open spaces in the rocks.

The porosity, or percentage of open space in a rock, determines the amount of water a given rock will hold and is dependent upon the shape, arrangement, assortment, and degree of cementation and compaction of the constituent particles of the rock. The porosity of a rock is increased by the removal of mineral matter through solution by percolating water, and by fracturing of the rock that results in joints and other openings. The porosity of a rock determines only the amount of water a rock will hold, not the amount it will yield to wells. Some rocks, for example clay, may have a high porosity but will not yield an appreciable amount of water. A rock is described as being saturated when all its void spaces are filled with water.

The permeability of a rock is its capacity for transmitting water under pressure and is measured by the rate at which water is transmitted through a unit cross section under a unit difference of head per unit distance. Coarse-grained friable sandstone or coarse-grained sand and gravel, if well sorted, are very permeable and will transmit water readily. Finer-grained sediments, such as silt, clay, and shale, may have a high porosity, but, because of the small size of the openings, may have a low permeability or may be essentially impermeable.

\section{WATER TABLE}

The water table is the upper surface of the zone of saturation, except where that surface is formed by a bed of clay or other relatively impermeable body. The water table is neither a level nor a stationary surface, but has irregularities related to and comparable to those of the land surface. Its variations in slope and fluctuations in time are caused by such factors as topography, stratigraphy, and structure of the rocks, rate of withdrawal of water, and variations in rainfall. The water table may rise rapidly after a heavy rainfall, then decline gradually owing to discharge of water by evaporation and transpiration and flow from springs and wells. It is evident, therefore, that ground water is a dynamic resource continually being recharged and discharged in response to natural and artificial forces. 
Generally, there is but one zone of saturation, but in some areas the downward percolation of water is stopped by a layer of impermeable material, causing an upper zone of saturation above the true or main ground-water body. This upper zone is called a perched water body and its upper surface, a perched water table.

A typical water-table well in the Khorat Plateau area is the ancient dug well at Wat That Phanom which supplies adequate water to the village of That Phanom (see pl. 8). This well develops water from alluvial sand and gravel, and is reported to have been dug about 2,000 years ago. Recently the well was cleaned out and a new concrete curbing constructed at the top to keep out dirt and surface seepage. This well is near the Golden Pagoda at Wat That Phanom where the breast bone of Buddha is buried. The well is lined with laterite blocks, like many of the very old dug wells in the plateau, some of which were constructed during Cambodian rule. It is designated a royal well, and water from it and three other wells in Thailand is mixed and used to bathe the kings during their coronation ceremony.

\section{ARTESIAN CONDITIONS}

The rocks forming the Khorat Plateau consist chiefly of alternating beds of shale, sandy shale, and sandstone. The shale is relatively impermeable and the sandstone beds are believed to be permeable. These beds normally dip $10^{\circ}$ (930 feet per mile) or less toward the center of the plateau. The more permeable sandstone beds are potential water-bearers. Rainfall on the area in which the beds crop out seeps downward by force of gravity into these permeable beds of sandstone and becomes confined between the relatively impermeable beds of shale. The pressure exerted on the water in these confined aquifers by the weight of water at high levels in the same aquifers is known as hydrostatic pressure. When a well taps an aquifer downdip from its intake area, the pressure forces the water to rise in the well above the bottom of the overlying confining bed, and the well is said to be artesian. Figure 7 is a diagram showing artesian and water-table conditions. It represents in a general way the geologic conditions that exist throughout much of the Khorat Plateau. The height of a column of water that can be supported by the hydrostatic pressure at a given point in an aquifer is called the pressure head. The imaginary surface to which water will rise in tightly cased artesian wells is called the pressure-head-indicating, or piezometric, surface. When the pressure head is higher than the land surface the well will flow.

Ground water under artesian pressure probably occurs in several of the more permeable sandstone beds dipping from the margin to the central part of the Khorat Plateau. The most important are the medium- and coarse-grained sandstone beds in the Phu Phan and

$461197-58-4$ 


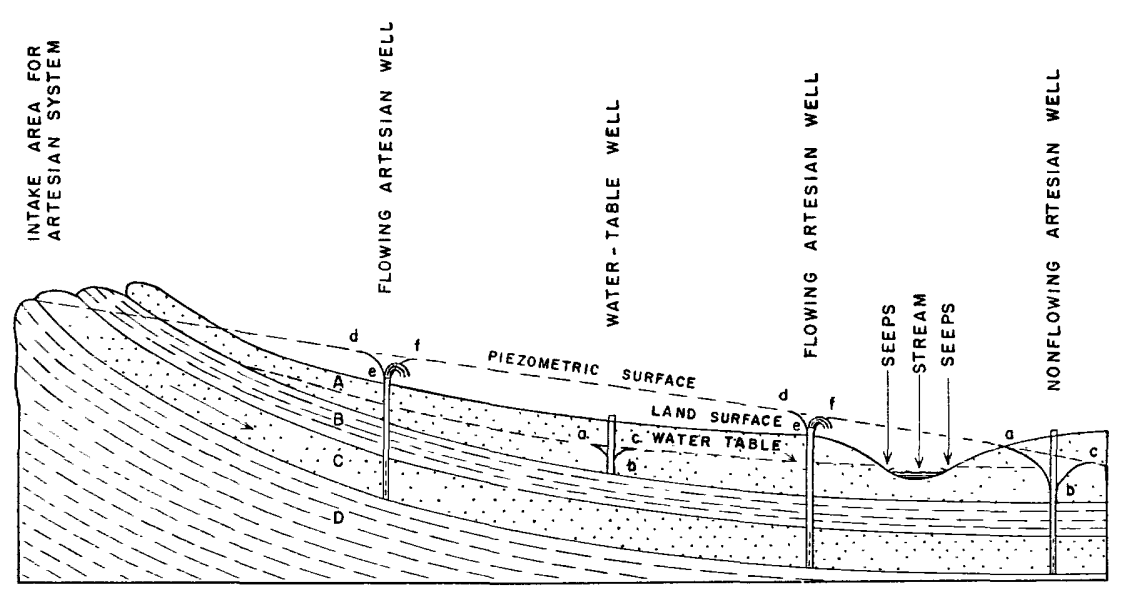

A. Permeable surficial material B. Upper confining bed

C. Artesian aquiter

D. Lower confining bed

$a, b, c$ Cone of depression coused by pumping

d, e,f Cone of depression caused by notural flow

FIGURE 7.-Schematic diagram showing artesian and water-table conditions.

Phra Wihan members of the Khorat series and the more permeable sandstone beds of the Jurassic system. Test drilling and test pumping are needed to determine the quantity and quality of artesian water available.

\section{RECHARGE}

The term "recharge" is used to designate the movement of water into ground-water reservoirs, which may occur in many ways. A ground-water reservoir may be recharged by rainfall on, or from streams crossing, its outcrop; by seepage from overlying or underlying beds; by induced recharge from nearby streams as a result of heavy pumping from wells; or artificially through wells, ditches, or spreading basins.

Ground-water reservoirs in the Khorat Plateau are recharged principally by infiltration of rainfall, directly into the underlying bedrock, or by seepage from streams and rivers where they cross or are adjacent to permeable bedrock or alluvial deposits. Recharge from streams can be sizable, and in parts of the plateau, geologic and hydrologic conditions are believed to be favorable for inducing recharge through development of wells of large capacity in areas underlain by alluvium.

Data from the Royal Department of Irrigation show the average annual precipitation in the Khorat Plateau is about 1,400 millimeters. Normally, persistent rains occur throughout the southwest monsoon season from May to October. During the remainder of the year the area receives relatively little rainfall (see figs. 8-11). The greatest ground-water recharge occurs during the monsoon season. The highest water levels in wells and the maximum amount of ground 


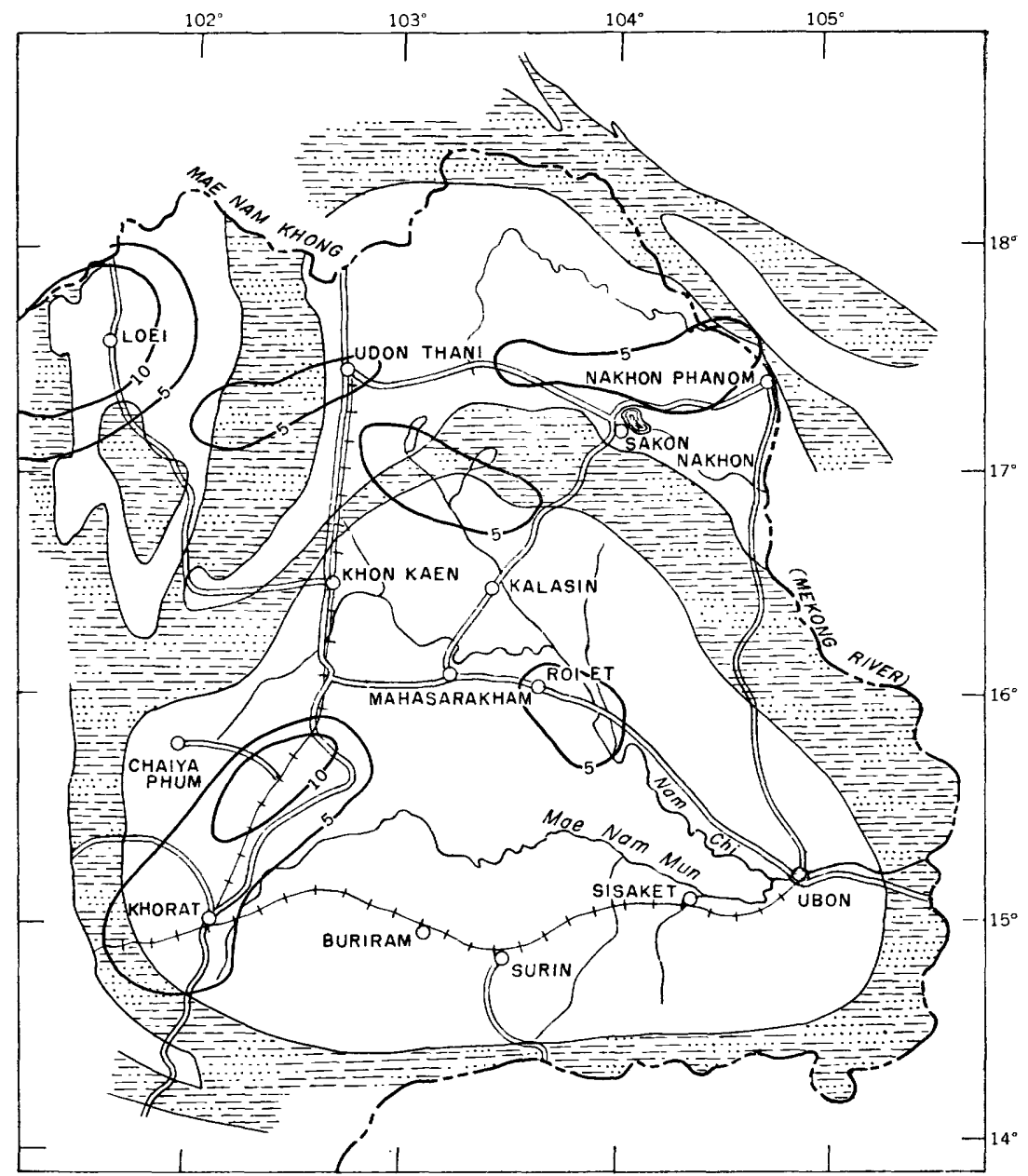

EXPLANATION

\section{$=0$ \\ Khorat series}

Upper part, coarse-grained sandstone; middle part, medium-grained sandstone; lower part, sandy shale

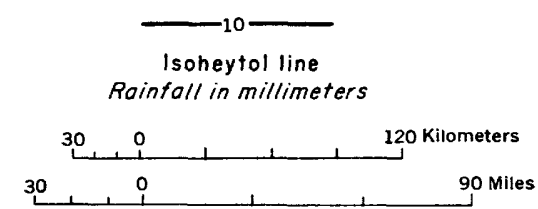

FIGURE 8-Map showing outerop of Triassic rocks and distribution of rainfall during Junuary in the Khorat Plateau. 


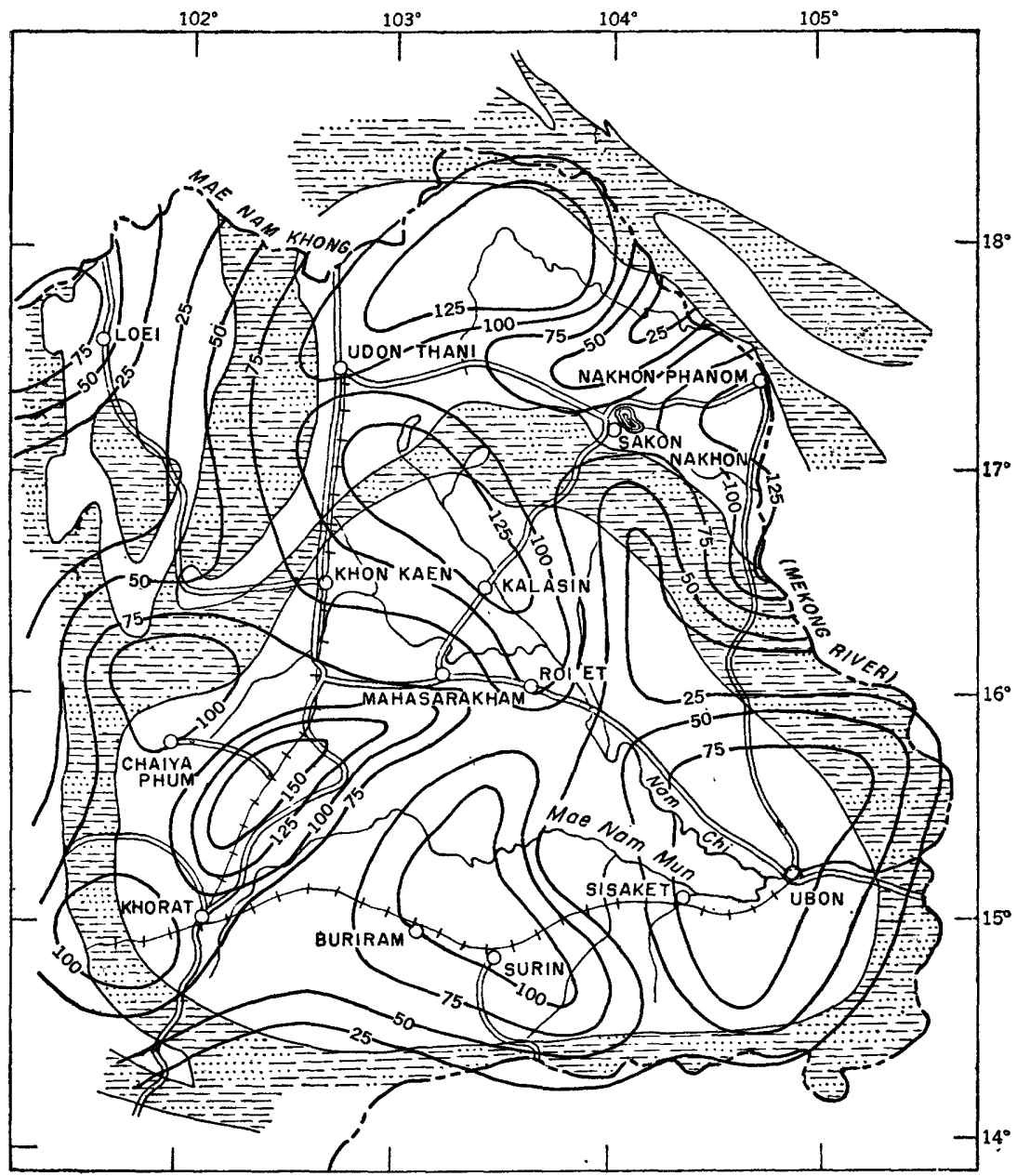

EXPLANATION

\section{$=0$}

Khorat series

Upper part, coarse-grained sandstone; middie port, medium-grained sandstone; lower part, sandy shole

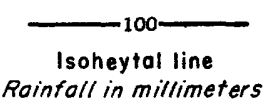

Roinfoll in millimeters

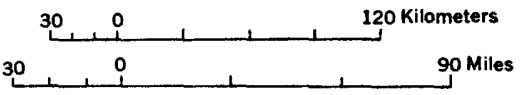

Ficure 9.-Map showing distribution of rainfall during April in the Khorat Plateau. 


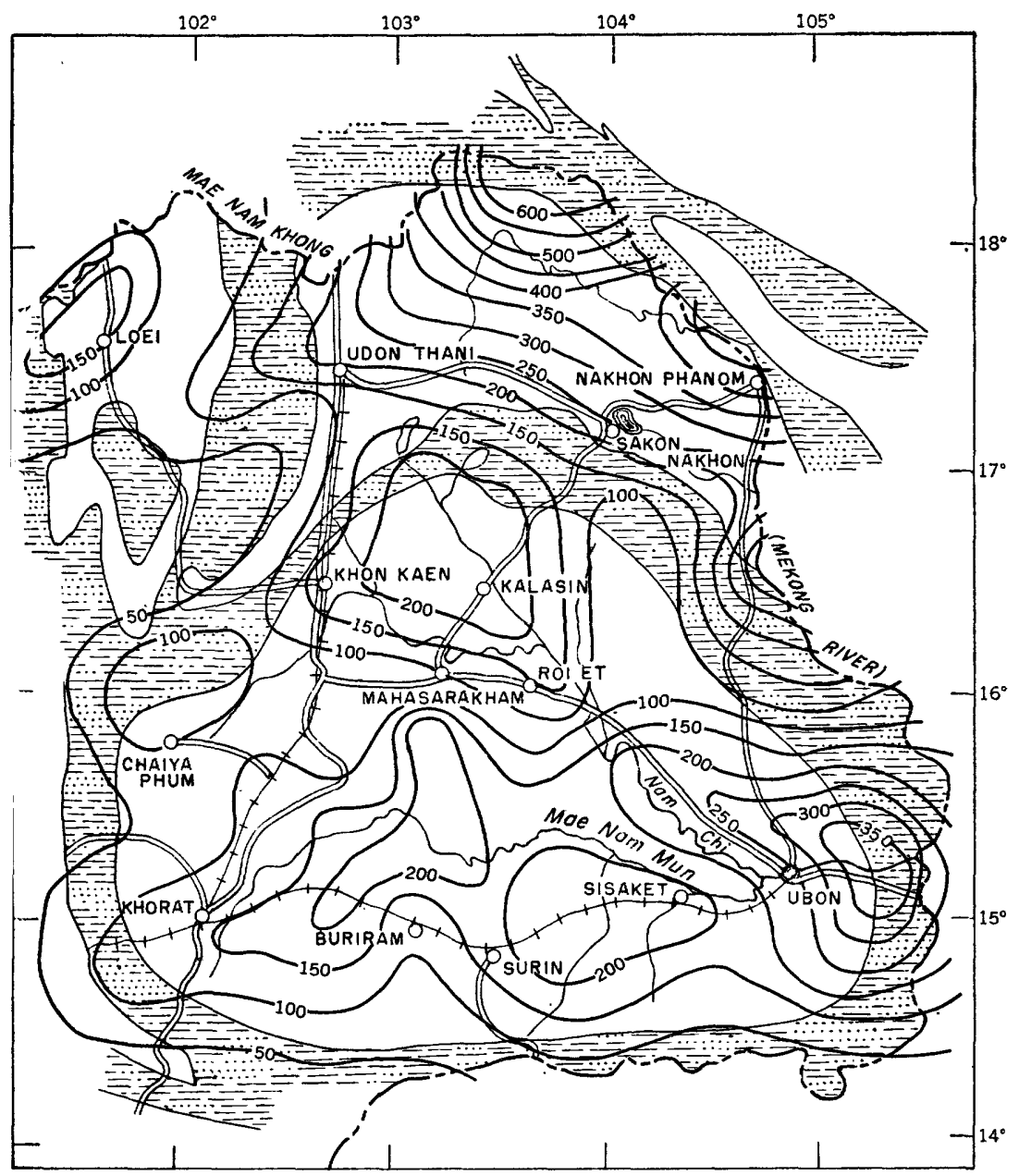

EXPLANATION

\section{$=0$ \\ Khorat series}

Upper port, coorse -groined sandstone;

middle port, medium-groined sand-

stone; lower part, sandy shole

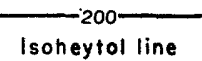

Roinfoll in millimeters

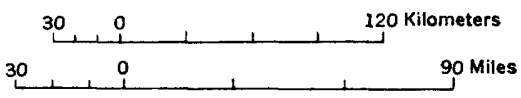

Fioore 10.-Map showing distribution of rainfall during July in the Khorat Plateau. 


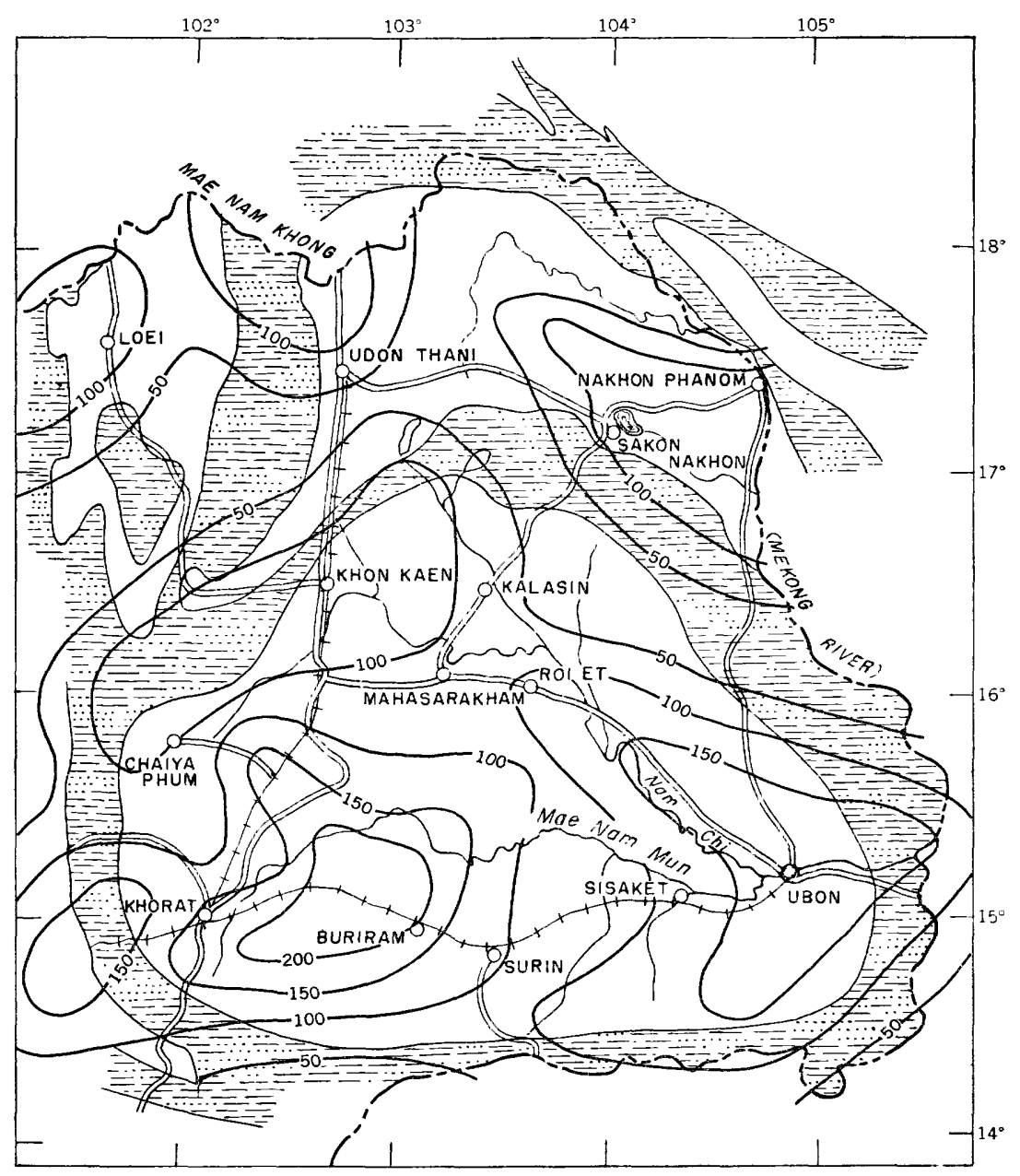

EXPLANATION

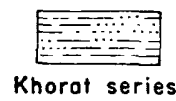

Khorat series

Upper port, coorse-grained sondstone; middle port, medium-grained sondstone; lower port, sandy shale

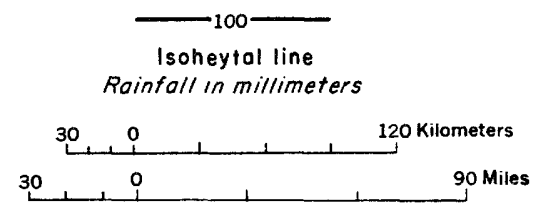

Figure 11.-Map showing distribution of rainfall during Octubrer in the KLorat Plateau. 
water in storage in the Khorat Plateau probably occur at the end of the rainy season in October. The fluctuation of water levels in wells that normally is to be expected would be a gradual rise from April or May to the latter part of October, and then a gradual decline to the lowest level of the year during the latter part of March or in April.

More detailed records on fluctuations of water levels in wells and precipitation are needed for an accurate interpretation of recharge conditions throughout the area. The amount of water percolating downward to the zone of saturation depends on several factors including the amount, duration, intensity, and distribution of rainfall, the character of the soil and exposed rocks, the structure of the rocks, the proximity of the water table to land surface, soil-moisture requirements, and the amount and type of vegetation.

The type and depth of soil in an area are strongly influenced by the geology. In areas underlain by clayey soils developed on relatively impermeable shale, conditions are poor for the infiltration of water to the underground reservoirs. Therefore, only slight recharge would be expected in the outcrop area of the predominantly shaly Phu Kadung nember of the Khorat series. There would be much greater recharge in areas underlain by sandy soil developed on the massive coarse-grained and in part poorly cemented sandstone beds of the Phu Phan member. These beds should act as a sponge absorbing rainfall and feeding it slowly downward into the underlying bedrock. Figures 8 to 11 show the outcrop of Triassic rocks and, by isoheytal lines, the distribution of rainfall during the four months shown. The outcrop of the Khorat series is the intake area for recharge to the sandstone beds. In January, the rainfall is very scanty, 10 millimeters or less throughout the outcrop area (see fig. 8). By April rainfall increases and throughout the outcrop area it ranges from about 25 to 100 millimeters during that month (see fig. 9). In July the rainfall ranges from less than 50 to 600 millimeters reaching 350 millimeters east of Ubon and 600 millimeters near the Mae Nam Khong (see fig. 10).. In October a major part of the plateau receives 100 to 150 millimeters of rain, the greatest amount of rain falling in the vicinity and immediately east of Khorat (see fig. 11). The isoheytal maps in general show that the rainfall on the outcrop of the Khorat series adjacent to the Mae Nam Khong in the eastern plateau, is greater than along the southern or western outcrop of these rocks.

Recharge from rainfall and from the streams may occur adjacent to streams where there are alluvial deposits. When the water table is below the level of the stream, or if pumping from a well or wells lowers the water table in such an area, the stream may furnish water to the adjacent alluvial deposits. Wells in alluvial deposits at Chaiyaphum, Nakhon Phanom, and Ubon probably are replenished in part from the 
nearby streams, as their owners have noticed that the water levels in the wells rise and fall with the water levels in the streams.

\section{RECOVERY OF GROUND WATER}

The withdrawal of water from a well produces a difference in head between the water inside the well and in the surrounding aquifer, causing a depression in the water table or piezometric surface. This depression, in the approximate form of an inverted cone with its apex at the well, is known as the cone of depression or cone of influence (see fig. 7) and the corresponding area affected is known as the area of influence. The larger the discharge of a well, the deeper is the cone of depression. For a short time after pumping begins, the water level drops rapidly and most of the water that is pumped comes from those parts of the aquifer comparatively close to the pumped well. However, as pumping continues, the water level in the well declines more slowly because the expansion of the cone of depression permits water from greater distances to percolate toward the well. The water level will continue to decline, but at a decreasing rate, and the cone of depression will eventually extend to the limit of the formation or until sufficient recharge or discharge is intercepted to halt its development. When pumping is stopped, the process is reversed; the water level in the well rises rapidly at first and more slowly in the later stages of recovery.

The specific capacity is an index to the productivity of a well and is defined as the rate of yield per unit of drawdown. It is determined by dividing the discharge of the well by the drawdown.

\section{DUG WELLS}

Dug wells in the Khorat Plateau are generally 3 feet or more in diameter, range from a few feet to generally not more than 50 feet in depth, and are excavated with hand tools. Dug wells furnish a large part of the ground water used in the plateau, and when deep enough generally furnish an adequate year-round supply of water for domestic and limited stock use. These wells may or may not have a curbing from top to bottom, depending on the character of the material penetrated. If a well is started in a compact clay or sandy clay, and enters a water-bearing sand, curbing is used only in the bottom of the well to keep the sand from caving. If the well is dug in loose material, such as sand and gravel, a curbing from top to bottom is necessary. Curbing in wells in the plateau is made of blocks of laterite, wood, brick, stone, or concrete. Inadequately curbed dug wells may be polluted by seepage from the surface.

\section{BORED WELIS}

Bored wells excavated with hand or power augers are usually 4 to 6 inches in diameter and range from 10 to 100 feet in depth. Light 
metal casing is installed in these wells, perforated casing or screen being set opposite the water-bearing bed. Bored wells are practical in areas of unconsolidated or relatively soft sedimentary rocks. Most bored wells in the Khorat Plateau are equipped with handoperated pitcher or deep-well cylinder pumps and are used for domestic and stock supplies.

\section{DRILLED WELLS}

A drilled well is excavated by either a percussion or a rotary drilling rig. Drilled wells generally have galvanized-iron, wrought-iron, or steel casing, with one or more screens set opposite water sands or gravels. Ordinarily, where consolidated rock such as sandstone and limestone occur, casing is set to the top of the rock and no screen is used.

\section{SPRINGS}

Most of the springs in the Khorat Plateau are gravity or seep springs that occur along the contact between permeable sandstone beds and underlying relatively impermeable sandy shale or shale beds. Water percolates downward through the permeable sandstone by the force of gravity until it reaches the zone of saturation. It then moves laterally until it reaches the outcrop where it issues as a spring. Springs of this type in the Khorat Plateau yield relatively small amounts of water, ranging from less than a gallon to about 10 gallons per minute.

A large spring at Nong Han is believed to issue along a fault plane and the water is discharged under artesian pressure. The Nong Han spring was not measured because the water discharges over a large seepage area. At one of these discharge points a wood curbing has been built around a basin dug down into the ground. This water was clear and of good quality. The spring is reported to flow all the year and would be an excellent source of water for the area.

\section{POTENTIAL RECOVERY OF GROUND WATER IN THE KHORAT PLATEAU}

A coordinated effort by the Royal Department of Health and the Office of Health of USOM to provide adequate amounts of sanitary water is directed toward the development of shallow bored wells in the Khorat Plateau. These wells are bored with jeep-mounted power augers, and completed with 6 -inch casing, 6 -inch screens, and handoperated cylinder pumps (see pl. $9 A$ and $B$ ). These wells, though satisfactorily completed, have created a maintenance problem because of lack of replacement parts. In many areas of the plateau people believe the water from the wells is highly mineralized and continue to use water from surface pits, ponds, and canals (see table 2). An educational program and encouragement are needed in the use of water from properly constructed and maintained wells. 
Only a small part of the available ground water in the area is developed. Additional sources of water are the soil and weathered bedrock through the area, the alluvial sand and gravel deposits adjacent to streams, and the dipping sandstone beds that contain water under artesian pressure.

\section{WATER FROM SOIL AND WEATHERED BEDROCK}

Water for domestic and stock needs can be obtained at nearly every amphoe, tambon, and muban from shallow dug or bored wells developed in the skeletal soil and weathered bedrock. These wells generally need not be more than 60 feet deep; however, they must reach a depth below the lowest water level of the year. According to the existing rainfall data this low water level probably occurs in March at the end of the dry season. In the small villages an appropriate number of properly constructed shallow wells would be sufficient as a source of supply. In addition, an elevated tank should be constructed to store the water and a pipeline system laid out to distribute the water to convenient places within the village. Elsewhere such development may not be practical, and dug or bored wells with casing and protective aprons and pumps could be installed to supplement existing water supplies.

\section{WATER FROM ALLUVIUM}

Erosion by wind, rain, and streams has attacked the rocks in the plateau and through long periods of geologic time has broken them up and carried them away to be deposited elsewhere. Streams have cut back and forth across the plateau, sometimes abandoning channels for newer and easier routes of flow. The deposits of these streams consist of clay, sand, and gravel. Recharge into these alluvial deposits from rainfall and, at times, the streams themselves is rapid and storage of water underground is large. These deposits can be located by study of aerial photographs, or by air reconnaissance, and defined by shallow test drilling. Where present, alluvial beds should be an important source of water for municipal, industrial and, in some instances, irrigation supplies. Numerous deposits of this type were indicated from data obtained from the well inventory for this report. Wells develop water from alluvium in the vicinity of Phimai, Ban Phai, Udon Thani, Nong Khai, Nakhon Phanom, That Phanom, Ubon, Yasothon, and Selaphum.

Future development of shallow ground water in the area would be facilitated by adequate ground-water investigations, which would include: (1) geologic studies to determine the thickness, character, and distribution of shallow water-bearing beds; (2) a detailed inventory of wells and sampling of water for chemical analysis to determine the quality of water; (3) an observation-well program in the plateau to determine the fluctuation of the water table over a period of years to 
aid in choosing the depth to dig or drill wells, estimating additions to or withdrawals from ground-water storage, and in determining whether local withdrawals had reached the practical limit; (4) preparation of maps of heavily populated areas showing the chloride content of the water to show areas of pollution of ground-water reservoirs; and (5) test drilling to define water-bearing alluvial deposits. An educational program should be coordinated with these investigations and the construction of wells to show the people how to use and maintain the wells properly.

\section{WATER FROM DIPPING SANDSTONE BEDS}

In the Khorat Plateau, only four wells have been drilled; all failed to develop potable water. Three were drilled at Khorat and were either dry or yielded a small amount of highly mineralized water. The fourth well at Bua Yai, drilled in 1954 by the State Railway of Thailand, was unsuccessful. These wells were not drilled deep enough to penetrate sandstone of Triassic age which may be a potential source of artesian water in the area.

The sandstone, shale, and limestone beds in the Khorat Plateau dip in general from $5^{\circ}$ to $10^{\circ}$ inward from the rim to the central part of the basin. Of these, the granular and friable medium- and coarsegrained sandstone beds are potential aquifers. They receive recharge from rainfall in their outcrop area near the rim of the basin and should be a source of ground water under artesian pressure for water moving down the dip in the sandstone becomes confined between relatively impermeable layers of shale. In the middle of the basin these potential aquifers will be relatively deep and the wells drilled into them probably will be costly to develop. In addition, the water may be highly mineralized. Around the outer margin of the basin, possibly within a belt as wide as 30 kilometers, the more permeable sandstone beds could be penetrated in wells of moderate depth and may yield potable water.

In addition to the deeper-lying, older sandstone beds, some of the more permeable sandstone beds that form the capping layers of rock in the central part of the plateau may be a source of artesian water. Where topography, geology, and structure are favorable, as for example in the vicinity of Wat Makham Thao near Khorat, shallow bored or drilled wells will flow. The well at Wat Makham Thao flows during only a part of the year, at the end of and immediately after the rainy season when artesian pressure is greatest (see pl. 9A).

Detailed ground-water studies coordinated with controlled test drilling are needed to provide a more detailed knowledge of the geology and occurrence of ground water and to outline favorable areas for development. Initial work should be directed to the outer margin of the plateau and extended inward to delineate where water of good 
quality can be developed. Test drilling, for example, could start near Pakthongchai, Phibun, Ban Boeng, and Khon Kaen. Studies should include establishment of observation wells for collection of data on fluctuations of artesian head and flow. Pumping tests are needed to determine potential quantities of water available to wells and proper spacing between wells, and geologic studies are needed to determine location of aquifers and their structure.

\section{QUALITY OF WATER}

Water that falls as rain contains only small amounts of dissolved matter, but upon reaching the ground it begins to dissolve minerals from the soil and rocks. The most common substances dissolved in ground water are salts of the metals sodium, potassium, calcium, magnesium, iron, and aluminum. These are derived from the soil, and from the rocks beneath by solution. The amount and kind of dissolved matter contained in ground water difier greatly from place to place, depending upon the extent to which carbonic and organic acids are supplied to the water by the soil zone, upon the types of rocks through which or over which the water moves and the length of time that the water is in contact with them, and the temperature of the water. Some rock formations contain easily soluble salts such as chlorides. As a result, water from such formations may be highly mineralized. In contrast, another formation may be composed of relatively insoluble minerals, and water from it will be low in mineral content. Calcium is present in nearly all ground water. This is because it is easily dissolved from deposits of limestone, gypsum, dolomite, and other rocks by water acidulated with carbon dioxide. Other constituents commonly present in ground water include iron, silica, sodium, potassium, bicarbonate, sulfate, chloride, fluoride, and nitrate.

The chemical quality of water may limit its use for domestic or municipal supply, as outlined in the U.S. Public Health Service Drinking Water Standards (1946), or for irrigation or industrial use. By these standards, domestic and municipal supplies preferably should contain not more than 500 parts per million (ppm) of dissolved solids, $250 \mathrm{ppm}$ of chloride, $250 \mathrm{ppm}$ of sulfate, and $125 \mathrm{ppm}$ of magnesium. Fluoride in drinking water in excess of $1.5 \mathrm{ppm}$ may cause permanent mottling of tooth enamel if such water is used during the period of calcification of the teeth in childhood (Dean, 1938). However, a small fluoride content raduces the incidence of tooth decay when the water is used by children.

Various industries require water of a certain quality. The hardness is of primary importance. It is indicated in water by its soap-con- 
suming properties or the amount of soap required to make a permanent lather. Hardness is usually computed as the calcium carbonate equivalent to the concentration of calcium and magnesium in the water, as calcium and magnesium ions are the constituents that cause most hardness. Water having a hardness of more than $80 \mathrm{ppm}$ if used in a pressure boiler may cause a scale, and water used in high-pressure boilers and turbines (over 400 psi) must have nearly zero hardness. Commercial laundries, textile mills, and bleaching, dyeing, soap, and tanning industries require soft water for efficient production. The content of iron (or iron and manganese together) according to the U. S. Public Health Service Drinking Water Standards should be less than 0.3 ppm in water for municipal supplies, and should be even lower in water for many industrial uses. Ground water used for air conditioning and other cooling installations must have a relatively low, uniform temperature.

Ground water dissolves chloride from rocks through which it percolates and locally may come in contact with salt deposits or receive waste products from surface sources that increase the chloride content. Chlorides in large quantities affect the suitability of water by giving the water an objectionable salty taste. Chloride salts may increase the corrosiveness of the water. Chloride salts are very troublesome in irrigation waters, and high percentages of sodium chloride and other sodium salts are likely to have an adverse effect on soils or on agricultural crops.

The $\mathrm{pH}$ of the water (logarithm of the reciprocal of the hydrogen-ion concentration, in moles per liter) is an index to its corrosiveness. A knowledge of corrosiveness is important in planning use of water in boilers and machinery and its distribution through pipes.

Samples of water were collected from 145 wells and springs in the Khorat Plateau and analyzed by Mrs. Saman Buravas, chemist, Royal Thai Department of Mines, for $\mathrm{pH}$, hardness, and chloride. These data are listed in table 2. The chloride content of water from wells in the Khorat Plateau varies widely, ranging from less than 10 to about $4,500 \mathrm{ppm}$. The hardness of water also is variable, ranging from less than 10 to $9,440 \mathrm{ppm}$. In general, however, the water is only moderately hard, averaging less than $75 \mathrm{ppm}$.

Future studies of the chemical characteristics of water throughout the plateau should outline in detail areas where the water is high in chloride, as these are areas where potable water will be scarce. These areas also may act as sources of contamination for fresh-water beds in adjacent areas under conditions of development. In addition, studies of these areas will facilitate geochemical interpretation of the occurrence and movement of ground water. 


\section{LOCAL SUPPIIES}

As a part of this study an inventory of 158 wells and springs was made and data on their location (shown on plate 2), depth, yield, and type of water-bearing bed are recorded in table 2. These wells were chosen as representative of the shallow dug and bored wells in the Khorat Plateau.

Khorat (Nakhon Ratchasima) has the second largest population in the Khorat Plateau, and its public water supply system, built by the Municipal and Public Works Department, Ministry of Interior, takes water from the Lam Takhlong canal 1.5 kilometers north of the village. Twenty-five representative wells were studied in the vicinity of Khorat (wells 1-25). Shallow ground water is developed throughout the area from wells that are 15 to 80 feet deep, depending on the altitude of the land surface. Shallow wells in the municipal area and vicinity yield water that is hard and high in mineral content. Of 30 wells bored by the Department of Health in the area, only a few yield potable water. Chloride is the chief anion and appears to decrease with distance from the more densely populated areas, suggesting contamination from surface wastes. The temperature of water from wells in this area ranged from $81.5^{\circ} \mathrm{F}\left(27.5^{\circ} \mathrm{C}\right)$ to $85^{\circ} \mathrm{F}$ $\left(29.4^{\circ} \mathrm{C}\right)$; the chloride content, from 16 to $2,800 \mathrm{ppm}$; and the hardness, from 16 to about $1,170 \mathrm{ppm}$.

The engineers of the State Railway of Thailand drilled two wells, each about 500 feet deep, in the railroad yard at Khorat in an attempt to obtain water suitable for locomotive boilers. The wells were drilled through a series of unconsolidated clay, sand, and gravel beds, below which were beds of sandstone and shale and a few thin layers of salt. Less than $10 \mathrm{gpm}$ was yielded by either well, and the water was reported to be highly mineralized. Brackish water was reported at depths of 98,266 , and 380 feet. Both wells were filled and abandoned. The logs of 2 wells drilled at the military compound at Khorat and the log of one of the wells at the railroad yard at Khorat (well 17) are given on pages 25 and 26.

In Amphoe Phimai four auger-bored wells (wells 18-21) with screens set opposite sand from 37 to 48 feet, yield an adequate supply of water of good quality at Kulno School and the first-aid station. This water has a temperature of $83^{\circ} \mathrm{F}\left(28.3^{\circ} \mathrm{C}\right)$, is moderately hard to hard, and has a chloride content of 180 to $220 \mathrm{ppm}$. Additional wells could be dug or drilled in the area to produce more water. Adjacent to the river it may be possible to develop wells in alluvial deposits.

At Amphoe Ban Phai, dug wells adjacent to the stream yield high-chloride water; however, a few dug wells, distant from sources of contamination, such as at Anamai Ice Factory (well 27) and the 


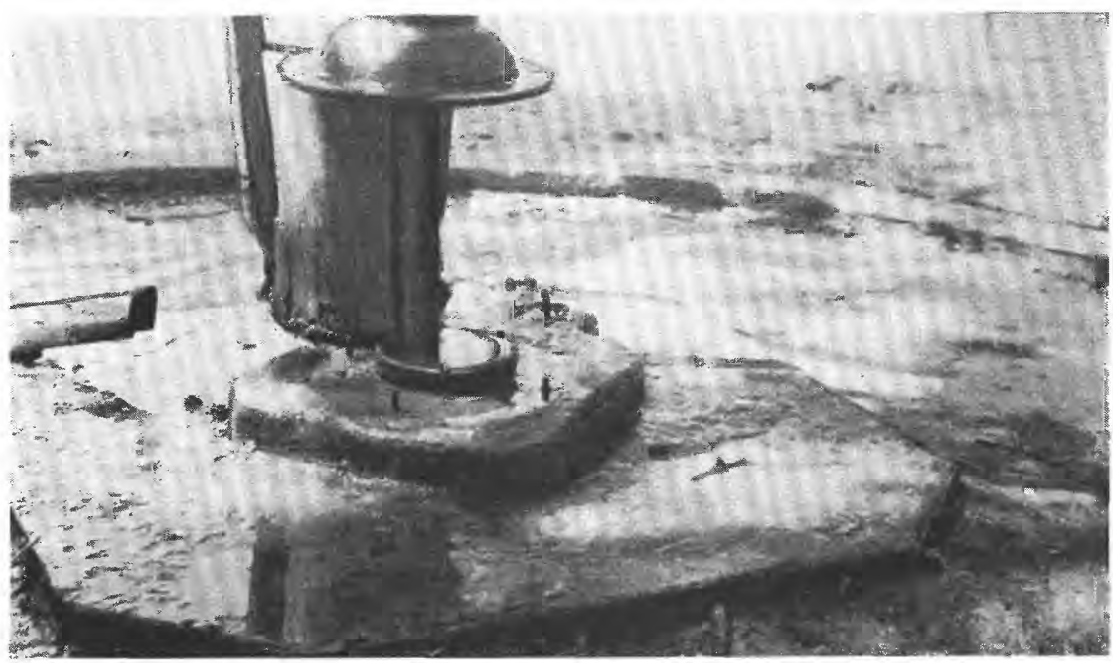

A. WELL AT WAT MAKHAM THAO NEAR KHORAT, BORED BY THE ROYAL DEPARTMENT OF HEALTH, THE ONLY FLOWING WELL IN THE KHORAT PLATEAU.

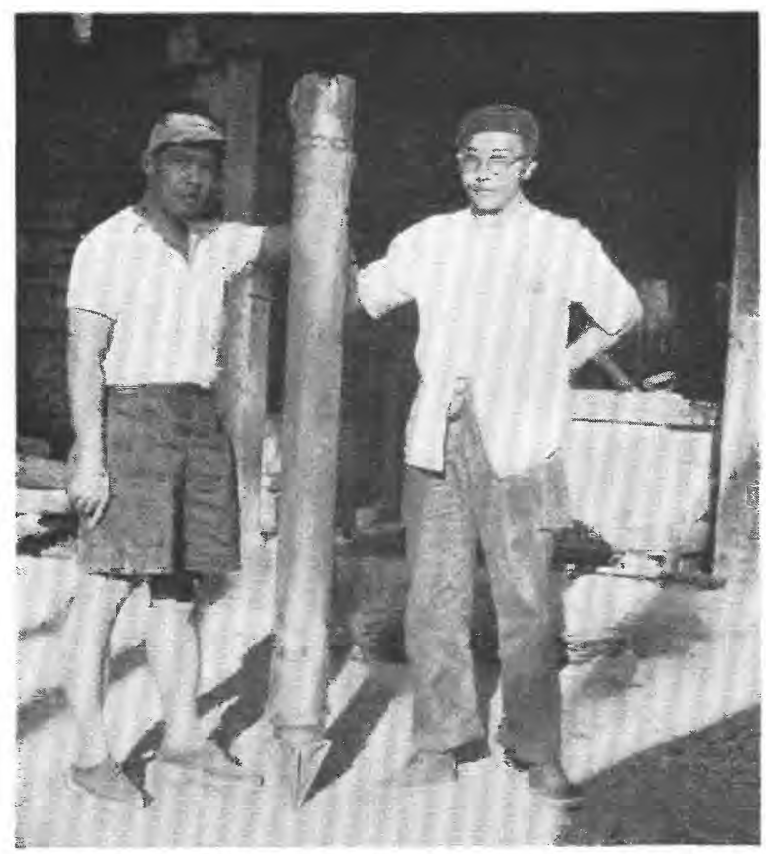

B. SCREEN, 6 INCHES IN DIAMETER, USED WITH PLASTIC CASING IN CONSTRUCTION OF SHALLOW BORED WELLS, AS PART OF THE PROGRAM OF THE ROYAL DEPARTMENT OF PUBLIC HEALTH AND USOM FOR DEVELOPMENT OF SHALLOW WELLS. 

Royal Highway Department compound (well 150), yield fresh water. The well at the ice factory, 12 feet deep and 10 feet square, is equipped with a pump powered by a gasoline engine. The quantity and quality of the water are satisfactory for the manufacture of ice. There are many private dug wells at Ban Phai, nearly every store having a well. Records of 5 wells, 26-29 and 150, are given in table 2. Typical of these is the well at Kow U Ha store (Shell Gas Station) (well 29), which is 14 feet deep and yields water having a temperature of $79.5^{\circ} \mathrm{F}$ $\left(26.4^{\circ} \mathrm{C}\right)$ and a chloride content of $512 \mathrm{ppm}$. The water from these wells is used principally for washing. Shallow test drilling to outline alluvial deposits adjacent to the streams at Ban Phai would be practical for the development of wells that might yield $50 \mathrm{gpm}$ or more each. Water of better quality, lower in chloride, could be developed from wells distant from sources of pollution.

\section{KHON KAEN}

At Khon Kaen the source of water for the new municipal supply under construction will be the Nam Chi, 6 kilometers from the village. At present, local water supplies are obtained from surface ponds and from dug wells. About 20 wells have been bored by the Department of Health in the area; however, most of them are not in use owing to mechanical trouble with the pumps. The water from wells in the more densly populated areas is slightly salty to very salty, some wells yielding water containing as much as $4,000 \mathrm{ppm}$ of chloride. This highly mineralized water is used only for washing. Some wells (wells $34,35,39$ ) distant from sources of pollution, yield water of good quality that is relatively low in dissolved minerals. There are some very good dug and bored wells 20 to 60 feet deep near Khon Kaen air field such as well 33, which are developed in alluvial sand and gravel deposits. Much additional water could be developed in that area, but development should be based on detailed ground-water investigations including an inventory of wells and collection and analysis of water samples to outline areas where water is low in dissolved solids and chloride. These data could be supplemented by shallow test drilling to outline areas underlain by water-bearing alluvial deposits. Large supplies of ground water may be available from deposits of sand and gravel adjacent to and recharged by the Nam Chi.

\section{UDON THANI}

Udon Thani, 60 kilometers north of Khon Kaen, is the third largest town in the region. There are more than 30 wells bored by the Department of Health and many private dug wells in and near the village. Ground water of good quality generally can be obtained from wells on higher ground; however, many wells on low ground, especially those below and near impounded surface-water reservoirs 
and in or adjacent to areas of concentrated population, yield highly mineralized water. Wells yielding water high in chloride content are used for washing. The best bored wells in the area are at the airport of Nong Khon Kwang (well 82) and railway station of Kum Kling (well 65), are 30 to 50 feet deep, and develop water from a pebbly bed as much as 10 feet thick. The water is of good chemical quality and these beds are favorably situated for recharge. There are many dug wells in the rural area about the village that supply adequate domestic supplies. A municipal waterworks system is being constructed for Udon Thani by the Municipal and Public Works Department. It includes a pumping station and filtration plant on the Nam Luang about 5 kilometers north of town. In this area, as at Ban Phai, Khon Kaen, and Khorat, a more detailed inventory of wells with special emphasis on the chemical quality of water should be made. Isochlor maps would outline areas where water is high in chloride; test drilling would delineate areas underlain by water-bearing sand and gravel beds; and aquifer tests would show the quantities of water available from wells in the area.

\section{NONG KHAT}

Near Nong Khai, on a terrace of the Mae Nam Khong, adequate water from shallow dug wells, 30 to 50 feet deep in alluvial sand and gravel, supply municipal and domestic needs. Many successful wells have been dug or drilled on the grounds of the temples and have supplied water for public use for more than a hundred years. In some of these wells water levels are reported to rise and fall with the level of water in the river. Much additional ground water of good quality for municipal, industrial, and agricultural use can be developed from alluvial sand and gravel deposits in the area. Four wells were recorded in this area (wells 76-79).

\section{NONG HAN}

At Nong Han, east of Udon Thani on the Sakon Nakhon road, wells in the business section of the village yield water moderately high in chloride (well 88). Seepage from polluted surface wastes is the chief cause of the mineralization, as wells farther from the village yield water of good quality. A spring (see no. 89, table 2) at the southwest edge of the village is an excellent year-round source of water and could easily be developed for use by the village and possibly for irrigation. The flow of the spring could not be measured because of the widespread area of discharge. It is believed that a moderately large quantity of water is available from the spring. The water from this spring had a temperature of $78^{\circ} \mathrm{F}\left(25.6^{\circ} \mathrm{C}\right)$, a hardness of 80 $\mathrm{ppm}$, and a chloride content of $82 \mathrm{ppm}$. 
SAKON NAKHON

At Sakon Nakhon on the shore of Nong Lahan, the largest freshwater lake in Thailand, many dug wells yield water low in chloride content. Wells in the municipal area are mineralized and not used for drinking. The people obtain their drinking water from a city reservoir called Sa Traphang Thong and from ponds near the lake. Even though ground water would be safer to use, if taken from wells properly located and constructed to guard against pollution, the use of water from wells is not popular in the area as the people prefer the taste of water from ponds or from the lake. Wells 80 to 87 were recorded in this area.

\section{AMPHOGS NAKHON PHANOM, MUKDAFAN, AND THAT PHANOM}

In Amphoes Nakhon Phanom, Mukdahan, and That Phanom water supplies are from dug wells developed in the alluvial deposits of the Mae Nam Khong. Most of these wells are 25 to 35 feet deep, have brick or laterite-block curbing, and are developed in sand and gravel. Three wells bored by the Department of Health (wells 98, $102,103)$ at the school and temple compound at That Phanom, all about 45 feet deep, yield fresh water for public use. A large dug well at the temple has been in use for more than 2,000 years. It is one of the sacred wells, and the water is drawn from it to bathe each new king at his coronation (see fig. 7).

\section{UBON}

The largest city in the Khorat Plateau is Ubon, on the bank of the Mae Nam Mun. The Department of Health has bored 40 wells in the area; 25 yield fresh water. There are also hundreds of dug wells that supply water to nearly every household and business. In the rural districts of Changwat Ubon at Amphoe Det Udom a year-round water supply is obtained from dug wells about 10 feet deep, and at Amphoe Phibun on the south bank of the Mae Nam Mun water supplies are obtained from dug wells and ponds. Throughout the area adjacent to the Mae Nam Mun, alluvial deposits can afford much additional water supply to shallow dug and bored wells 10 to 60 feet deep. Water from the wells recorded in this area (107-113 and 118-121) is, in general, low in chloride content, ranging from 4 to $190 \mathrm{ppm}$. Hardness ranges from 2 to $412 \mathrm{ppm}$. Knowledge of ground-water conditions in the area indicates that at least some of the water-bearing sand and gravel beds are recharged by the Mae Nam Mun.

\section{ROAD FROM UBON TO BAN PHAT}

The road from Ubon to Ban Phai crosses the center of the Khorat Plateau. Water supplies in this area are from shallow dug wells and ponds, nearly all of which become dry in the dry season. A few 
wells in this area are dug deep enough to provide a year-round supply, and many additional wells could be put down by digging, boring, or drilling that would be equally successful. There are properly constructed dug wells in villages such as Amphoes Khuang Nai (well 132), Lumphuk (well 133), Yasothon (well 134), and Thawatburi (well 136). The best well in the area is at Amphoe Khuang Nai. This well is 5 feet in diameter, 20 feet deep, and has a concrete curbing and apron. It is covered by a roof as partial protection against windblown dust and debris.

\section{MAHASARAKHAM}

Within the municipal area of Mahasarakham there are 32 dug wells which supply a major part of the water for the village. Most of these wells are not cased and have little protection against entrance of surface pollution. It was reported that, of about 100 private wells in the area, only 10 yield potable water. Chemical analyses of the water of 7 wells recorded (143-149), however, show a high chloride content only in water from wells in the older areas of town where the population is concentrated. East of town along the highway to Roi Et there are many wells about 20 to 30 feet deep that supply water whose taste is acceptable to the people. (Well 144 was recorded.) Along the highway west of town to the Mae Nam Mun, wells range in depth from 20 to 35 feet (well 146, for example). Nearly all these wells supply year-round water for drinking, washing, and some irrigation of gardens. Some of the wells are believed to obtain water from sand deposits of the Mae Nam Mun, and further study leading to the development of larger quantities of ground water in this area would be worthwhile. In the central part of the village of Mahasarakham there are many wells 25 to 45 feet deep (wells 143 and 145 were recorded), some of which are reported to be salty and some reported to become dry in the dry season. These wells are used for washing. One well at the Provincial hospital (see well 145, table 1) at the southern edge of this area is constructed properly with concrete curbing and cover and yields water low in chloride content and hardness. This well is equipped with a pump that lifts water to an elevated storage tank from which it is distributed.

The Municipal and Public Works Department is developing the Huai Kha Khang, 5 kilometers north of the village of Mahasarakham, as a source of municipal water supply. It is believed that properly located and constructed wells would afford much additional ground water in the area. Exploration to locate alluvial sand and gravel beds would be practical, as it was reported that course sand and gravel deposits were penetrated in wells at the airfield of Mahasarakham (well 146) and in the area adjacent to the Mae Nam Mun. 


\section{ROI ET}

At Roi Et, there has been a shortage of water during the dry season for many years. Near the center of the village is a large surface-water reservoir which is used as a source of supply; however, it becomes dry during the summer. Thus during the latter part of the dry season, surface water is not available. However, dug wells just outside the canal that nearly encircles the village produce a yearround supply of potable water. There are good wells immediately adjacent to and on both sides of the canal along the southern margin of the village (well 141, for example). These wells are in areas where sewage from a concentrated population does not have easy access to the shallow ground water. To supplement existing supplies, the Municipal and Public Works Department is planning construction of a municipal water system that will pump water from the Nong Yama, 3.8 kilometers southeast of town, to a filtration plant for distribution throughout the central part of the village.

\section{SISAKET}

In Sisaket, six dug wells supply a part of the water requirements of the area (wells 126 to 131); the rest of the local supplies are taken from klongs and ponds. All six wells yield fresh water containing less than $126 \mathrm{ppm}$ of chloride; however, three wells are used only as a source of wash water. Wells in the area range in depth from 15 to 25 feet, and all become dry during the dry season. Most wells are developed in laterite or weathered clay; however, the well at the electric plant (well 131) is reported to be developed in a sand and gravel bed. Shallow test drilling would determine if additional water can be developed from sand and gravel beds adjacent to and recharged by the Huai Samran and Nam Kam and by rainfall. Existing dug wells could be deepened to afford water all the year round. A municipal water supply with filtration plant and distribution system is being planned by the Municipal and Public Works Department, using as a source of supply the Huai Samran.

\section{SURIN}

At Surin five dug wells supply water for the municipal area. Three of the wells (153-155), around the northeast perimeter of the village, yield low-chloride water from lateritic sandy clay. These wells range in depth from 6 to 23 feet and yield less than $6 \mathrm{gpm}$. Two others (wells 151 and 152), in the center of the village, yield water having a hardness of more than $400 \mathrm{ppm}$ and a chloride content of more than $300 \mathrm{ppm}$. These wells are probably contaminated by seepage of sewage in the area. In the dry season these wells go dry. Supplementing the supply from dug wells is water stored in the city klong during the rainy season. The Royal Department of Public Works is 
planning to develop a municipal water supply with a filtration plant using water from the Huai Saning, 3.6 kilometers southwest of the village.

\section{BURIRAM}

At Buriram, three wells (wells 156-158) ranging in depth from 8 to 10 feet are developed in lateritic clay. There are a few wells in the area that supply water low in chloride content and hardness. In the dry season these wells become dry.

\section{UBON TO KHORAT}

From Ubon to Khorat the railroad passes through Changwats Sisaket, Surin, and Buriram. Throughout this area a shortage of water has persistently been reported in the dry season. The soil is a lateritic clay, and shallow dug wells yield only small quantities of water barely adequate for domestic supplies during the rainy season and for a short period thereafter. Most of the water supplies in this area are obtained from canals, streams, and ponds. The shallow dug wells and the surface-water reservoirs are depleted during the long dry season and critical shortages of water exist throughout the area. Much additional water is needed for domestic and agricultural use. Three additional sources of water for potential development warrant investigation by means of exploratory wells: the weathered soil and bedrock, alluvial deposits of sand and gravel adjacent to permanent streams in areas favorable to recharge, and sandstone beds that would yield artesian water from depths as low as to 1,500 feet. Along the southern margin of the Khorat Plateau sandstone layers in the Triassic system may be an important potential source of water supply for municipalities, industries, and agriculture.

\section{SUMMARY}

As a part of this reconnaissance study a series of traverses were made across the Khorat Plateau to review the geology and correlate it with existing ground-water development. Characteristic wells were inventoried and water samples collected to determine the general quantity and quality of ground water available.

The Khorat Plateau is a large, shallow basin. Alternating beds of sandstone and shale dip, in general, from about $5^{\circ}$ to $10^{\circ}$ inward from the rim of the basin to its central part. Water entering the massive beds of sandstone in their outcrop area at the rim of the basin will migrate down dip and become confined under artesian pressure between the relatively impermeable shale layers. In the middle of the basin these beds may be at great depths and may yield highly mineralized water. However, around the outer margin of the plateau, 
wells from 100 to possibly 2,500 feet deep may be practical sources of supply.

Throughout the plateau, shallow dug and bored wells from 10 to as much as 75 feet in depth develop water under water-table conditions from the weathered soil and bedrock for domestic and limited village, school, and industrial use. In general, these wells yield from 5 to $10 \mathrm{gpm}$ each. Only a small number of wells have been constructed, and much additional water could be developed from such wells throughout the entire area. Wells of this type need to be properly constructed and maintained. Special care should be exercised in development of shallow wells in areas of concentrated population where shallow aquifers are subject to pollution. Studies that would aid development of this source of water include more detailed inventories of wells and sampling of water from existing wells for chemical analyses to delineate areas of ground water of poor quality.

Adjacent to streams and rivers and within the meanders of old streams, alluvial deposits of sand and gravel are excellent potential sources of ground water. Alluvial deposits are believed to be developed by dug and augered wells at Phimai, Khon Kaen, Nong Khai, Nakhon Phanom, Ubon, Yasothon, Mahasarakham, and Phibun. It is possible that wells producing more than $100 \mathrm{gpm}$ could be developed in some of these areas. Data from detailed inventories of wells should be supplemented with shallow test drilling or augering to outline the extent and thickness of these deposits. Pumping tests are needed to determine proper spacing and quantities of water available to wells. Care should be exercised in construction of these wells to guard against pollution.

This report is intended as an introduction to a series of ground-water reports by the Royal Department of Mines, Geological Survey of Thailand, in coordination with test-drilling and ground-water development programs being carried out by other Thai agencies. Future investigations should be directed at the systematic collection and reporting of the basic facts on source, occurrence, quality, and quantity of the ground-water supplies of the country. These studies are needed to outline areas where ground water of suitable quantity and quality can be developed for domestic, industrial, municipal, and irrigation supplies, to show annual fluctuations in water levels so that wells may be constructed deep enough to remain below the water table year-round, to aid proper well construction to guard against pollution, and to determine efficient spacing between wells and rates at which they can be pumped safely.

Coordinated with the ground-water studies and well-development projects, an educational program is needed to encourage the use of 
safe water supplies and good well construction and maintenance practices, and to encourage proper sanitary measures to protect all sources of potable ground water.

\section{SELECTED REFERENCES}

Army Map Service, 1944, Gazetteer to maps of Thailand: U. S. Department of Defense, Washington.

Bunnag, C. V., and Dhararaks, K. V., 1947, Climates of Siam: Royal Siamese Navy, Meteorolog. Dept., Scientific Articles No. 4.

Brown, G. F., Buravas, Saman, Charaljavanaphet, Jumchet, Jalichandra, Nitipat, Johnston, W. D., Jr., Sresthaputra, Vija, and Taylor, G. C., Jr., 1951, Geologic reconnaissance of the mineral deposits of Thailand: U. S. Geol. Survey Bull. 984.

Credner, Wilhelm, 1929, Problems of geomorphology in Siam: Jour. Siam Soc., National Hist. Sup., v. 8, no. 1, Bangkok.

- 1935, Siam, das land der Tai: Stuttgart, J. Engelhorns Nachf.

Dean, H. T., 1938, Endemic fluorosis and its relation to dental caries: U. S. Public Health Repts. v. 53, no. 33, p. 1443-1452.

Department of General Statistics, 1916-1944, Statistical Yearbook of the Kingdom of Siam, nos. 1-21.

Foster, E. E., 1948, Rainfall and runoff: New York, Macmillan Co.

Hallet, Halt, 1890, A thousand miles on an elephant: London, Blackwood \& Sons.

Hogbom, Bertil, 1914, Contributions to the geology and morphology of Siam: Upsala Univ., Geol. Inst., Bull., v. 12.

Hoyt, W. G., and others, 1936, Studies of relations of rainfall and runoff in the United States: U. S. Geol. Survey Water-Supply Paper 772.

Hydrology Section, 1953, Hydrological study of Huai Sam Ran, Huai Sam Ran Tank irrigation project, northeastern region 4, Sisaket, Aug. 30, 1953: Royal Irrig. Dept.

Jalichan, Nitipat, and Bunnag, Din, 1954, A report on geologic reconnaissance of the mineral resources in northeastern Thailand. Manuscript in files of the Thai Geol. Survey and Irrig. Dept.

Jalichan, Nitipat, 1954, Underground water-a possible solution to the water supply problem in northeastern Thailand. Manuscript in files of Thai Geol. Survey and Irrig. Dept.

Kaewphaithoon, Sangop, and Viraburus, Manas, 1953, Reconnaissance Geological Survey trip from Kabinburi to Pakthongehai and from Kabinburi to Chanthaburi, abstract. Manuscript in files of Thai Geol. Survey and Irrig. Dept.

Lee, Wallace, 1923, Reconnaissance geologic report of the Khorat Region. Manuscript in files of Thai Geol. Survey and Irrig. Dept.

_ 1927, Outline of the geology of Siam with reference to petroleum: Am. Assoc. Petroleum Geologists Bull. 11, no. 4, p. 411.

Meinzer, O. E., 1923a, The occurrence of ground water in the United States, with a discussion of principles: U. S. Geol. Survey Water-Supply Paper, 489.

1923b, Outline of ground-water hydrology, with definitions: U. S. Geol. Survey Water-Supply Paper 494. 
Meinzer, O. E., and others, 1942, Hydrology: Natl. Research Council, Physics of the Earth Ser., v. 9, New York, MeGraw-Hill Book Co., Inc. (Second printing by Dover Publications, Inc., New York, 1949).

Meteorological Department, 1937-41, Annual meteorological reports, v. 1-5.

Pendleton, L. D., Provisional map of the soils and surface rocks of the Kingdom of Thailand.

Public Health Service Drinking Water Standards, 1946: U. S. Public Health Repts. 2697, Reprint.

Central Statistical Office, Statistical Year Book of Thailand, National Economic Council, 1952.

Wood, W. A. R., 1933, A history of Siam, 98 p., Bangkok. 


\section{TABLE 2.-Records of wells}

[Type of well: B, bored; D, dug; Dr, drilled. Method of lift: Cyl, deep-well cylinder; B, bucket. Use of 6-inch-diameter commercial

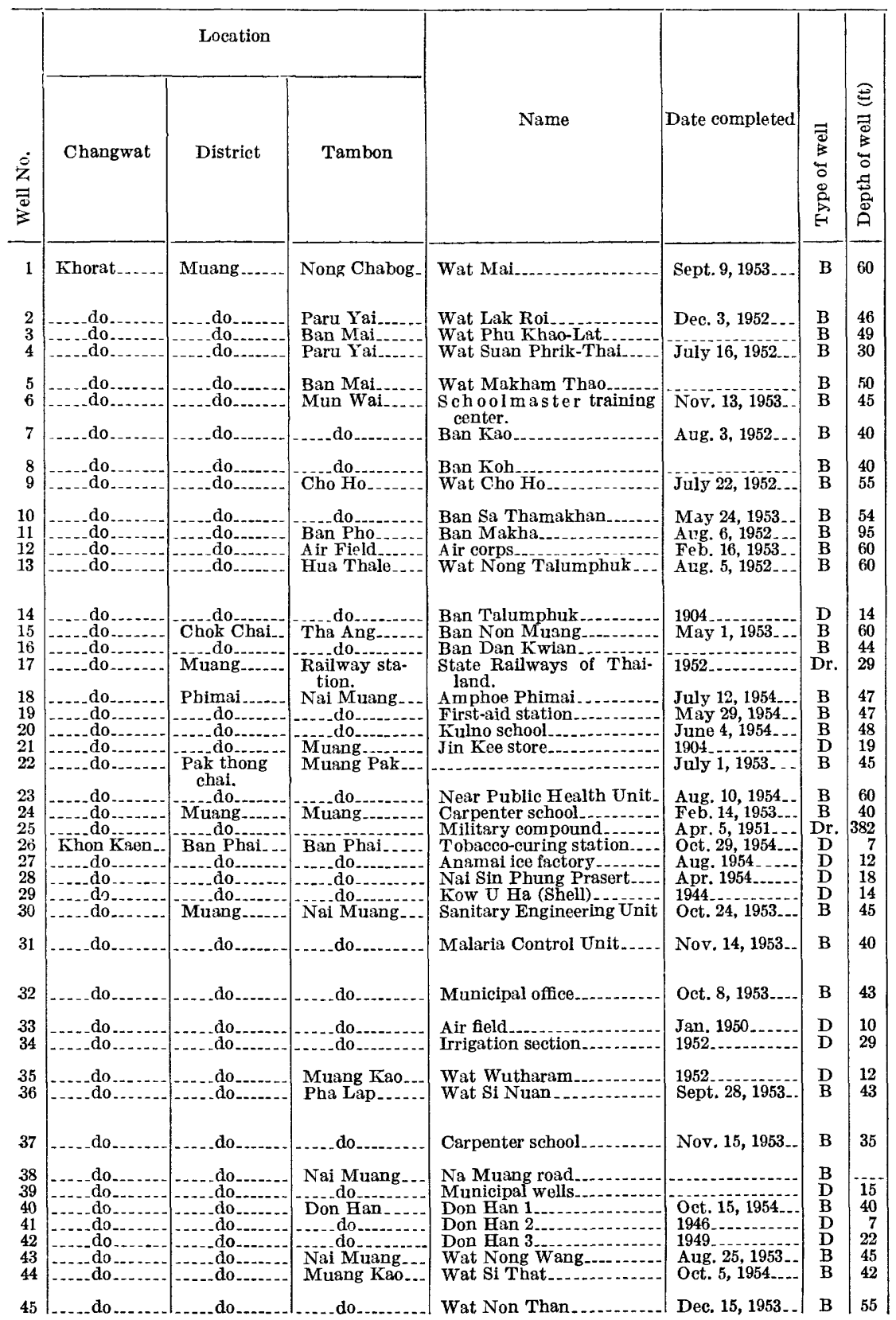




\section{in the Khorat Plateau}

water: D, domestic; H, hospital; I, industry; PS, public supply; W, washing. Note: screens used are well screens made of stainless steel]

\begin{tabular}{|c|c|c|c|c|c|c|c|c|c|c|c|c|c|c|}
\hline \multirow[b]{2}{*}{ 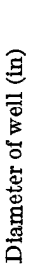 } & \multirow{2}{*}{ 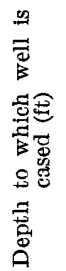 } & \multirow[b]{2}{*}{ 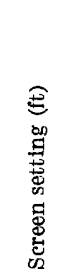 } & \multicolumn{3}{|c|}{$\begin{array}{l}\text { Principal water- } \\
\text { bearing bed }\end{array}$} & \multicolumn{2}{|r|}{ Water level } & \multirow[b]{2}{*}{ 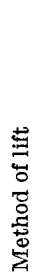 } & \multirow[b]{2}{*}{ 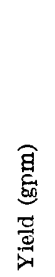 } & \multirow[b]{2}{*}{ 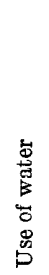 } & \multicolumn{4}{|c|}{ Quality of water } \\
\hline & & & 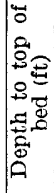 & 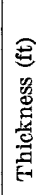 & 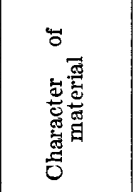 & 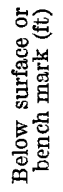 & 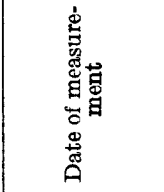 & & & & 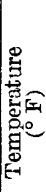 & 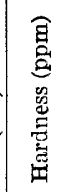 & 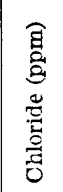 & 装 \\
\hline 6 & 45 & $45-60$ & 45 & 15 & $\begin{array}{l}\text { Fine- } \\
\text { grained } \\
\text { sand. }\end{array}$ & & Sept. 9, & $\mathrm{Cyl}$ & 6 & W & 81 & 732 & 2,800 & $7.0-7.5$ \\
\hline 6 & 35 & $35-40$ & 25 & 21 & Sand. & 10 & Dec. 18,1952 & $\mathrm{Cyl}$ & & W & & & & \\
\hline $\begin{array}{l}6 \\
6\end{array}$ & 39 & & $\begin{array}{l}30 \\
25\end{array}$ & $\begin{array}{r}19 \\
5\end{array}$ & $\begin{array}{c}\text { Sand-.. } \\
\text { stone }\end{array}$ & 39. 8 & $\begin{array}{l}\text { Sept. } 29, \\
\text { July } 16,\end{array}$ & $\begin{array}{l}\mathrm{Cyl} \\
\mathrm{Cyl}\end{array}$ & 6 & $\begin{array}{l}\text { PS } \\
\text { PS }\end{array}$ & 82 & 552 & 1,500 & $7.5-8.0$ \\
\hline $\begin{array}{l}6 \\
6\end{array}$ & & & 30 & 15 & $\begin{array}{l}\text { Sand - } \\
\text { Sand and }\end{array}$ & (1) & $\ldots$..... do & $\begin{array}{l}\text { Cyl } \\
\text { Cyl }\end{array}$ & $13_{4}$ & WV & 82 & 280 & 272 & 7. 5-8.0 \\
\hline 6 & 30 & $30-40$ & 35 & 20 & Sand & & Aug. 1 , & Cyl & & W & & & & \\
\hline 6 & & $30-40$ & 30 & 10 & San & 30 & Oct. 29 , & $\mathrm{Cyl}$ & & $\mathrm{W}$ & & & & \\
\hline 6 & 45 & $45-55$ & 43 & 12 & $\begin{array}{l}\text { Sandy } \\
\text { clay. }\end{array}$ & 45 & & Cyl & & W & -- & $\cdots$ & & - \\
\hline $\begin{array}{l}6 \\
6\end{array}$ & 40 & & $\begin{array}{l}40 \\
50\end{array}$ & $\begin{array}{l}14 \\
45\end{array}$ & ..do do.. & $\begin{array}{l}40 \\
20\end{array}$ & & $\begin{array}{l}\mathrm{Cyl} \\
\mathrm{Cyl}\end{array}$ & $\begin{array}{l}3 \\
4\end{array}$ & $\begin{array}{l}\text { W } \\
\text { W }\end{array}$ & $\begin{array}{l}85 \\
85\end{array}$ & $\begin{array}{r}512 \\
1,170\end{array}$ & $\begin{array}{l}2,310 \\
1.440\end{array}$ & $\begin{array}{r}7.5-8.0 \\
7.0\end{array}$ \\
\hline 6 & 48 & $48-58$ & 40 & 10 & Clay & 35 & do & $\mathrm{Cyl}$ & 6 & $W$ & 85 & 272 & 386 & 7. $5-8.0$ \\
\hline 6 & 45 & $45-60$ & $\cdots$ & $\ldots$ & $\begin{array}{l}\text { Fine- } \\
\text { grained } \\
\text { sand. }\end{array}$ & 18 & do & Cyl & 6 & $\ddot{W}$ & 82 & 80 & 16 & $6.5-7.0$ \\
\hline $\begin{array}{r}47 \\
6\end{array}$ & $\begin{array}{l}14 \\
45\end{array}$ & $45-60$ & -- & $-\overline{1}$ & White sand & $\begin{array}{r}4 \\
20\end{array}$ & $\ldots d$ & $\begin{array}{c}\mathrm{B} \\
\mathrm{Cyl}\end{array}$ & 6 & $\begin{array}{l}\text { PS } \\
\text { PS }\end{array}$ & $\begin{array}{l}81 \\
81\end{array}$ & $\begin{array}{r}16 \\
148\end{array}$ & $\begin{array}{l}19 \\
25\end{array}$ & $\begin{array}{r}6.5-7.0 \\
7.0\end{array}$ \\
\hline $\begin{array}{l}6 \\
4\end{array}$ & $\begin{array}{l}24 \\
33\end{array}$ & & 34 & 10 & Sand. & & $\begin{array}{l}\text { Oct. } 30 \text {, } \\
\text { do }\end{array}$ & $\mathrm{Cyl}$ & 3 & W & $\begin{array}{c}84 \\
-\ldots\end{array}$ & $\begin{array}{r}1,980 \\
388\end{array}$ & $\begin{array}{r}96 \\
264\end{array}$ & $\begin{array}{r}7.5 \\
7.5-8.0\end{array}$ \\
\hline 6 & 37 & 17 & 35 & 12 & $\mathrm{Sa}$ & 30 & & $\mathrm{Eyl}$ & 6 & W & 83 & 22 & 180 & \\
\hline 6 & 37 & & 33 & 14 & $\ldots d$ & 29 & & CI & 6 & PS & 2 & 47 & 211 & 7.5 \\
\hline $\begin{array}{r}6 \\
44\end{array}$ & $\begin{array}{l}38 \\
19\end{array}$ & $38-48$ & 33 & 15 & -...do.. & 25 & $-\mathrm{dc}_{\mathrm{d}}$ & Cyl & 6 & PS & 83 & 436 & 220 & $7.5-8.0$ \\
\hline 6 & 30 & $30-42$ & $\cdots$ & $\cdots$ & n. & $\begin{array}{r}4 \\
35.6\end{array}$ & . & Cyl & 6 & $\mathbf{w}$ & 82 & 204 & 66 & $7.0-7.5$ \\
\hline 6 & 45 & & $\ldots$ & & & & do & Cyl & 12 & PS & 83 & 1,240 & 955 & $7.0-7.5$ \\
\hline $\begin{array}{l}6 \\
6\end{array}$ & 26 & & 65 & 33 & & (2) & & Cy! & & $\ddot{W}$ & $\cdots$ & - & $\cdots$ & $\cdots$ \\
\hline 59 & & & 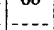 & & & & . 2. & $\mathrm{~B}$ & & PS & 82 & 7 & 9 & $6.5-7.0$ \\
\hline 118 & 12 & & $\cdots$ & $\ldots$ & Sand & 5 & do do & $\mathrm{Cyl}$ & & I & 80 & 264 & 480 & $7.0-7.5$ \\
\hline 39 & 16 & & -..- & $-\ldots$ & $\mid-\ldots+\cdots$, & 12 & -..do & B & $\cdots$ & $\mathbf{W}$ & & & 915 & $7.5-8.0$ \\
\hline $\begin{array}{r}39 \\
6\end{array}$ & $\begin{array}{l}14 \\
35\end{array}$ & & 25 & 20 & Sand & $\begin{array}{r}3 \\
20\end{array}$ & Nov. 3,1954 & $\begin{array}{c}\text { B } \\
\text { Cyl }\end{array}$ & 15 & $\begin{array}{l}\mathrm{W} \\
\mathrm{W}\end{array}$ & $\begin{array}{l}79 \\
85\end{array}$ & $\begin{array}{l}300 \\
900\end{array}$ & $\begin{array}{r}512 \\
2,270\end{array}$ & $\begin{array}{r}6.5 \\
7.5-8.0\end{array}$ \\
\hline 6 & 32 & & 30 & 10 & $\begin{array}{l}\text { Sand, clay, } \\
\text { and }\end{array}$ & 12 & do & Cyl & 3 & $\mathbf{W}$ & 84 & 504 & 410 & 7.5 \\
\hline 6 & 35 & & 25 & 15 & $\begin{array}{l}\text { gravel. } \\
\text { Sand and }\end{array}$ & 20 & ............. & Cyl & 6 & $\mathrm{~W}$ & 83 & $890^{\circ}$ & 708 & $7.0-7.5$ \\
\hline 71 & 10 & & $\ldots$ & $\ldots$ & & 5 & $\ldots d$ & B & $\cdots$ & PS & 84 & 16 & 10 & 6. \\
\hline 5 & 29 & & $\cdots$ & $\cdots$ & $\begin{array}{c}\text { Sand } \\
\text { gra }\end{array}$ & 20 & & B & $=-1$ & PS & 81 & 132 & 78 & -7.5 \\
\hline 47 & 12 & & & & clay & 4 & $\ldots$ & $B$ & & PS & 84 & 2 & & 6.5 \\
\hline 6 & 40 & & 30 & 13 & $\begin{array}{l}\text { Pebbles, } \\
\text { sand, and } \\
\text { clay, }\end{array}$ & 15 & so & Cyl & 4 & W & 84 & $76 \overline{8}$ & 1,060 & 7.0-7.5 \\
\hline 6 & 32 & & 20 & 15 & $\begin{array}{l}\text { Clay and } \\
\text { gravel. }\end{array}$ & 8 & do & Cyl & 4 & $W$ & 85 & 228 & 153 & $7.0-7.5$ \\
\hline $\begin{array}{r}6 \\
39\end{array}$ & & & & $\cdots$ & 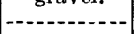 & & $\ldots d$ & $\mathrm{Cyl}$ & 6 & W & 85 & 812 & 4,230 & 7. 5-8. 0 \\
\hline $\begin{array}{r}39 \\
6\end{array}$ & 15 & & & & & 13 & ..do do & B & 6 & PS & 84 & & 10 & 6.5 \\
\hline $110^{\circ}$ & on & & -- & 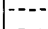 & $\ldots$ & $\begin{array}{l}5 \\
4\end{array}$ & $\begin{array}{l}\text {...do do } \\
\ldots \text { do }\end{array}$ & Oyl & 6 & PS & $\begin{array}{l}83 \\
83\end{array}$ & $\begin{array}{r}1,580 \\
8\end{array}$ & 2,190 & 7.5 \\
\hline 43 & & & & & & 18 & & $\mathbf{D}$ & & PS & 79 & 136 & 163 & 6.5 \\
\hline 6 & 40 & & $\ldots$ & - & & & -do & $\mathrm{Cyl}$ & & PS & & & & \\
\hline 6 & 20 & & & $\ldots$ & $\begin{array}{l}\text { Clay and } \\
\text { sand. }\end{array}$ & 3 & & Cyl & & PS & & $\ldots$ & $-\ldots$. & \\
\hline 6 & 50 & & & & do. & & & $\mathrm{Cyl}$ & & PS & & & & \\
\hline
\end{tabular}

1 Flows.

2 At land surface. 
TABLE 2.-Records of wells

\begin{tabular}{|c|c|c|c|c|c|c|c|}
\hline \multirow[b]{2}{*}{$\begin{array}{l}\dot{0} \\
z \\
= \\
z\end{array}$} & \multicolumn{3}{|c|}{ Location } & \multirow[b]{2}{*}{ Name } & \multirow[b]{2}{*}{ Date completed } & \multirow[b]{2}{*}{ 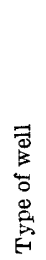 } & \multirow[b]{2}{*}{ 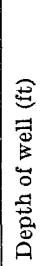 } \\
\hline & Changwat & District & Tambon & & & & \\
\hline 46 & Khon Kaen - & Muang & Ban Tun & Public Health Unit. & Feb. & B & 28 \\
\hline 47 & - & -...do- & ..... do & Ban Tum public well. & 1924 & $\underset{\mathrm{B}}{\mathrm{D}}$ & 26 \\
\hline $\begin{array}{l}48 \\
49\end{array}$ & 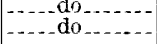 & Chumphae. & Non Han & $\begin{array}{l}\text { Military compound } \\
\text { Nai Tum Chaiyanand... }\end{array}$ & $\begin{array}{l}1954 .-1 \\
\text { Nov. } 2,1954\end{array}$ & $\stackrel{\mathrm{B}}{\mathrm{D}}$ & -5 \\
\hline 50 & - do & Muang. & Samran & Nai Ong Lee. & July 4 & $\mathrm{D}$ & 16 \\
\hline 51 & Udon Thani. & _. & Ban Tai & Wat Pho Chayaram & 1946 & $\mathrm{D}$ & 17 \\
\hline 52 & $\ldots . . . d n \ldots$ & .....do_ & Mak Kha & Surakan road....... & 1953 & B & \\
\hline 53 & $-\ldots-2 d o$ & . . do & $-\ldots d o_{-}$ & Intestinal Parasite Con- & Nov. 19 & $\bar{B}$ & 35 \\
\hline 54 & -...do. & do & do & Nat Chot Khotnarong.... & 1952 & $\mathrm{D}$ & 22 \\
\hline 55 & {$\left[\begin{array}{ll}2 \\
-\ldots\end{array}\right.$} & -...do_ & do & Udon Thani kindergarten & 1953 & B & \\
\hline 56 & 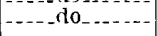 & do & do & Provincial health officer's & 1952 & $\mathrm{~B}$ & 25 \\
\hline 57 & ..... do & .....do_ & -_do_. & $\begin{array}{l}\text { house. } \\
\text { Girl's dormit }\end{array}$ & & B & \\
\hline 58 & - do & - do & Ban Non & Regional governor's house & & B & \\
\hline $\begin{array}{l}59 \\
60\end{array}$ & -..ddo_- & -...do do & Mak Khaeng. & $\begin{array}{l}\text { Sai Swai farm } \\
\text { Post office }\end{array}$ & July $17,1953 \ldots$ & $\stackrel{\mathrm{B}}{\mathrm{B}}$ & $\begin{array}{l}30 \\
18\end{array}$ \\
\hline 61 & -..._do & do & $\ldots$ & Provincial health of & Aug. 2h, 1954_. & B & 80 \\
\hline fi2 & .... do & d & & Polic & & $\mathrm{B}$ & 25 \\
\hline 63 & $\ldots d$ & $\ldots d$ & $\ldots d$ & Sanitary engineering unit & Oct. 27,1 & B & 50 \\
\hline fit & .....do do & ..... do & .... do & Irrigation section. & 1954 & $\mathrm{~B}$ & 20 \\
\hline 65 &..--1 & $-\ldots d o$ & Ban Ta & Kum Kling railway station & Oct. 1 & $\mathrm{~B}$ & 50 \\
\hline 66 & 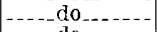 & $\ldots-. . d o$ & -...do. & Nai Naun Chitaphan.... & 1944 & D & 15 \\
\hline 67 & -....de & -...-do & - & Barracks & Dec. 1 & B & 28 \\
\hline 68 & .....do & ...-.do & Nong Bus & Wat Yotha Nimit.. & 1951. & $\mathrm{D}$ & 12 \\
\hline 69 & .....do & -...do do & _...do do & Tank corps. & Jan. 19 & B & 40 \\
\hline 70 & -.... dc & $-\ldots-. d o$ & $-\ldots$. & Nong Khon Kwang & Oct. 1954 & B & 39 \\
\hline 71 & -...do & $\ldots$.... do & $\ldots d o$ & Near Nong Kham railway & Apr. 1953 & B & 50 \\
\hline 72 & $\ldots$. & $\ldots d$ & $d$ & Land corps branch & Oct & $\mathrm{B}$ & 70 \\
\hline 73 & $-\infty$ d & - d & Chie & Wat Nong Ku & & B & 11 \\
\hline 74 & $\ldots d$ & d & Ban Khao.. & Nai Trakun Khongburan & 1952 . & $\mathrm{D}$ & 11 \\
\hline 75 & Nong Kl & _...do. & Ta Khai .. & Yang Kham school.. & 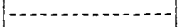 & $\mathrm{D}$ & 15 \\
\hline 76 & .....do_ & - do & Mee Chai & Nai Manit Tee Akson & 1944 & D & 12 \\
\hline 77 &..$--- d 0$ & & Nai Muar & Wat Pho Si. & & D & 26 \\
\hline 78 & .....do & .....do_ & .....do. & Wat Khun Muang. & 1940 & $\mathrm{D}$ & 35 \\
\hline 79 & $-{ }_{-} \mathrm{d} \mathrm{d}_{2}$ & - nd & & Pro & & $\mathrm{D}$ & 33 \\
\hline 80 & $\begin{array}{l}\text { Sakon Nak- } \\
\text { hon. }\end{array}$ & $-2 \mathrm{do}$ & $\begin{array}{l}\text { That Cherg- } \\
\text { chum. }\end{array}$ & Wat Sisaket & & $\mathrm{D}$ & 24 \\
\hline 81 & $-\ldots d$ & $\ldots$ do. & & Nai Kerng Phromsakha & 1954 & $\mathrm{D}$ & 17 \\
\hline 82 & & & -... & Near air field. & & $\mathrm{D}$ & 10 \\
\hline 83 & ......do & .... do & -.... do & Nai Darug Wongsa phan. & & $\mathrm{D}$ & 15 \\
\hline 84 & - ... do do & -....do & -....d & Nane Kongsi Clettha & 1944 & D & 13 \\
\hline 85 & & & & Wat Sphan Kham.. & 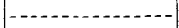 & $\Gamma$ & 23 \\
\hline 96 & $\ldots \mathrm{do}$ & -....do. & $-2 d$ & Wat Phra That. & & D & 11 \\
\hline 87 & $-\vec{T}=-\mathrm{do}_{-.}$ & - & $\therefore$ ado & Nang Pam Wong Kalasin & & $\mathrm{D}$ & 11 \\
\hline 88 & $\begin{array}{l}\text { Udon } \\
\text { Thani. }\end{array}$ & $\begin{array}{l}\text { Nong } \\
\text { Harn. }\end{array}$ & Nong Har & Nai Phibun & 1951 & $\mathbf{D}$ & 18 \\
\hline 89 & ........ do & Ldo & $-1-1$ & Bo Sawnev spring & & D & 9 \\
\hline 90 & $\begin{array}{l}\text { Sakon } \\
\text { Nakhon. }\end{array}$ & $\begin{array}{l}\text { Swang } \\
\text { Daen } \\
\text { Din. }\end{array}$ & $\begin{array}{l}\text { Swang Daen } \\
\text { Din. }\end{array}$ & Wat Pho Si & & $\overline{\mathbf{D}}$ & 15 \\
\hline & -.--do do & -.do- & ......do. & Amphoe Swang Daen Din & & $\mathrm{D}$ & $\begin{array}{l}23 \\
18\end{array}$ \\
\hline $\begin{array}{l}92 \\
93\end{array}$ & $\ldots \mathrm{do}$ & ....do_ & do. & Wat Swang Phumidon & $1946 \ldots$ & D & 18 \\
\hline 93 & -....do do & Phannani- & Phannani- & Nai Dam Saen. & 1949 & D & 11 \\
\hline 94 & ....do... & -...do & $\pi$ & Nai Wiwat Intharaphanit & Feb. 1953.... & $\mathrm{D}$ & 17 \\
\hline
\end{tabular}


in the Khorat Plateau-Continued

\begin{tabular}{|c|c|c|c|c|c|c|c|c|c|c|c|c|c|c|}
\hline \multirow[b]{2}{*}{ 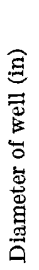 } & \multirow{2}{*}{ 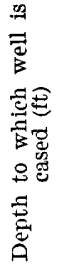 } & \multirow[b]{2}{*}{ 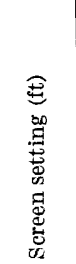 } & \multicolumn{3}{|c|}{$\begin{array}{l}\text { Principal water- } \\
\text { bearing bed }\end{array}$} & \multicolumn{2}{|c|}{ Water level } & \multirow[b]{2}{*}{ 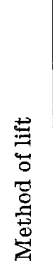 } & \multirow[b]{2}{*}{ 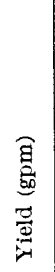 } & \multirow[b]{2}{*}{ 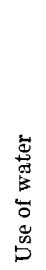 } & \multicolumn{4}{|c|}{ Quality of water } \\
\hline & & & 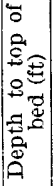 & 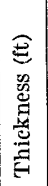 & 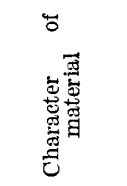 & 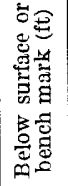 & 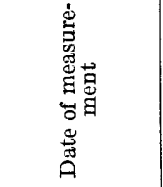 & & & & 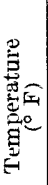 & 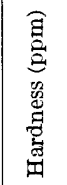 & 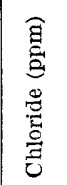 & 푬. \\
\hline 6 & & & & & Sand. & & Nov. 3,1954 & $\mathrm{Cy}$ & 8 & $W$ & 85 & 2,640 & 4,480 & $7.5-8.0$ \\
\hline 79 & 26 & $-\cdots$ & $-\cdots$ & & & 8 & -... do do.......... & $\stackrel{\text { B }}{\mathrm{Cy}}$ & & PS & $\begin{array}{l}83 \\
84\end{array}$ & $\begin{array}{r}13 \\
388\end{array}$ & 16 & $\begin{array}{r}6.5 \\
6.7\end{array}$ \\
\hline $\begin{array}{c}6 \\
---\end{array}$ & None & & $\cdots$ & -- & $\begin{array}{l}\text { Sandy } \\
\text { clay }\end{array}$ & 3 & Nov. 4.1954 & B & 7 & $\begin{array}{l}\text { W } \\
\text { PS }\end{array}$ & $\begin{array}{l}84 \\
78\end{array}$ & $\begin{array}{r}388 \\
16\end{array}$ & $\begin{array}{r}782 \\
4\end{array}$ & $\begin{array}{r}6.5-7.0 \\
6.5\end{array}$ \\
\hline 43 & $\begin{array}{r}15 \\
T-n e\end{array}$ & & 5 & 10 & & 7 & Nov, 5, 1954 & $\underset{\mathrm{B}}{\mathrm{B}}$ & $\cdots--$ & $\mathrm{PS}$ & $\begin{array}{l}81 \\
80\end{array}$ & 11 & $\begin{array}{r}104 \\
16\end{array}$ & 7.5 \\
\hline--- & Nome & & & $\begin{array}{c}10 \\
---\end{array}$ & Laterd & $y$ & 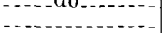 & Cyl & 6 & $W$ & 82 & 2,440 & 240 & $\begin{array}{l}0.0 \\
6.0\end{array}$ \\
\hline 6 & 18 & $-\cdots$ & --- & 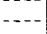 & & $-\ldots$ & & Cyl & 6 & W & 82 & 418 & 108 & 6.0 \\
\hline 55 & 11 & - & ---- & --- & White & 6 & - & $\mathrm{B}$ & & $\mathrm{D}$ & 79 & 59 & 11 & 6.0 \\
\hline & & & & & |-. & & & Cyl & 6 & W & 83 & 6., 950 & 585 & 7.0 \\
\hline 6 & 15 & & & - & & & & $\mathrm{Cyl}$ & 4 & $\mathrm{~W}^{*}$ & 84 & 620 & 32 & 6.5 \\
\hline$=-$ & & & & $=$ & & & & Cyl & 4 & W & 82 & 2,450 & 168 & 6.0 \\
\hline & & & & & & & & Cyl & 6 & W & 81 & 3,380 & 129 & 6.5 \\
\hline 6 & 25 & $25-30$ & $\ldots$ & $\ldots$ & White clay & $\ldots$ & Nov. 6,1954 & Cyl & 8 & PS & 84 & 269 & 32 & 7.0 \\
\hline 6 & 5 & $5-15$ & & & Fine- & $-\cdots$ & $\ldots d a \ldots$ & Cyl & 6 & $\mathrm{PS}$ & 82 & 67 & 35 & 6.5 \\
\hline 6 & 20 & $20-25$ & $\ldots$ & $-\ldots$ & $\begin{array}{c}\text { Sand. } \\
-\end{array}$ & -. & $\ldots d \theta_{-.}$ & $\mathrm{Cyl}$ & 8 & W & 84 & 283 & 52 & 6.0 \\
\hline 6 & 12 & $12-25$ & $\ldots$ & - & Sandy clay & $\ldots$ & . do...... & Cyl & 6 & W & 84 & 25 & 11 & 6.0 \\
\hline 6 & 26 & $26-31$ & - & --- & . do & - & do & Cyl & 8 & W & 84 & 1,570 & 60 & 6.0 \\
\hline 6 & 15 & $15-20$ & $-\ldots$ & $-\ldots$ & do & $-\ldots$ & - du & Cy1 & 8 & W & 85 & 1,860 & 96 & 6.0 \\
\hline 6 & 38 & $38-43$ & $\ldots$ & $\ldots$ & - & & $\ldots d t$ & Cyl & 6 & W & 83 & 150 & 212 & 7.0 \\
\hline & 15 & & $\mid \begin{array}{l}-1- \\
--.-\end{array}$ & 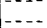 & 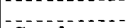 & 4 & ...do. & B & & PS & 79 & 140 & 40 & 6.5 \\
\hline 6 & 20 & $20-25$ & $-\ldots$ & $\ldots$ & Sand & & -...do do & Cyl & 6 & $\mathrm{~W}$ & 84 & 3,600 & 720 & 7.0 \\
\hline-- & None & & $\ldots$ & $\ldots$ & - & 9 & -..._do & $\mathrm{B}$ & & PS & 79 & 13 & 24 & 7.0 \\
\hline 6 & 30 & $30-40$ & $-\ldots$ & $\ldots$ & 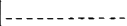 & $\ldots$ & _. do & Cyl & 6 & $\mathrm{D}$ & 82 & 19 & 60 & 7.0 \\
\hline 6 & 30 & $30-35$ & $-\ldots$ & $\ldots$ & -5 & $\ldots$ & ..... 10. & Cyl & 6 & PS & 86 & 52 & 144 & 7.0 \\
\hline 6 & 40 & $40-50$ & 1 & $\ldots$ & ret & $\ldots$ & -...do... & Cyl & 5 & W & 84 & 9,440 & 580 & 7.0 \\
\hline 6 & 25 & $25-45$ & $\ldots$ &.- & & $\ldots$ & . do. & Cyl & 6 & $W$ & 83 & 3,440 & 304 & 7.0 \\
\hline 6 & & 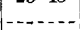 & & & & & & $\mathrm{Cyl}$ & & PS & & & & \\
\hline 39 & 11 & 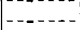 & & - & & 4 & & $\mathrm{~B}$ & & PS & 80 & 16 & 18 & 7.0 \\
\hline 47 & 15 & --n- & & & $\begin{array}{l}\text { Shallow } \\
\text { stund. }\end{array}$ & 6 & $-2--$ & B & $\ldots$ & $\mathrm{W}$ & 81 & 20 & 30 & 7.0 \\
\hline 79 & 5 & $\ldots$ & 5 & 7 & Laterite... & 5 & & B & & PS & 79 & 32 & 44 & 7.0 \\
\hline 79 & 25 & $\ldots \ldots$ & ---- & $\ldots$ & $\begin{array}{l}\text { Shallow } \\
\text { Sand? }\end{array}$ & 8 & & B & - & PS & 80 & 240 & 32 & 7.0 \\
\hline 63 & 33 & $-\ldots$ & ---- & .. & - & 22 & & B & & $\mathrm{PS}$ & 81 & 335 & 185 & 7.0 \\
\hline 47 & 33 & $-\ldots \ldots$ & $\ldots$ & $-\ldots$ & $\ldots$ do & 7 & & $\mathrm{Cyl}$ & 12 & $\mathrm{H}$ & 81 & 104 & 26 & 7. 0 \\
\hline 71 & 24 & 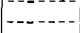 & --- & $-\cdots$ & ....do....... & 7 & & $B$ & $\ldots$ & W & 81 & 120 & 202 & 7.0 \\
\hline 47 & 16 &.- & & $\ldots$ & ...._do.. & 9 & & B & & PS & 79 & 372 & 225 & 7.0 \\
\hline 47 & & $\ldots \ldots$ & $\ldots$ & $-\cdots$ & do & 4 & & B & & $\mathrm{PS}$ & 78 & 284 & 121 & 7.0 \\
\hline 43 & 15 & -.... & $\ldots$ & $\ldots$ & .....do & 6 & & B & & W & 79 & 48 & 706 & 7.0 \\
\hline 43 & 13 & 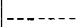 & $\ldots$ & $\ldots$ & $\ldots$ do $\ldots$ & 6 & $\ldots$ & B & & W & 79 & 256 & 246 & 7.0 \\
\hline 51 & 23 & -....... & $\ldots$ & $\ldots$ & $\ldots$ do $\ldots$ & 7 & - & B & $-\cdots$ & W & 79 & 432 & 371 & 7. \\
\hline 71 & 11 & 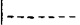 & $\ldots$ & $\ldots$ & $\ldots \mathrm{do}_{-}$ & 4 & - & B & & PS & 80 & 344 & 145 & 7. 0 \\
\hline 31 & 11 & $-\ldots$ & $\ldots$ & $\ldots$ & $\ldots \mathrm{d} 0 \ldots$ & 5 & $\ldots$ & B & & $W$ & 79 & 256 & 167 & 6.5 \\
\hline 51 & 18 & $\ldots$ & $\ldots$ & $\ldots$ & .... do... & 5 & - & $\mathrm{B}$ & & W & 78 & 416 & 333 & 8.0 \\
\hline & 9 & $0-2-0$ & $|---|$ & & - _ _ do & (3) & & $\mathrm{B}$ & & PS & 78 & 80 & 82 & 7.0 \\
\hline 59 & 15 & $\ldots$ & $-\ldots$ & $\ldots$ & $\ldots d n \ldots$ & 5 & |-n. & $\mathrm{B}$ & $-\cdots$ & W & 78 & 8 & 15 & 7.0 \\
\hline 47 & 23 & $\ldots$ & $-\ldots$ & $\ldots$ & .... do & 20 & . & $\mathrm{B}$ & & W & 81 & 244 & 374 & 8.0 \\
\hline 49 & 18 & -..... & $-\ldots$ & $\ldots$ & $\ldots d \mathrm{~d}_{-}$ & 6 & & B & & W & 80 & 8 & 6 & 6.5 \\
\hline 39 & 11 & - &.--- & $-\ldots$ & ....do. & 6 & 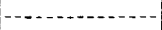 & B & -... & PS & 79 & 320 & 19 & 5.2 \\
\hline 47 & 17 & & & & . do & 5 & & B & & $W$ & 81 & 52 & 11 & 5.4 \\
\hline
\end{tabular}

${ }^{3}$ Flows-Spring. 
TABLE 2.-Records of wells

\begin{tabular}{|c|c|c|c|c|c|c|c|}
\hline \multirow[b]{2}{*}{ 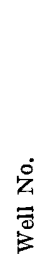 } & \multicolumn{3}{|c|}{ Location } & \multirow[b]{2}{*}{ Name } & \multirow[b]{2}{*}{ Date completed } & \multirow[b]{2}{*}{ 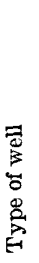 } & \multirow[b]{2}{*}{ 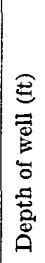 } \\
\hline & Changwat & District & Tambon & & & & \\
\hline 95 & Sakon & Muang. & Kusuman & Nai Mong Kang. & 1944 & $\mathbf{D}$ & 13 \\
\hline 96 & Nakon & ...... do. & Nai Sai. & Wat Phon Kha. & 1934 & $\mathrm{D}$ & 23 \\
\hline 97 & -- do.. & That & Saen Phan & Ban Man Yon.. & 1947 & $\mathrm{D}$ & 36 \\
\hline 98 & ......do & Pnanom. & That & Wat That Phanom & About 950 & $\mathrm{D}$ & $3\rceil$ \\
\hline $\begin{array}{r}99 \\
100\end{array}$ & do. & Muang.- & Nong Buk & Municipal public well. & $1944-$ & $\mathrm{D}$ & 31 \\
\hline 101 & -...do do & 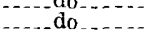 & Nai doutig & Nai Suan Phromprakai... & 1948 & $\mathrm{D}$ & $\begin{array}{l}+9 \\
28\end{array}$ \\
\hline 102 & -...do & That Pha- & That Phanom & Wat Phra That Phanom & June 24,1954 & $\mathrm{D}$ & $-\cdots$ \\
\hline 103 & -..... do. & Hodo. & .....do. & Nai Amphoe's hous & 1950 & $\mathrm{D}$ & 33 \\
\hline 104 & ..do. & Mukdahan.. & Mnkdahan & Near post office. & & $\mathrm{D}$ & 33 \\
\hline 105 & Ubon ... & Amnat & Amnat & Public health unit & 1939 & $\mathrm{D}$ & 20 \\
\hline 106 & do & $\begin{array}{l}\text { Muang } \\
\text { Samsib. }\end{array}$ & Muang & Amphoe Muang Samsib. & & $\mathrm{D}$ & 28 \\
\hline $\begin{array}{l}107 \\
108\end{array}$ & .... do do & Muang... & 20 & $\begin{array}{l}\text { Public health center } \\
\text { Provincial kindergarten... }\end{array}$ & $\begin{array}{l}\text { Oct. } 1954 \\
\text { June } 1954\end{array}$ & $\stackrel{B}{B}$ & $\begin{array}{r}100 \\
50\end{array}$ \\
\hline 109 & do & do. & & Benchama Maharat & Oet. 19 & B & 75 \\
\hline $\begin{array}{l}110 \\
111\end{array}$ & $-d$ & ....do & Pathum & Nai Fong Sithitham & 1944 & $\mathrm{D}$ & 32 \\
\hline $\begin{array}{l}111 \\
112\end{array}$ & & do & .....do.. & $\begin{array}{l}\text { Ubon Mission hospit } \\
\text { Municipal well }\end{array}$ & - & $\begin{array}{l}\mathrm{D} \\
\mathrm{D}\end{array}$ & $\begin{array}{l}17 \\
22\end{array}$ \\
\hline 113 & & ...... do & Pathum. & Wat Swang.... & $1934 \ldots \ldots$ & $\mathrm{D}$ & 21 \\
\hline 114 & do & Warin- & Tat... & Highways office... & June $28,1951 \ldots$ & $\mathrm{D}$ & 37 \\
\hline 115 & do & do do & & Military compound.. & Aug. & $B$ & 50 \\
\hline 116 & do & Muang.. & & Asylum Phra Si Mahapho. & Sept. 15,1954 & $\underset{B}{B}$ & $\begin{array}{l}50 \\
50\end{array}$ \\
\hline 118 & ..... do & -.... do & Pathum. & $\begin{array}{l}\text { Gas storage } \\
\text { Pathum Ubon school. }\end{array}$ & June $30,1954 \ldots$ & $\mathrm{B}$ & 55 \\
\hline 119 & - & $\ldots$ do & & Dr. Surin's store. & $1952 \ldots .$. & $\mathrm{D}$ & 43 \\
\hline 120 & $-d$ & .....do_ & & Slaughter house - & & $\mathrm{D}$ & 33 \\
\hline $\begin{array}{l}121 \\
122\end{array}$ & do & Det Udom. & Na Swang & Government office & 1924 & $\stackrel{D}{D}$ & $\begin{array}{l}14 \\
29\end{array}$ \\
\hline 123 & & & Det Udom & Amphoe Det Udom. & & $\mathrm{D}$ & 21 \\
\hline 124 & Sisaket & Muang - . & Phon Kho & Nai Net Worachinda & 1940 & $\mathrm{D}$ & 26 \\
\hline 125 & Ubon. & $\begin{array}{c}\text { Phibun } \\
\text { mang- } \\
\text { sahan }\end{array}$ & $\begin{array}{l}\text { Phibun mang- } \\
\text { sahan. }\end{array}$ & Amphoe Phibun & & $\mathrm{D}$ & 11 \\
\hline 126 & Sisaket & Muang-- & Muang Nua ... & Government office & 1929 & D & 27 \\
\hline $\begin{array}{l}127 \\
128\end{array}$ & -...-do do & $\ldots$ do do............... & Muang Tai... & Provincial hospital ... & $1950 \ldots$ & $\stackrel{D}{D}$ & $\begin{array}{l}25 \\
15\end{array}$ \\
\hline 129 & $\ldots d$ & . & Muang Nua... & Wat Phrato & 1924 & $\mathrm{D}$ & 23 \\
\hline 130 & d & do.............. & do & Police station. & 1944 & $\bar{D}$ & 18 \\
\hline 131 & ..... do & ................ & Muang Tai... & Electric plant.... & $1952 \ldots$ & $\mathrm{D}$ & 17 \\
\hline $\begin{array}{l}132 \\
133\end{array}$ & Ubon & Khuang Nai & & Public well. & 1949 & $\mathrm{D}$ & 20 \\
\hline 133 & ..... do & $\underset{\text { Kaew }}{\text { Kam Khuan }}$ & $\mathrm{L}$ & ......do. & & $\mathrm{D}$ & 15 \\
\hline $\begin{array}{l}134 \\
135\end{array}$ & Roi Et. & Yasothon & $\begin{array}{l}\text { Yasothon } \\
\text { Klang }\end{array}$ & Highways office & 195 & $\underset{D}{\mathrm{D}}$ & $\begin{array}{l}25 \\
25\end{array}$ \\
\hline 136 & .... do. & Thawatburi. & Ma Ue. & Nai Roi Sirathat. & 1934 & $\mathrm{D}$ & 20 \\
\hline 137 & do. & Muang...... & Nai Muang & Wat Klang. & $1924 \ldots$ & $\mathrm{D}$ & 29 \\
\hline 138 & & $\ldots . .$. do & ......do.. & Horse breeding statio & $1947 \ldots \ldots$ & $\mathrm{D}$ & 11 \\
\hline 139 & $-\ldots-40$ & do & ......do. & Public well & $1854 \ldots$ & $\mathrm{D}$ & 16 \\
\hline $\begin{array}{l}140 \\
141\end{array}$ & -....do... & .......do & _.....do......... & Nai Amphoe's house. & 1904 & D & 16 \\
\hline
\end{tabular}


in the Khorat Plateau-Continued

\begin{tabular}{|c|c|c|c|c|c|c|c|c|c|c|c|c|c|c|}
\hline \multirow[b]{2}{*}{ 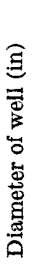 } & \multirow{2}{*}{ 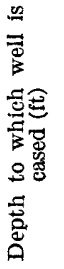 } & \multirow[b]{2}{*}{ 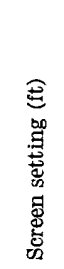 } & \multicolumn{3}{|c|}{$\begin{array}{l}\text { Principal water- } \\
\text { bearing bed }\end{array}$} & \multicolumn{2}{|c|}{ Water level } & \multirow[b]{2}{*}{ 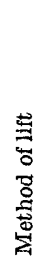 } & \multirow[b]{2}{*}{ 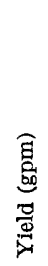 } & \multirow[b]{2}{*}{ 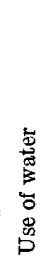 } & \multicolumn{4}{|c|}{ Quality of water } \\
\hline & & & 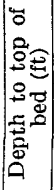 & 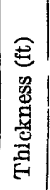 & 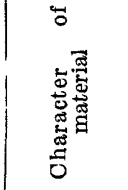 & 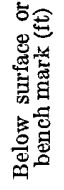 & 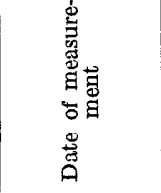 & & & & 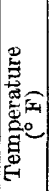 & 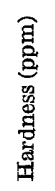 & 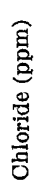 & 垔 \\
\hline 39 & 13 & & & & Shallow & 2 & & B & & $\mathrm{W}$ & 83 & 180 & 59 & 5.2 \\
\hline 57 & 23 & & & - & - & 11 & & B & & W & 79 & 384 & 350 & 6.7 \\
\hline 47 & 36 & & & -7 & ...... do . & 21 & Nov. 9,1954 & B & & W & 81 & 272 & 35 & 6.8 \\
\hline 79 & 37 & & & - & -do & 24 & _.do_ & B & & PS & 78 & 123 & 26 & 6.8 \\
\hline 59 & 31 & & & $-\ldots$ & $\ldots d c$ & 9 & do. & B & & PS & 81 & 44 & 32 & .8 \\
\hline 59 & 4 & & & $\ldots$ & -.-do & 34 & do & B & - & PS & 81 & 1 & 16 & 6.7 \\
\hline 39 & 27 & & & -..- & {$\left[\begin{array}{c}\text { do } \\
\hdashline\end{array}\right.$} & 13 & do & Cyl & 4 & $\begin{array}{l}\text { PS } \\
\text { PS }\end{array}$ & $\begin{array}{l}80 \\
81\end{array}$ & $\begin{array}{l}56 \\
60\end{array}$ & $\begin{array}{l}16 \\
20\end{array}$ & $\begin{array}{l}6.7 \\
6.7\end{array}$ \\
\hline 59 & 33 & & & $-\cdots$ & Fine- & 20 & Nov, 10,1954 & B & & $\mathrm{D}$ & 78 & 112 & 36 & 6.3 \\
\hline 59 & 33 & & & $-\cdots$ & Shallo & 25 & -do. & B & & PS & 81 & 120 & 17 & 7.0 \\
\hline 39 & 20 & & &.- & & 9 & do & B & & PS & 81 & 32 & 128 & 6. 7 \\
\hline 75 & 28 & & & $\ldots$ & (1) & 6 & do & B & & PS & 81 & 19 & 20 & 6.8 \\
\hline 6 & 30 & $30-40$ & $\ldots$ & $-\ldots$ & Sand. & 30 & Nov. 11,1954 & Cyl & 4 & $\mathbf{H}$ & 83 & 92 & 62 & 6.8 \\
\hline 6 & 10 & $10-25$ & -- & 1 & Sandy & 15 & -...do do & Cyl & 4 & PS & 86 & 18 & 32 & 5.5 \\
\hline 6 & 20 & $20-35$ & 15 & 60 & & & - do & Cyl & 4 & $\mathrm{~W}$ & 83 & 28 & 36 & 6.8 \\
\hline 47 & 22 & & $\cdots$ & $-\cdots$ & & 10 & - do & B & & PS & 80 & 40 & 48 & 5 \\
\hline 43 & 17 & & 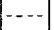 & $-\cdots$ & & 9 & do & B & 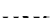 & H & & 1 & 4 & 6 \\
\hline $\begin{array}{l}39 \\
43\end{array}$ & $\begin{array}{l}22 \\
21\end{array}$ & & $\cdots$ & --- & & $\begin{array}{l}8 \\
9\end{array}$ & -.... do _ & $\mathrm{B}$ & --- & $\begin{array}{l}\text { PS } \\
\text { PS }\end{array}$ & 81 & 32 & $\begin{array}{r}190 \\
14\end{array}$ & 6.6 \\
\hline 43 & 21 & & & $\cdots$ & $\begin{array}{l}\text { Shallow - } \\
\text { sand. }\end{array}$ & 9 & -- & B & & PS & 80 & 2 & 14 & 6.7 \\
\hline 47 & 37 & & --- & --- & & 31 & .....do.. & B & $\cdots$ & PS & 84 & 24 & 73 & 6.7 \\
\hline 6 & 30 & $30-45$ & & & & & ...do & Cyl & 10 & $\mathrm{D}$ & 83 & & 4 & 6.9 \\
\hline 6 & 1 & $13-28$ & $\ldots$ & $\ldots$ & $\cdots$ & $\ldots$ & $\ldots$ & 1 & 6 & $\mathrm{PS}$ & & 5 & 10 & 3.7 \\
\hline 6 & 1 & $10-25$ & $\cdots$ & $\cdots$ & $-\cdots$ & $\ldots$ & $\ldots d$ & 1 & 10 & $\mathrm{P}$ & & 1 & & \\
\hline 6 & 25 & $25-40$ & $-\cdots$ & $\cdots$ & & & 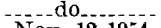 & Cyl & 10 & & 0 & 16 & 15 & 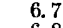 \\
\hline 59 & 39 & & $-\ldots$ & $-\cdots$ & $\begin{array}{l}\text { Shallow } \\
\text { sand. }\end{array}$ & 34 & Nov. 12,1954 & Cyl & 6 & W & 81 & 7 & 154 & 6.8 \\
\hline 39 & 33 & & $-\cdots$ & -- & ...do...... & 25 & .....do. & $\mathrm{B}$ & & W & 83 & 7 & 2 & 6.8 \\
\hline $\begin{array}{l}59 \\
51\end{array}$ & $\begin{array}{r}14 \\
9\end{array}$ & & $\mid \cdots$ & $-\cdots$ & Fine- & $\begin{array}{r}7 \\
17\end{array}$ & - do do.... & $\begin{array}{l}\mathrm{B} \\
\mathrm{B}\end{array}$ &.- & $\begin{array}{l}\mathrm{PS} \\
\mathrm{PS}\end{array}$ & $\begin{array}{l}84 \\
79\end{array}$ & $\begin{array}{r}5 \\
412\end{array}$ & $\begin{array}{l}23 \\
12\end{array}$ & $\begin{array}{l}6.7 \\
6.7\end{array}$ \\
\hline & & & & & $\begin{array}{l}\text { grained } \\
\text { sand. }\end{array}$ & & & & & & & & & \\
\hline 47 & 21 & & $\ldots$ & & & 8 & 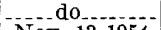 & B & & PS & 81 & 52 & 82 & 6. 7 \\
\hline 47 & 26 & & $-\ldots$ & & $\begin{array}{l}\text { Sand and } \\
\text { laterite. }\end{array}$ & 7 & Nov. & B & & PS & 82 & 80 & 8 & 6.7 \\
\hline 47 & 11 & & $\ldots$ & --- & & 5 & - & B & & W & 83 & 60 & 41 & 6.8 \\
\hline 59 & 2 & & --- & $-\cdots$ & Late & 19 & -... do & $\mathrm{B}$ & & PS & 83 & 5 & 93 & 7 \\
\hline 31 & 2 & & & $-\cdots$ & & 18 & ( & B & & H & & & 8 & \\
\hline 35 & 12 & & $\cdots$ & $\cdots$ & Red cl & 9 & $\ldots . . . d$ & Cyl & 7.5 & $\stackrel{\mathbf{I}}{\mathrm{PS}}$ & 83 & 1 & 40 & \\
\hline 51 & 2 & & $\cdots$ & $-\cdots$ & $\begin{array}{l}\text { Laterit } \\
\text { do }\end{array}$ & $\begin{array}{r}12 \\
9\end{array}$ & $\cdots d$ & $\begin{array}{l}\mathrm{B} \\
\mathrm{B}\end{array}$ & $\ldots$ & PS & 83 & 8 & $\underset{20}{126}$ & 6.5 \\
\hline 98 & 17 & , & 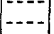 & $-\cdots$ & Sand and & 11 & do & $\mathrm{B}$ & & W & $\begin{array}{l}82 \\
76\end{array}$ & 96 & $\begin{array}{r}29 \\
122\end{array}$ & $\begin{array}{l}\text { b. } \\
6.5\end{array}$ \\
\hline 49 & 20 & & & & & 3 & Nov. & B & & PS & 83 & 16 & 22 & $\begin{array}{llll}7 & & \\
\end{array}$ \\
\hline 43 & 15 & & $=$ & & & 8 & $\cdots$ & B & & PS & 83 & 40 & 24 & 6.5 \\
\hline 47 & 25 & & $\cdots$ & & & 19 & $\ldots$...d & B & & & 84 & 16 & 1 & \\
\hline 47 & & & & & & 2 & S & B & & & & & & \\
\hline 5 & & & $\ldots$ & $-\ldots$ & $\ldots$ & 14 & & B & -- & & 80 & 216 & 15 & \\
\hline 8 & & & - & & & 18 & Nov. 15,1954 & B & & & & & 250 & \\
\hline 80 & 11 & & & & & 6 & ...do...... & B & $\cdots$ & W & 78 & 136 & 2 & $5-7$ \\
\hline 47 & if & & $\ldots$ & 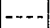 & $\cdots$ & 5 & .....do & B & $\ldots$ & 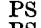 & 8 & 8 & 11 & \\
\hline 47 & 16 & & $\ldots$ & $\ldots$ & $\ldots$ & 4 & .... do & $\mathbf{B}$ & $\ldots$ & PS & 79 & 40 & 00 & 3. 5-7 \\
\hline 80 & 25 & & & & & 4 & & B & & 1 & 81 & 48 & 62 & $6-6.5$ \\
\hline
\end{tabular}


TABLE 2.-Records of wells

\begin{tabular}{|c|c|c|c|c|c|c|c|}
\hline & \multicolumn{3}{|c|}{ Location } & \multirow[b]{2}{*}{ Name } & \multirow[b]{2}{*}{ Date completed } & \multirow[b]{2}{*}{ 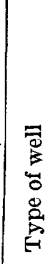 } & \multirow[b]{2}{*}{ 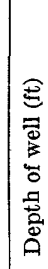 } \\
\hline $\begin{array}{l}\dot{0} \\
\dot{z} \\
\dot{z}\end{array}$ & Changwat & District & Tambon & & & & \\
\hline 142 & Mahasara- & Muang & Tha Tum..... & Nai On Panta Chum.- & 1934 & $\mathrm{D}$ & 19 \\
\hline $\begin{array}{l}143 \\
144\end{array}$ & $\begin{array}{l}. . . \mathrm{do} \\
\mathrm{do}\end{array}$ & do & Tha Lat & Municipal Well - & 1951 - & $\mathrm{D}$ & 30 \\
\hline 145 & do...... do & -...do-do & 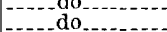 & Provincial Hospital. & $1952-$ & D & $\begin{array}{l}18 \\
19\end{array}$ \\
\hline & ...do & ....do & $\ldots \mathrm{do}_{2}$ & Municipal Well & 1950 & $\mathrm{D}$ & 14 \\
\hline $\begin{array}{l}147 \\
148\end{array}$ & -...do do & Borabu & Borabu & $\begin{array}{l}\text { Amphoe Borabu } \\
\text { Nai Swat Siriyotha. }\end{array}$ & $1949 \ldots \ldots$ & $\stackrel{D}{D}$ & $\begin{array}{r}10 \\
8\end{array}$ \\
\hline 149 & -.... do ..... & $\ldots$ do & ..... do & Nai Somphon Suwan- & 1947 & $\mathrm{D}$ & 17 \\
\hline 150 & Khon Kaen_ & Ban Phai .. & Ban Phai.. & Highways office & 1944 & $\mathrm{D}$ & 39 \\
\hline 151 & Surin.... & Muang... & Nai Muang.. & Nai Phichan Suchin- & 1924 & $\mathrm{D}$ & 16 \\
\hline 152 & -..... do & -...do.. & .... do & Nai Phachern Mikhanet.- & 1934 & $\mathrm{D}$ & 15 \\
\hline 153 & $\ldots$ & ...... do & ......... & Provincial kindergarten & 1941 & D & 23 \\
\hline 154 & $\ldots$ do....... & do_ & do & Nai Bua Chat Thong.-.-- & 1949 & $\mathrm{D}$ & 10 \\
\hline $\begin{array}{l}155 \\
156\end{array}$ & -..do do.... & ....do do & -.....do- & Nang Kuren Thanabun & 1904 & $\mathrm{D}$ & 6 \\
\hline $\begin{array}{l}157 \\
158\end{array}$ & .... do & $--u$ & $\ldots$ do & Military rest house- & 1944 & $\mathrm{D}$ & 8 \\
\hline & 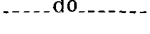 & & 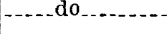 & Provineial boys school_ & 1940 & D & 10 \\
\hline
\end{tabular}


in the Khorat Plateau-Continued

\begin{tabular}{|c|c|c|c|c|c|c|c|c|c|c|c|c|c|c|}
\hline \multirow[b]{2}{*}{ 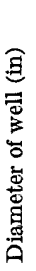 } & \multirow{2}{*}{ 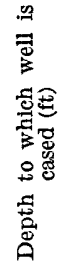 } & \multirow[b]{2}{*}{ 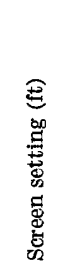 } & \multicolumn{3}{|c|}{$\begin{array}{l}\text { Principal water- } \\
\text { bearing bed }\end{array}$} & \multicolumn{2}{|c|}{ Water level } & \multirow[b]{2}{*}{ 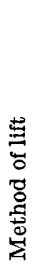 } & \multirow[b]{2}{*}{ 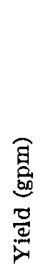 } & \multirow[b]{2}{*}{ 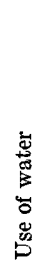 } & \multicolumn{4}{|c|}{ Quality of water } \\
\hline & & & 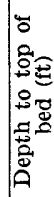 & 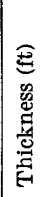 & 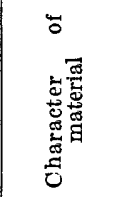 & 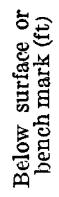 & 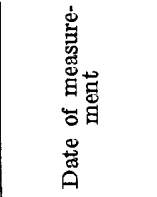 & & & & 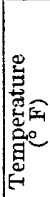 & 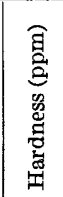 & 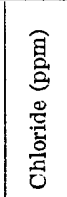 & 要 \\
\hline 86 & 19 & & & & & 9 & Nov. 15,1954 & B & & PS & 82 & 5 & 14 & 6.5 \\
\hline 39 & 30 & & - & & & 22 & do. & B & & $\mathrm{W}$ & 81 & 1,150 & 1,120 & $6.5-7$ \\
\hline 47 & 18 & & & & & 5 & do & B & & PS & 82 & & 159 & \\
\hline 43 & 19 & & $\ldots$ & $\ldots$ & & 12 & . do & B & & $\mathbf{H}$ & 83 & 120 & 103 & \\
\hline $\begin{array}{r}39 \\
30\end{array}$ & 14 & & $\cdots$ & $\ldots$ & ---1 & 5 & do do & B & & PS & 82 & 24 & 8 & $6-6$ \\
\hline 39 & 10 & & -- & $-\ldots$ & Won- & 4 & Nov. 16,1954 & :B & & $W$ & 80 & 4 & & 6. 5 \\
\hline 67 & None & & -- & $\ldots$ & $\begin{array}{l}\text { Fine- } \\
\text { grained } \\
\text { sand. }\end{array}$ & 6 & $\ldots \mathrm{do}$ & B & & PS & 79 & 16 & 20 & 6. $5-7$ \\
\hline 35 & 17 & & & $\cdots$ & 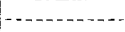 & 6 & do & B & & PS & 80 & 64 & 120 & 6. 5 \\
\hline 39 & 39 & & & - & Shallow & 18 & Nov. $14,19.54$ & $\mathbf{B}$ & & $\mathrm{W}$ & --- & 600 & 174 & 6. 5-7 \\
\hline 59 & None & & & $-\infty$ & Sand & 9 & _._. do & B & & $\mathrm{W}$ & 79 & 600 & 493 & 7 \\
\hline 31 & 15 & & & $\ldots$ & clayy and & 9 & $\ldots$ & B & & W & 81 & 400 & 348 & 7 \\
\hline 39 & 23 & & & $\ldots$ & Sandy & 5 & do. & B & & PS & 80 & 96 & 24 & 6. $5-7$ \\
\hline 60 & None & & & & Clay and & 5 & $\ldots \mathrm{do}$ & B & & PS & 79 & 5 & 25 & 6. $5-7$ \\
\hline 39 & & & &.--4 & $\ldots$. d & 5 & $\ldots$ do & B & & PS & 79 & 8 & 8 & 5 \\
\hline 67 & None & & & $-\ldots$ &.$--d o$ & 6 & Nov. 15 & B & & $\mathrm{PS}$ & 88 & 2 & 6 & \\
\hline 59 & None & & & 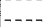 & do & 5 & _....do._ & B & & $\mathrm{D}$ & 80 & 16 & 49 & 6. $5-7$ \\
\hline $3 y$ & 10 & & & 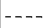 & _. do & 4 & ..... do & B & & $\mathrm{P}=$ & 83 & 13 & 19 & $6-6 . i$ \\
\hline
\end{tabular}




\section{INDEX}

Abstract...
Alluvium, character of
location of deposits
water from
Altitude of the area.
Arphoes. also individual amphoes.

Artesian conditions

Ban Phai, Amphoe, water supply for

Basalt, age of. lithologic character

Bua Yai, driller's log for test hole at. monthly rainfall at.

Bunnag, Din, with Nitipat Jalichan and P. E. LaMoreaux, Geology.

Buriram, basalt flows near

Calcium in water

Changwats.

Chloride salts in water

Climate.

Cretaceous age, deposits of

Det Udom, Amphoe, water supply for

Dissolved minerals in water.

Drainage

Drilled wells.

Driller's logs.

Dug wells.

Evaporation rate

Field investigations.

Fluctuation of water levels in wells

Fluoride in drinking water

Geography

Geologic history.

Geology, by Nitipat Jalichan, Din Bunnag, and P. E. LaMoreaux..

Ground water, artesian conditions. occurrence potential recovery of

recharge.

recovery of.

relation to rainfall

source.

Hardness of water

Huai Kha Khang
Page

Huai Samran................................... 47

Huai Saning.................................... 47-48

Hydrogen-ion concentration................. 41

Hydrologic cycle. . . . . . . . . . . . . . . . . . . . . 27-28

Igneous rocks, of Tertiary age................ 26-27

Index map. . . . . . . . .

Introduction............. 2-6

Isoheytal maps............... 31-34

Jalichan, Nitipat, and Din Bunnag and P. E.

LaMoreaux, Geology........... 12-27

Jurassic age, deposits of .................. 14, 24-25

Kalasin, monthly rainfall at.............. 10, 31-34

Kanchanaburi series, lithologic characteristics. 15, 18 outcrops of .................... 18 water-bearing characteristics............... 15

Khon Kaen, monthly rainfall at........... 10, 31-34 water-supply for........................... 43

Khorat, driller's $\log$ for test hole at........... 25, 26 local water supplies......................... 42 monthly evaporation at............... 11, 31-34

Khorat basin ........................... 16

Khorat Plateau, artesian conditions in ....... 29-30 potential recovery of ground water........ 37-40 rainfall in ................. 30-36

Khorat series, age of Phra Wihan member........... 14, 21-22, 29-30 Phu Kadung member ................. 14, 19-21 Phu Phan member............... 14, 23-24, 29-30 Khuang Nai, Amphoe, public water supply for.................................. 46

LaMoreaux, P. E., with Nitipat Jalichan and Din Bunnag, Geology............ 12-27 Local supplies of water. . . ................ 42-48 Location . . . . . . . . . Lumphuk, Amphoe, public water supply for ${ }^{45-46}$

Mae Nam Khong ..................... 4, 8-9

Mae Nam Mun.............................. 8

Mahasarakham, municipal water supply for-- $\quad 46$

Maps of Thailand ............ 7

Mukdahan, Amphoe, public water supplies.. $\quad 45$

Nakhon Phanom, Amphoe, public water supplies................................ 45

Nakhon Phanom, monthly rainfall at . . . 11, 31-34 Nakhon Ratchasima. See Khorat.

Nam Chi................................... 8

Nam Kam . . . . .

${ }_{46}$ Nam Songkhram. 8 
Nong Han, public water supply spring at.

Nong Khai, monthly rainfall at public water supply

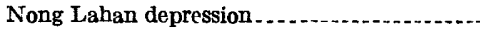

Nong Yama

Permeability.

Pha Nok Khao

Phanom Dang Raek

Phibun, Amphoe, water supply for

Phimai, water supply for

Phra Wihan member of Khorat series, artesian water in

lithologic character

outcrops

Phu Kadung, member of Khorat series, lithologic character.

14, 19-21

outerops... 20-21

water-bearing chracteristics.

Phu Phan member of Khorat series, artesian water in

lithologic character. 29-30

outerops

water-bearing character

Phu Phan range.

Physiographic provinces

Piezometric surface, depression of

Political divisions.

Population

Porosity

Previous investigations

Purpose.

Quality of water.

Quaternary deposits

14, 23-24

Rainfall.

Rat Buri limestone, lithologic character . . . 15, 18-19 water-bearing characteristics.............. 15

Recharge to ground water, by rainfall. .... 30-35, 38 by streams.............................. 35-36, 45

Records of wells .......................... 52-59

Recovery of ground water, methods......... 36 potential sources for ......................... 37-40

References ................................... 50-51

Rock units, sequence of................. 14-15, 16-17

Roi Et, monthly rainfall at_................. 10, 31-34 municipal water supplies at
Sakhon Nakhon, public water supply

Sakhon Nakhon basin........................ 16

Sandstone beds, age of .............. 18-19, 24-25

water from. ............................. 39-40

See also Kanchaburi series and Khorat series.

Scope of the investigation................... $3-4$

Sisaket, montbly rainfall at ................ 10.31-34

public water supply for.................. 47

Soil, relation to water storage................ $\quad 35$

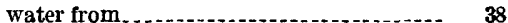

Specific capacity of wells, definition........... $\quad 36$

Springs......................... 37, 44

Stratigraphic sequence, table of :........ 14-15

Structural features

Summary ....

Surin, monthly rainfall at. .

public water supply for.................... 47-48

Temperature.................................. 9

Terrace deposits................................. 27

Tertiary rocks................. 26-27

That Phanom, Amphoe, public water supply. $\quad 45$

Thawatburi, Amphoe, water supply for -... 45-46

Topography ................. 8

Transportation. .............................. 12

Triassic rocks, description. . .................. 19-24 outcrops of

Types of wells ........... $36-37$

Ubon, monthly rainfall for............... 10, 31-34, 35 public water supply...................... 45

Udon Thani, monthly evaporation............ 11 monthly rainfall at ...................... 11,31-34 municipal water supply for...............- 43-44

Water, circulation of........................... 27-28

Water levels in wells, fluctuation of ..... 30,35-36 recovery of ............................. 36

Water table, definition....................... 28 depression of.............................. $\quad 36$

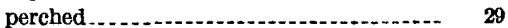

Water-table wells............................. 29

Wat That Phanom, well at ............ $\quad 29$

Wells, bored.......................................... 36-37

driller's logs for ................................ 25-26

dug ....................................... 36

records of

specific capacity -........................... 36

47 Yasothon, Amphoe, public water supply for.. 45-46 


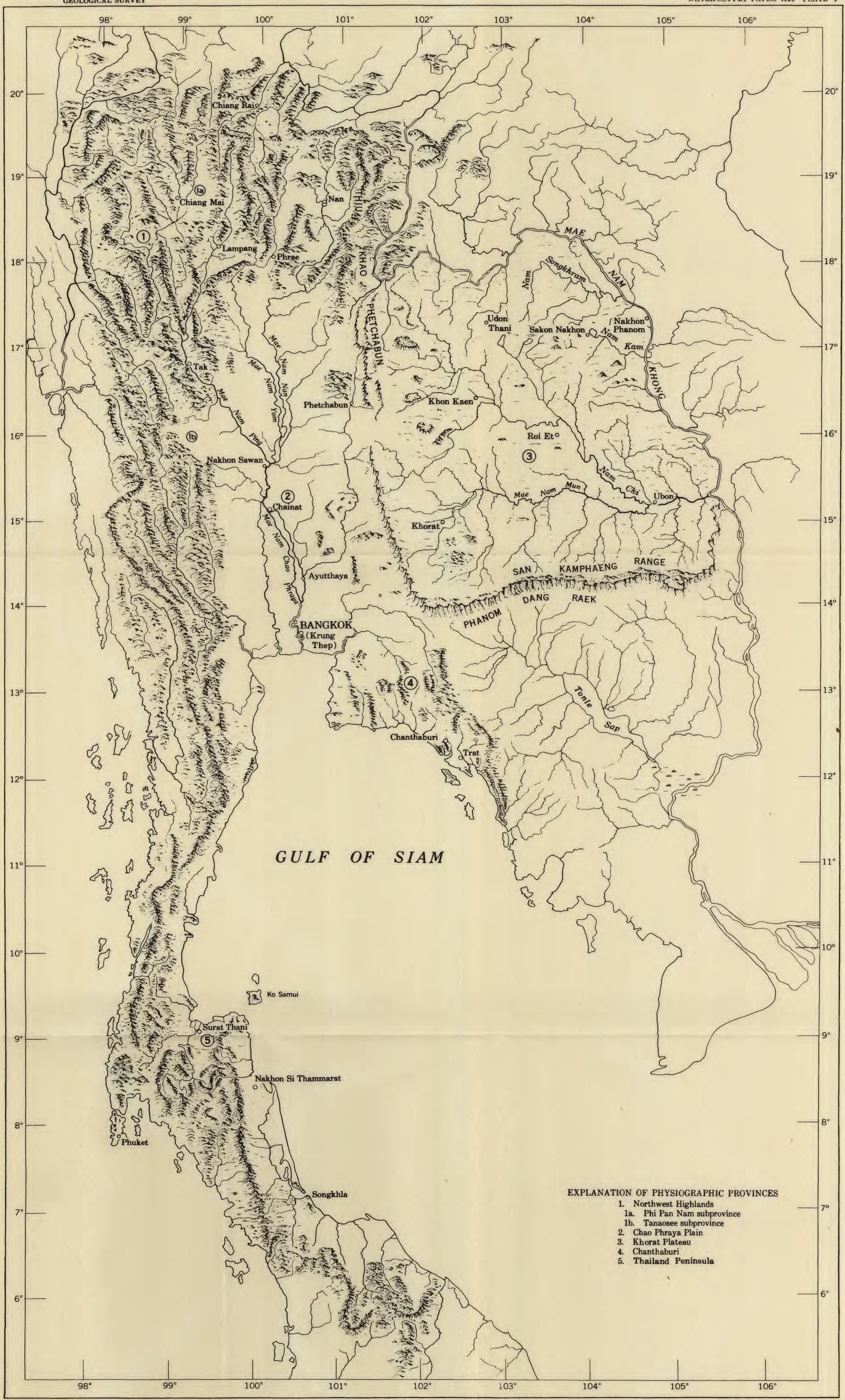



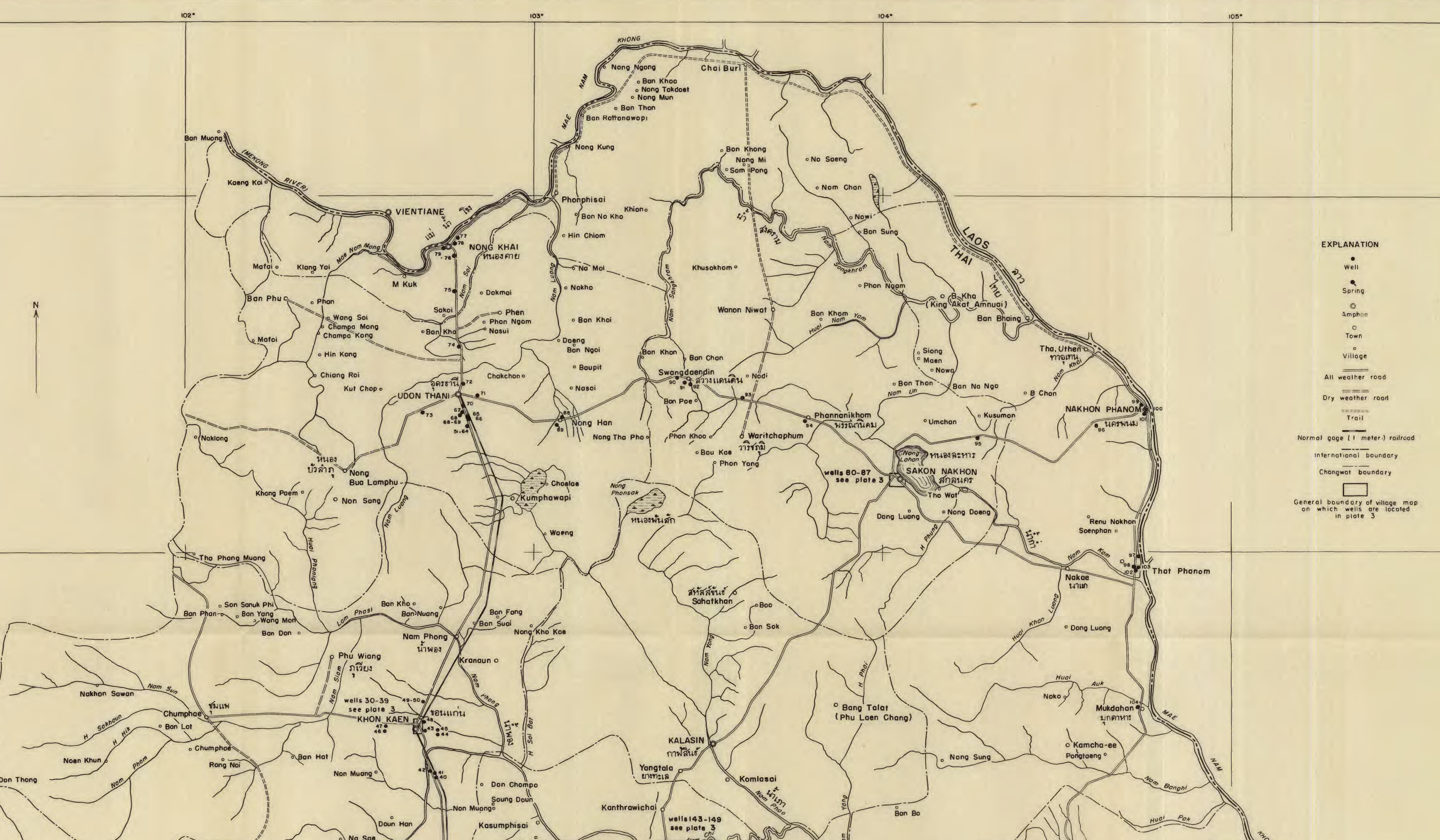

(1)

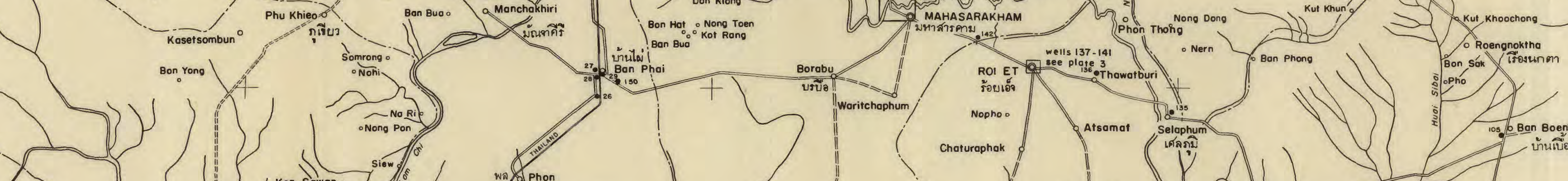
(n)
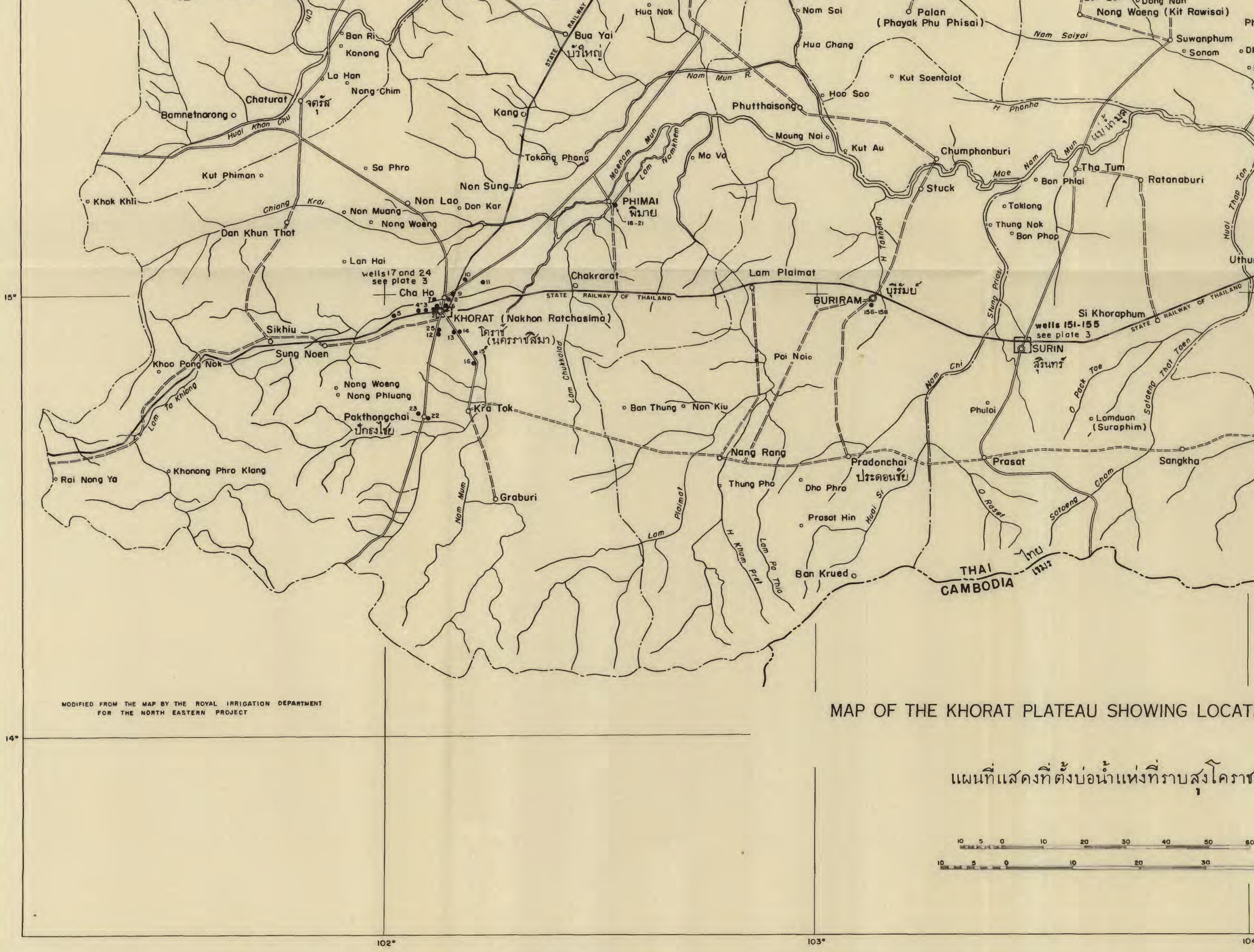


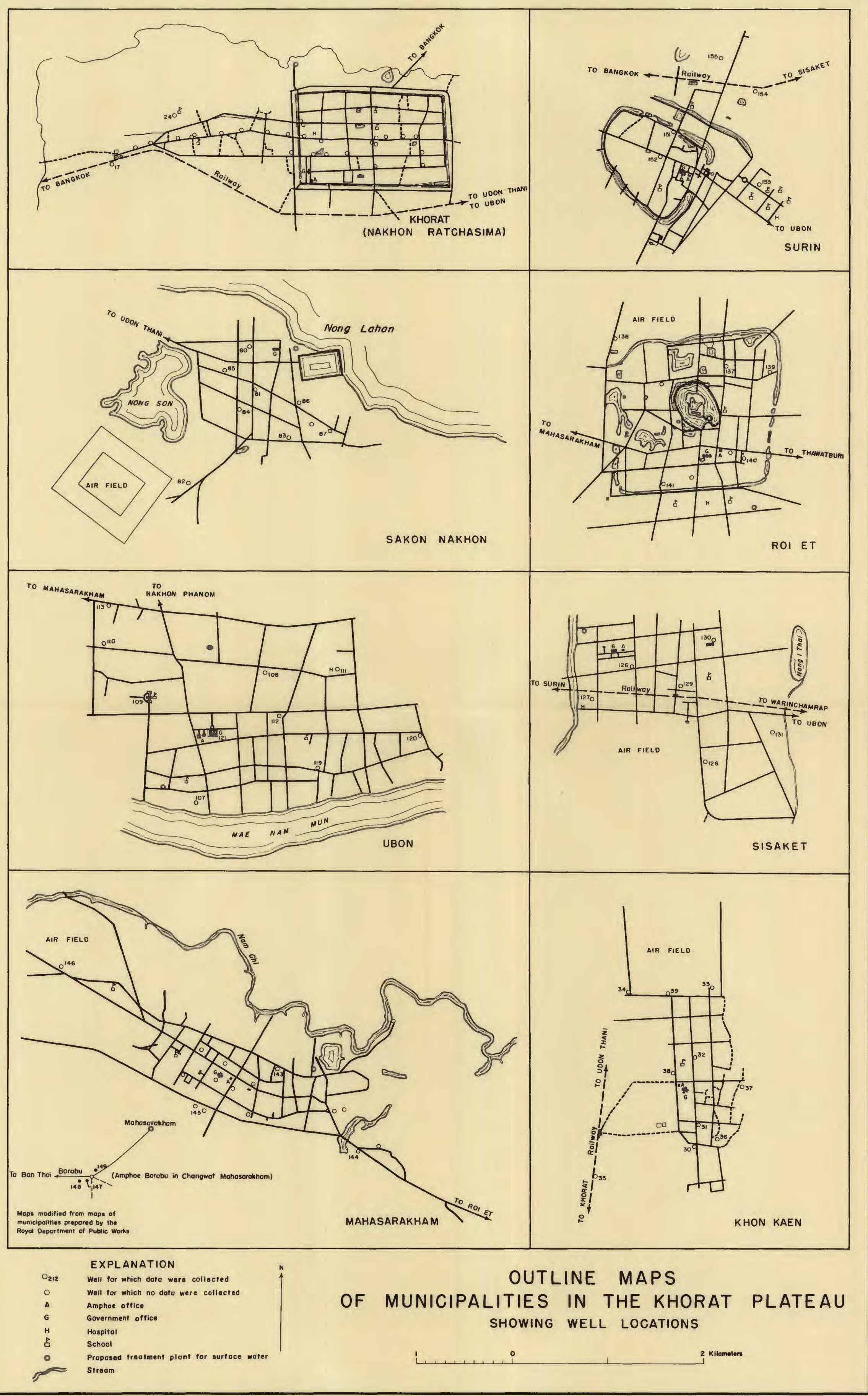




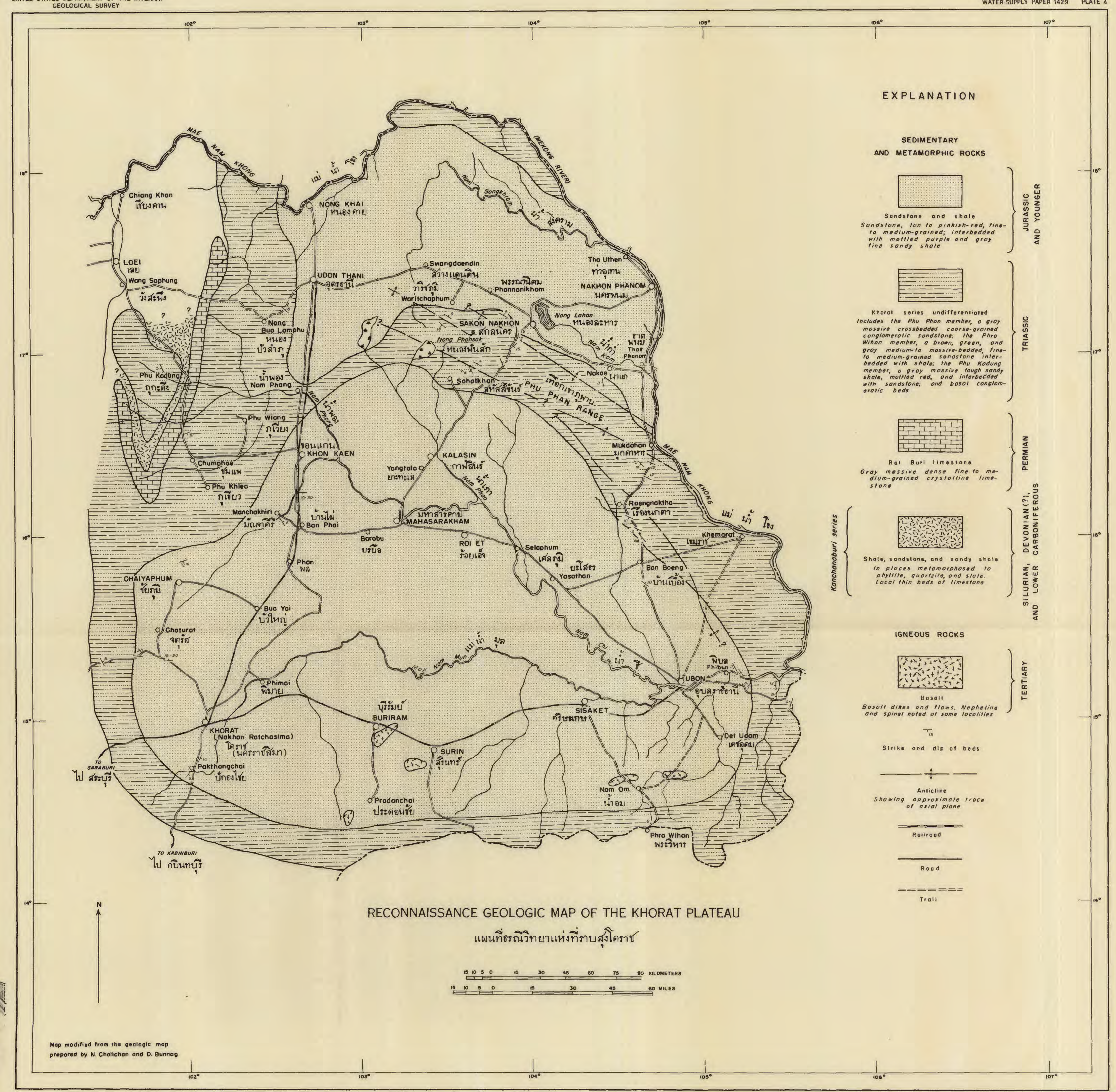

